\title{
قضايا تربوية في فكر الأمام الصادق (ع)- دراسة تحليلية تاريخية
}

أ.د. صالح مهدي عباس

مركز احياء التراث/ جامعة بغداد

أ.م.د. زهير عبد المجيد الخواجه احيه

كلية الطوسي الجامعة/ النجف الأثرف

المقدمة:

لقد خلق الله الإنسان وزوّده بعنصري العقل والإرادة ، فبالعقل يبصر ويكتشف الحقّ ويميّزه عن الباطل،

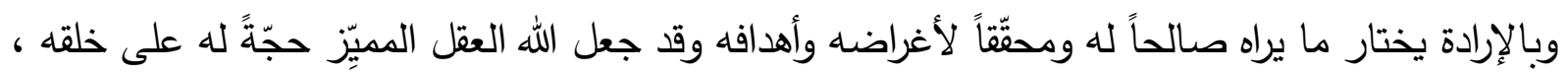

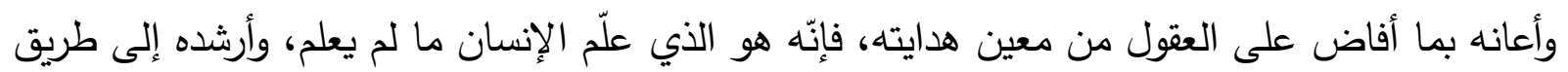

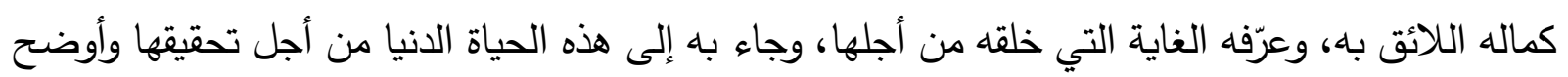

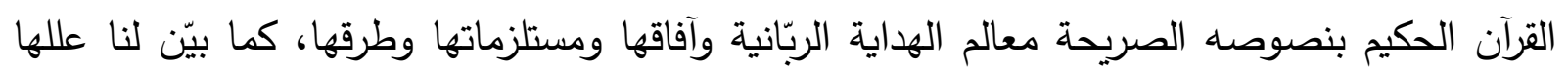
وأسبابها من جهة ، وأسفر عن ثمارها ونتائجها من جهة أُخرى.

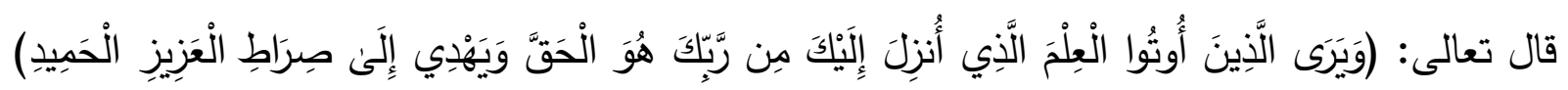

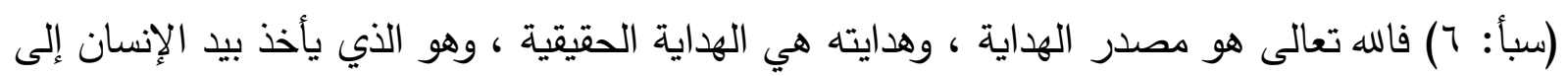

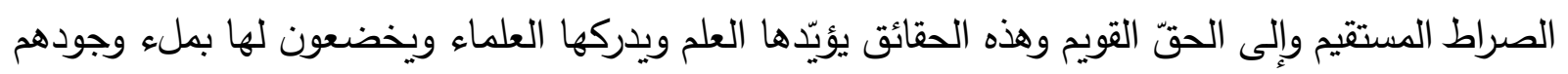

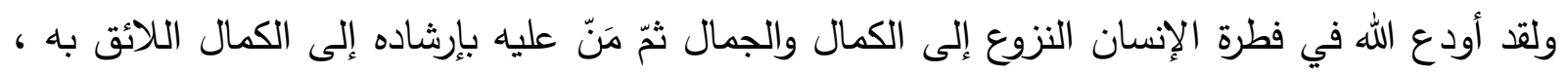

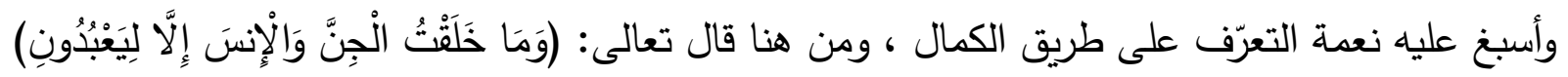
(الذاريات: به). وحيث لا تتحقّق العبادة الحقيقية من دون المعرفة، كانت المعرفة والعبادة طريقاً منحصراً

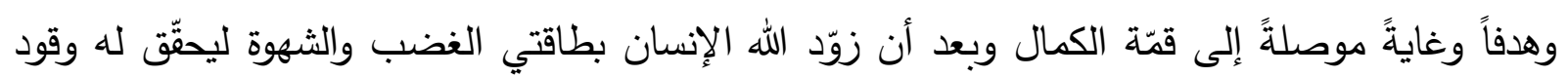

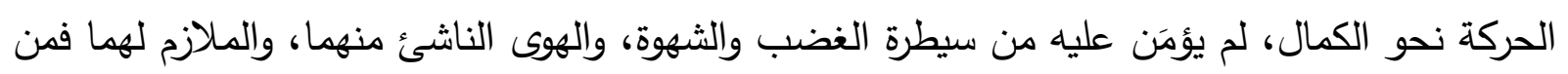


هنا احتاج الإنسان ـ بالإضافة إلى عقله وسائر أدوات المعرفة إلى ما يضمن له سلامة البصيرة والرؤية،

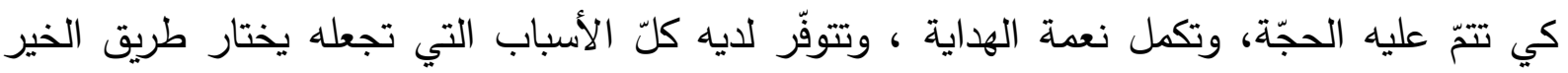

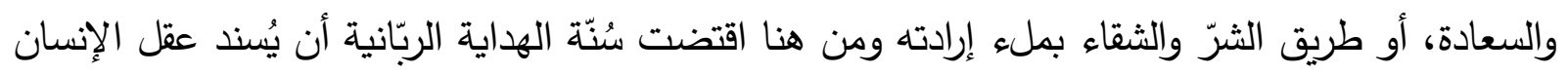

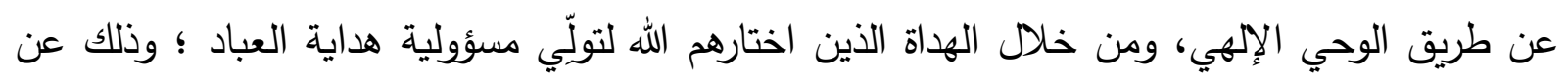
طريق توفير تفاصيل المعرفة وإعطاء الإرشادات اللازمة لكلّ مرافق الحياة وقد حمل الأنبياء وأوصياؤهم

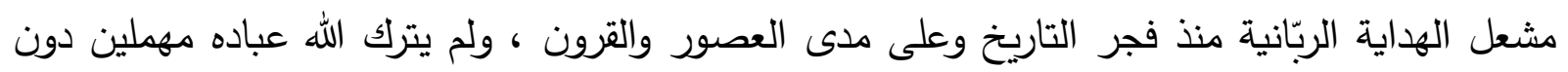

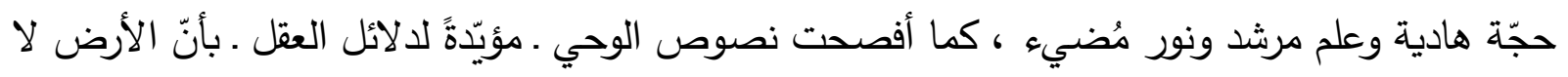

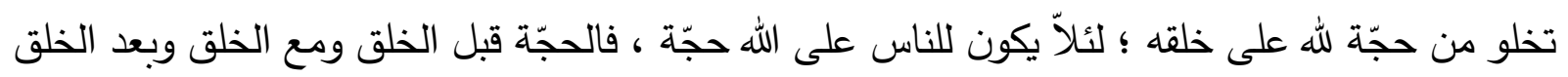

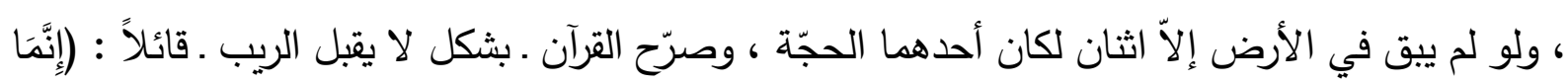

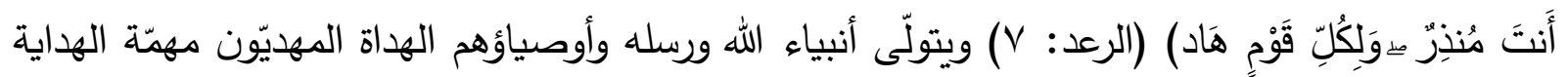
بجميع مراتبها، والتي تتلخّص في صيانة الرسالة من الزيخ والتحريف والضياع في الفترة المقرّرة لها، وهذه المهمّة أيضاً تتطلّب الكفاءة العلمية والنفسية ، والتي تسمّى بالعصمة والعمل لتحقيق أهداف الرسالة المعنوية وتتثيت القيم الأخلاقية في نفوس الأفراد وأركان المجتمعات البشرية ؛ وذلك بتنفيذ الأطروحة الربّانية ،

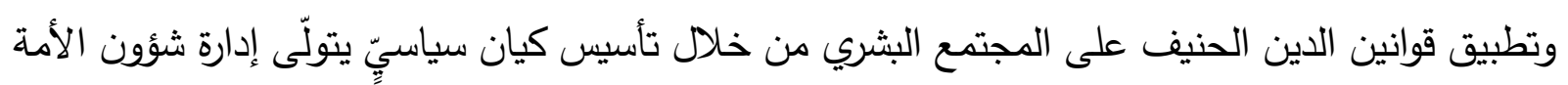

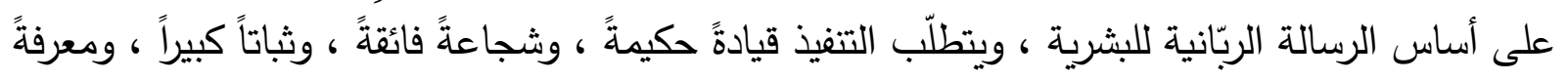

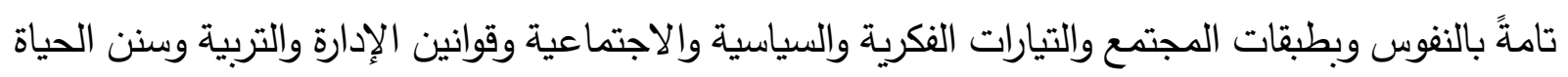
، ونلخّصها في الكفاءة العلمية لإدارة دولة عالمية دينية ، هذا فضلاً عن العصمة التي تعبّر عن الكفاءة

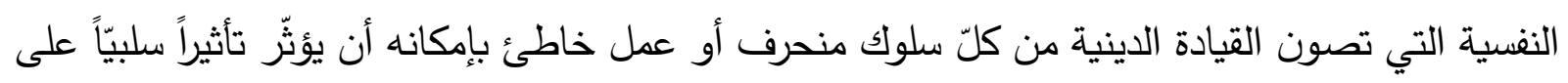

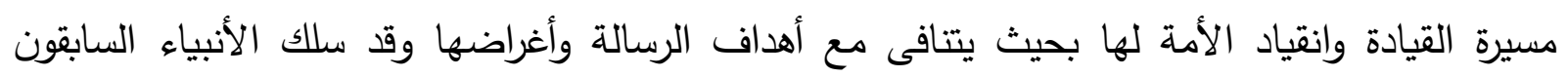

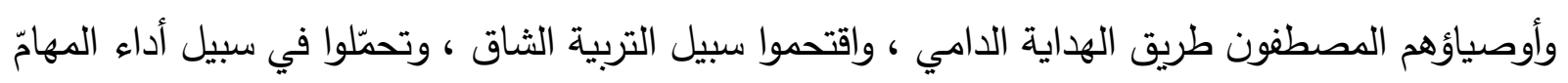


الرسالية كلّ صعب، وقدّموا في سبيل تحقيق أهداف الرسالات الإلهية كلّ ما يمكن أن يقدّمه الإنسان المتفاني في مبئئه وعقيدته ، ولم يتراجعوا لحظة ، ولم يتلكّأوا طرفة عين وقد توّج الله جهودهم وجهادهم

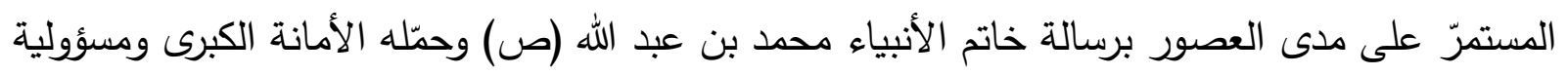

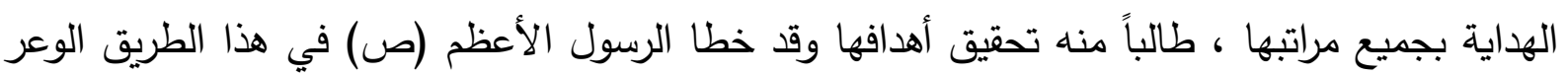
خطوات مدهشة، وحقّق في أقصر فترة زمنية أكبر نتاج مدكن في حساب الدعوات التغييرية والرسالات الثورية، وكانت حصيلة جهاده وكدحه ليل نهار خلال عقدين من الزمن في تقديم رسالة كاملة للبشرية

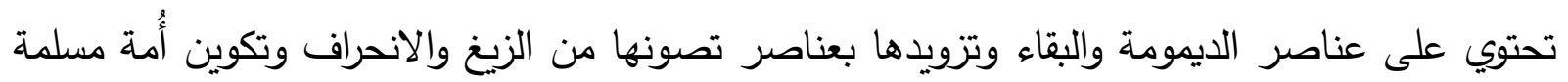

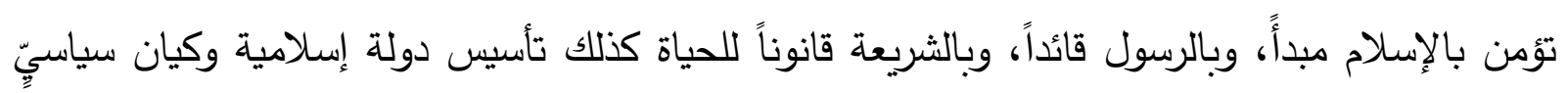
يحمل لواء الإسلام ويطبّق شريعة السماء من خلال تقديم الوجه المشرق للقيادة الربّانية الحكيمة المتمثّة

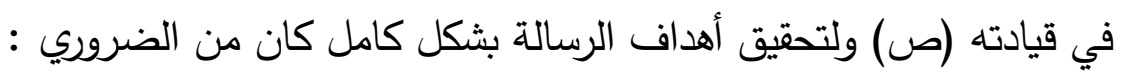

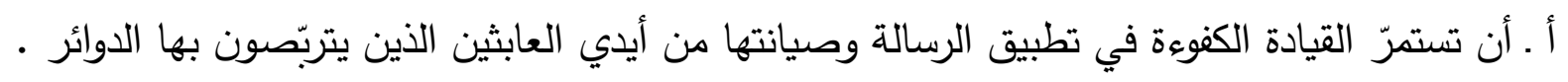

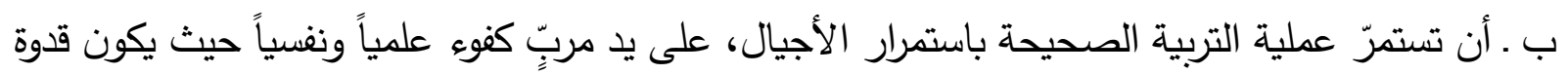
حسنة في الخلق والسلوك كالرسول (ص) ، يستوعب الرسالة ويجّّدها في كل حركاته وسكناته. ومن هنا كان التخطيط الإلهيّ يحتّم على الرسول (ص) إعداد الصفوة من أهل بيته، والتصريح بأسمائهم

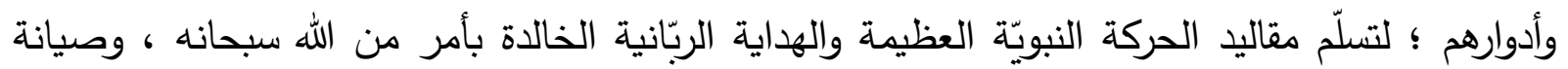

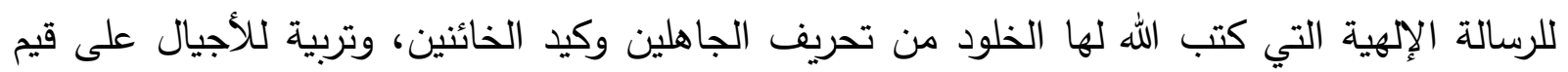

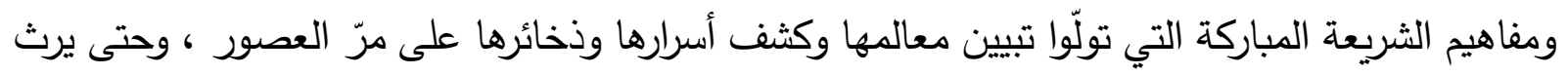

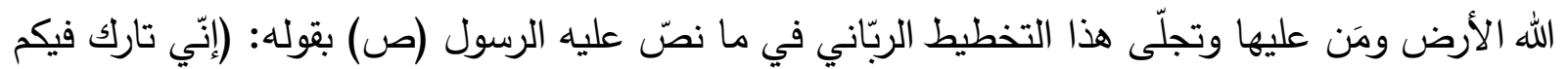

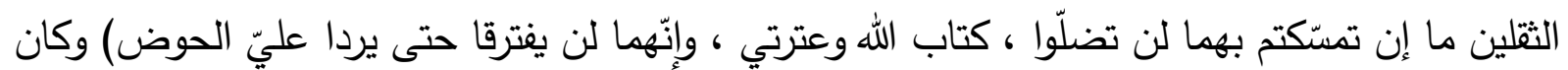

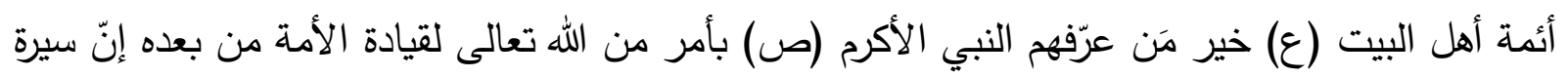


الأئمّة الاثني عشر من أهل البيت (ع) تمثّل المسيرة الواقعية للإسلام بعد عصر الرسول (ص)، ودراسة

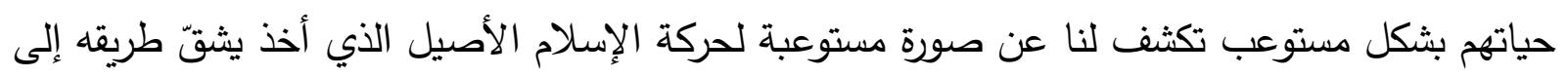

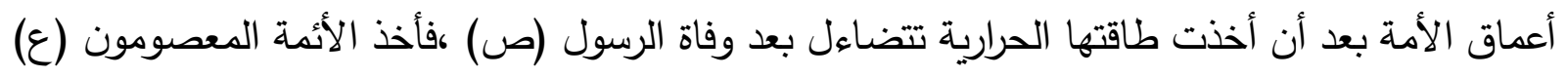
يعملون على توعية الأمة وتحريك طاقتها باتجاه إيجاد وتصعيد الوعي الرساليّ للشريعة ولحركة الرسول

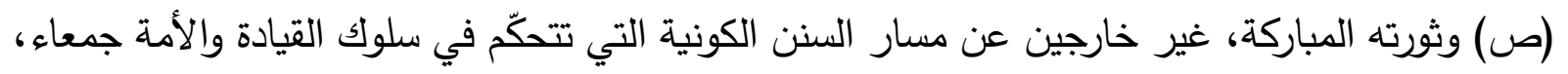

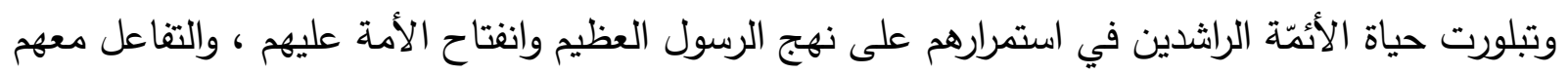
كأعلام للهداية ومصابيح لإنارة الدرب للسالكين المؤمنين بقيادتهم ؛ فكانوا هم الأدلاّه على الله وعلى الله مرضاته ، والمستقرين في أمر الله ، والتامّين في محبّته ، والذائبين في الثوق إليه ، والسابقينين إلى إلى تسلّق

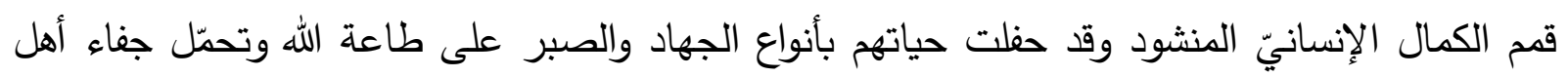
الجفاء حتّى ضربوا أعلى أمثلة الصمود لتنفيذ أحكام الله تعالى ، ثم اختاروا الثهادة مع التِّزّ على على الحياة مع الذّّ ، حتى فازوا بلقاء الله سبحانه بعد كفاح عظيم وجهاد كبير ولا يستطيع المؤرّخون والكتّاب أن يلمّوا

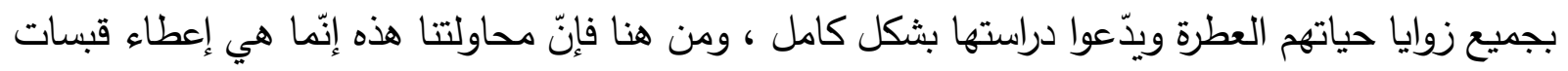

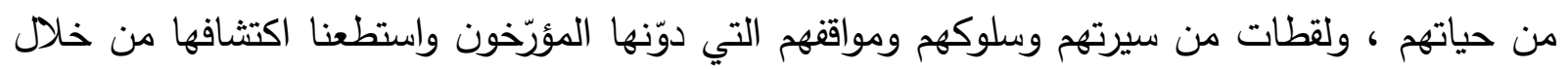

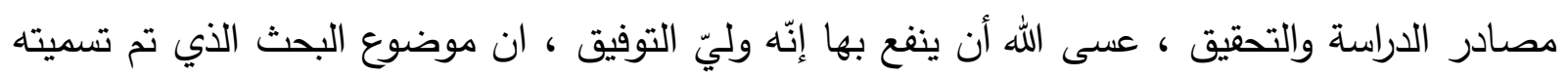

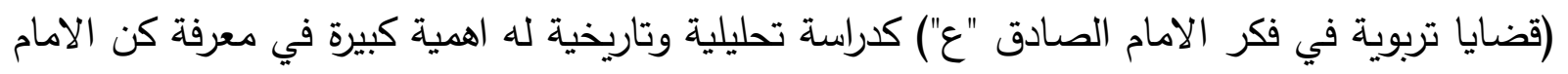
في تلك السطور المتواضعة كما ان دراسة البحث احتوت على مقدمة بديباجة راجية ان تليق بمقام مؤسس

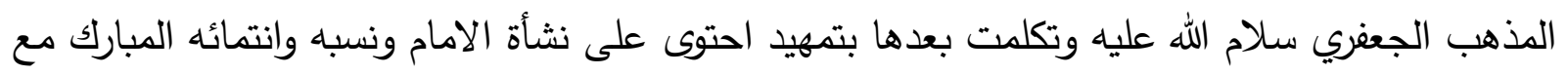

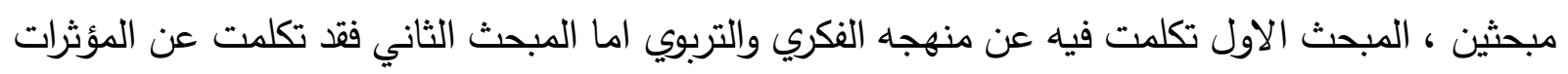
التربوية في نهاية العصر الاموي وبداية العصر العباسي وما جرى له ابان حكم المنصور الدوانيقي حتى في 
استثهاده (ع) حيث انتهيت بأهم ما توصلت اليه عبر خاتمة لموضوع البحث مع قائمة بأهم المصادر والمراجع التي اعتمدت عليها كما لا اخفي ان المصادر حول السيرة العطرة لأهل البت (ع). المنهج لغة واصطلاحا: المنهج : لغةً يعني الطريق الواضح وورد في القرآن الكريم في قوله تعالى ( لكل جعلنا منكم شرعة ومنهاجاً)

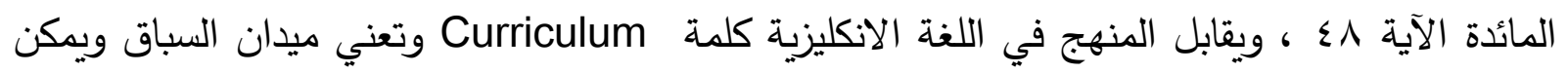

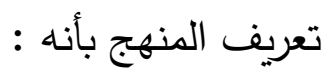
(الطريق الذي يسلكه المعلم والمتعلم للوصول إلى الأهداف المنشودة)، ولكن في ضوء الاتجاهات التربوية

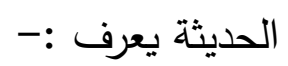

مجموع الخبرات التربوية المقصودة والمخططة من قبل المدرسة لإحداث النمو الثامل للطلبة بجميع النواحي

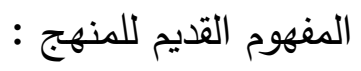
وهذا المفهوم يستمد مقوماته من الفكر القديم للتربية الذي يحدد أهدافها بالتركيز على الجانب العقلي للمتعلم

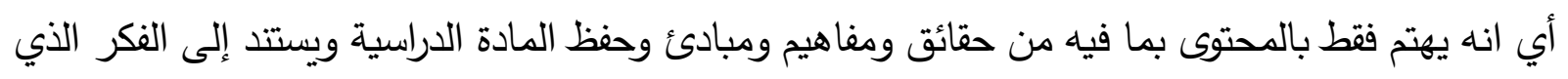

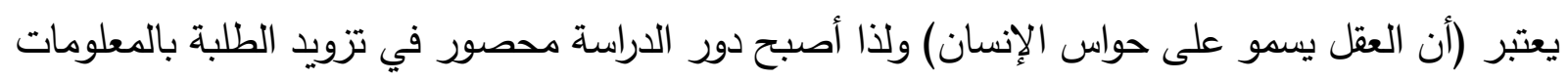

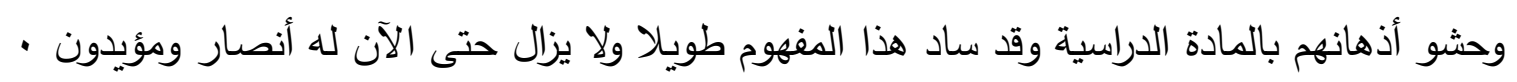

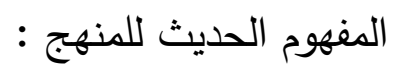
جاء المفهوم الحديث للمنهج كرد فعل للمفهوم القديم والتقليدي للمنهج ، وبدأ بدعوات من المربين وفلاسفة

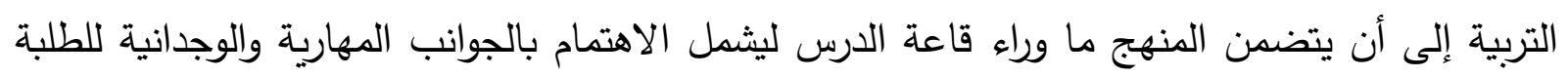

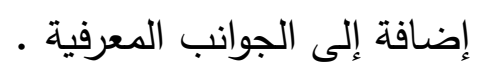
لذا فان احد التربويين يعرف المنهج الحديث بأنه : 
(كل الخبرات التي يكتسبها الطالب تحت إشراف المدرسة وتوجيهها سواء كان داخل الصف أو خارجه) وفي

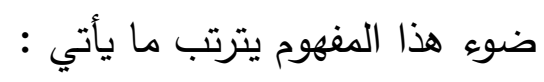
لم يعد الاهتمام متحددا بالناحية المعرفية بل يراعي المفهوم الحديث للمنهج الجوانب المهارية والثقافية

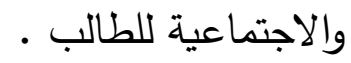
لم تعد المادة العلمية هدفاً بحد ذاتها وإنما أصبحت وسيلة تساعد في تحقيق عملية نمو الطالب . المدرسة أصبحت هنا جزء من المجتمع فهي تنسق جهودها مع البيت والمؤسسات الأخرى لغرض بنداء الطالب بناءً متكاملاً . تحرر المدرس من المنهج الضيق الذي يحدده في مجال واحد وأصبح دوره توجيهي وإرشادي ومساعد للطالب في تنمية قدراته المختلفة . الحياة المدرسية في ظل هذا المنهج حياة مشوقة ومحبوبة للطالب وتساعده في تكوين شخصيته وتتمية معارفه وقدراته . مانداه

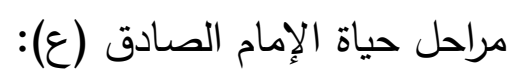

ولد الإمام جعفر بن محمد الصادق (ع) في مرحلة ازدهار الدولة الأموية حين ابتعد الخلفاء كثيراً عن طريق الحق وترسّخت صيغة الملك المتوارث . عاصر جدّه اثنتا عشرة سنة في المدينة وعاش مع أبيه بعد جدّه تسع عشرة سنة. نهل خلالها جميع العلوم والمعارف من أبيه (ع) وفاق الجميع بسعة إدراكه وشدة ذكائه . وشارك أباه محنة الصبر على تولّي الظالمين والتعرّض للبلاء كما ساهم مع أبيه في نشر العلوم الإسلامية من خلال حلقات الدرس التي أسّسها لكي لا تضيع الرسالة وتتدرس معالم الدين •

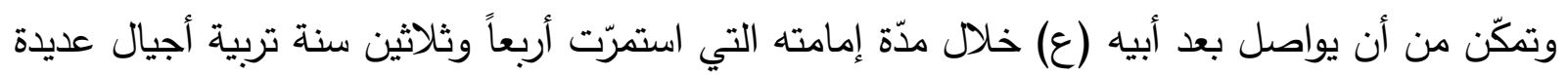

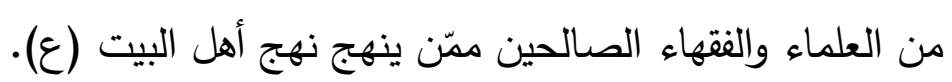


وكما عاصر الإمام الصادق (ع) مرحلة انحطاط الدولة الأموية وأفولها عاصر كنلك ظهور الدولة العباسية

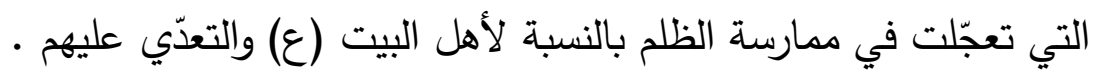
وتمكّن الإمام الصادق (ع) في هذه الفترة من المعترك السياسي المرير أن يحافظ على كيان المذهب الثيعي واستمرار سلامة الجماعة الصالحة وتتميتها، تلك الجماعة التي عمل على بنائها وتوسعتها آباؤه الطاهرون

انطباعات عن شخصية الإمام الصادق (ع):

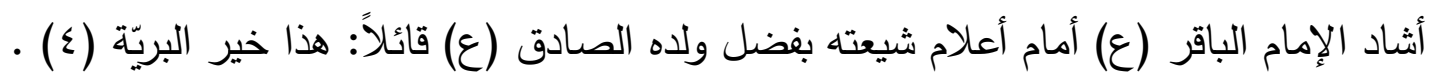

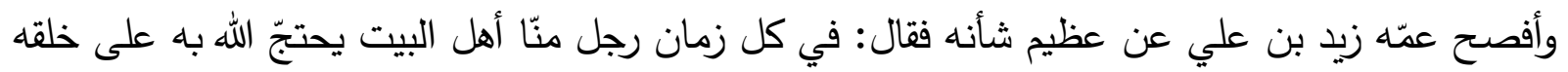

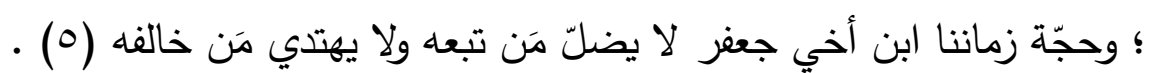

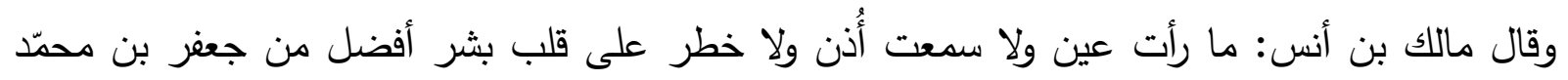

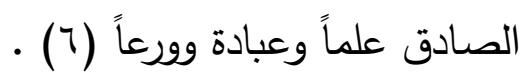

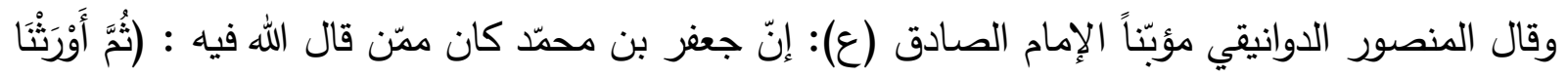

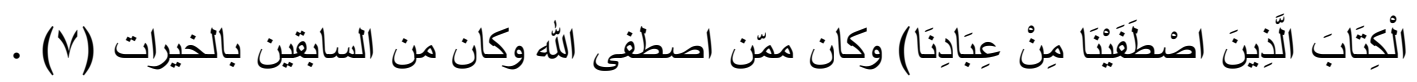


مظاهر من شخصية الامام الصادق (ع): سعة علمه:

لقد شقّق الإمام الصادق (ع) العلوم بفكره الثاقب وبصره الدقيق؛ حتَّى ملأ الدنيا بعلومه، وهو القائل: (سلوني قبل أن تفقدوني فإنّه لا يحدثكم أحد بعدي بمثل حديثي) (^) ولم يقل أحد هذه الكلمة سوى جدّه الإمام أمير

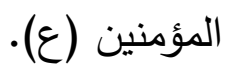
وأدلى (ع) بحديث أعرب فيه عن سعة علومه فقال: (والله إنّي لأعلم كتاب الله من أوّله إلى آخره كأنّه في

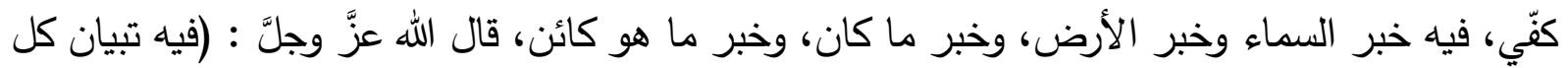

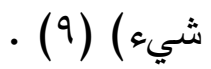
وقد كان من مظاهر سعة علمه أنّه قد ارتوى من بحر علومه أربعة آلاف طالب، وقد أشاعوا العلم والثقافة

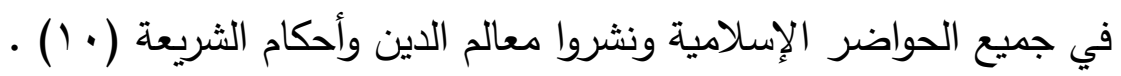
سمو أخلاقه : كان الإمام الصادق (ع) على جانب كبير من سمو الأخلاق، فقد ملك القلوب، وجذب العواطف بهذه

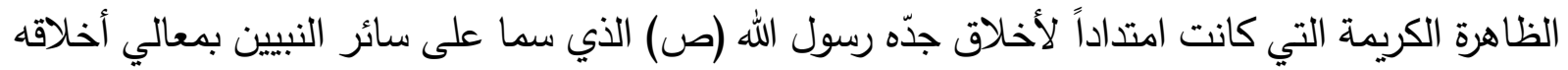

وكان من مكارم أخلاق الإمام وسمو ذاته أنّه كان يحسن إلى كل مَن أساء إليه، وقد روي أنّ رجلاً من

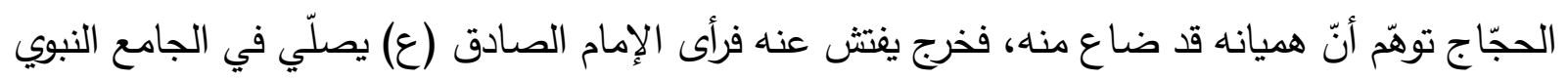

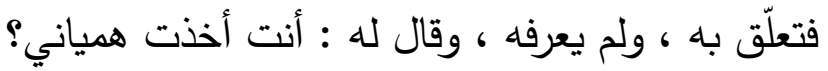

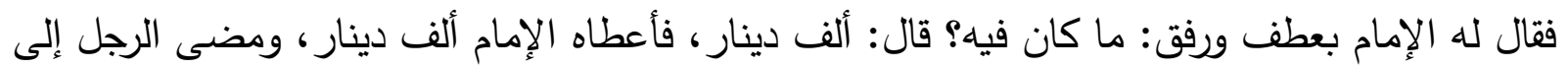

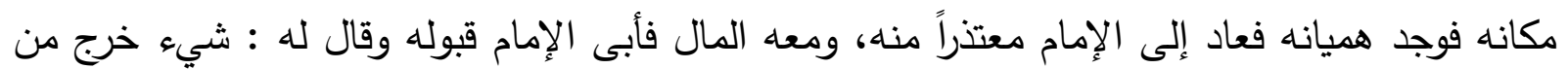


يدي فلا يعود إلي، فبهر الرجل وسأل عنه ، فقيل له : هذا جعفر الصادق، وراح الرجل يقول بإعجاب: لا

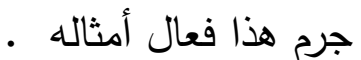

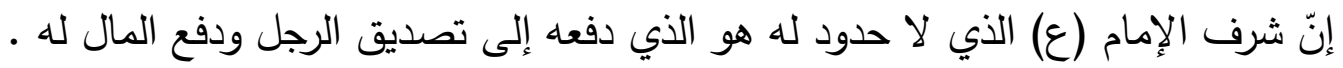
وقال (ع): إنّا أهل بيت مروءتنا العفو عمّن ظلمنا. وكان يفيض بأخلاقه الندية على حضّار مجلسه حتَّى قال رجل من العامة: والله ما رأيت مجلساً أنبل من

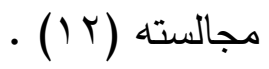

\section{المبحث الأول: قضايا تربوية في فكر الامام الصادق (ع):}

الاعداد التربوي العقائدي عند الامام الصادق (ع) ومتطلبات عصره ودوره في بناء الجماعة الصالحة

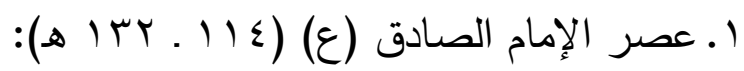

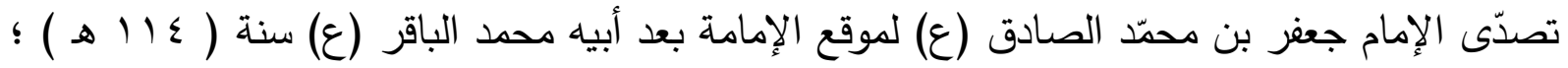

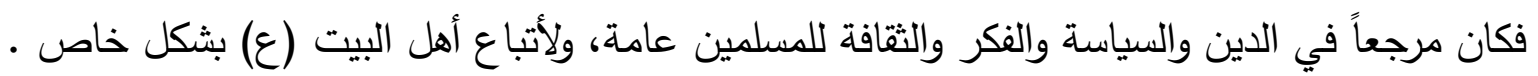
وهذا الأمر نجده واضحاً في جوابه لأبيه عندما أوصاه بصحابته وخاصّته. قال الإمام الصادق (ع): لمّا حضرت أبي الوفاة قال: يا جعفر أوصيك بأصحابي خيراً. قلت: (جعلت فداك والله لأدعنّه والرجل منهم

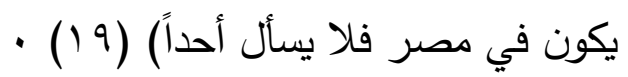
بهذا المستوى العالي من الإقدام الثجاع أعرب الإمام (ع) عن نواياه وبرنامجه الذي أعدّه لمستقبل الثيعة في ظل إمامته والخطّة التي تؤهّلهم لأن يكونوا ذلك النموذج السامي في المجتمع الإسلامي حيث يتحرّك كلٌ منهم برؤى واضحة المسار، بلا فوضى في الاختيار ولا ضلالة في الفكر والسلوك ؛ لأنّ هذا الإعداد

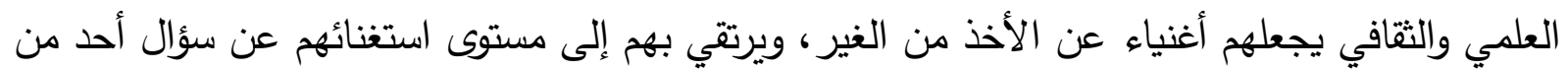

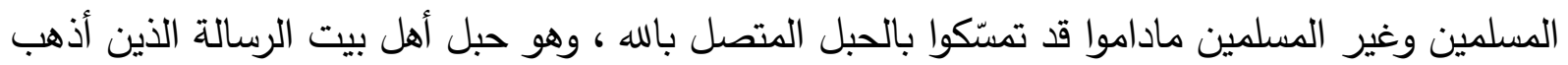
الله عنهم الرجس وطهّرهم تطهيراً . 
وكان الإمام الباقر (ع) قبل هذا الوقت قد هيّأ الثيعة وأعدّهم لأخذ معالم الشريعة من الإمام الصادق

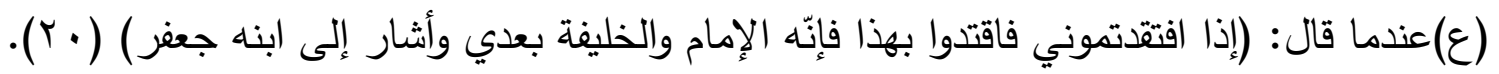

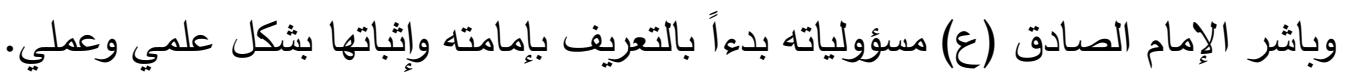

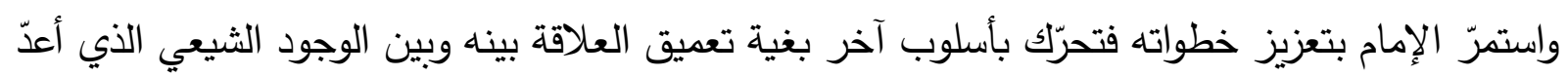
تفاصيله ورسم معالمه الإمام الباقر (ع). ومن هنا نجد الإمام الصادق (ع) يشحذ همهم ويشير في نفوسهم الحماس ويخاطب مواطن الخير والقوّة

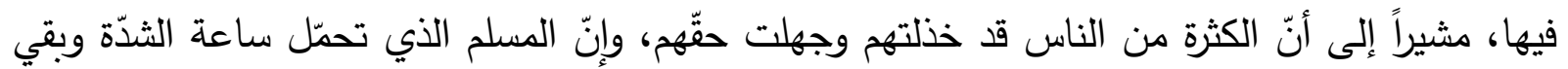
ملازماً لهم حتَّى صقلته التجارب ولم يستجب للإغراءات لهو جدير بحمل الأمانة ومواصلة الطريق معهم.

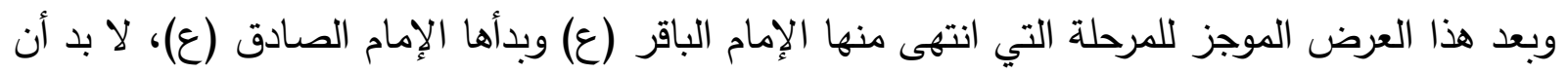

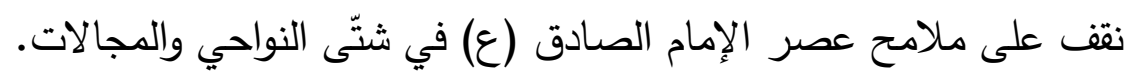
اولا: الوضع السياسي وأثره على القيم التربوية:

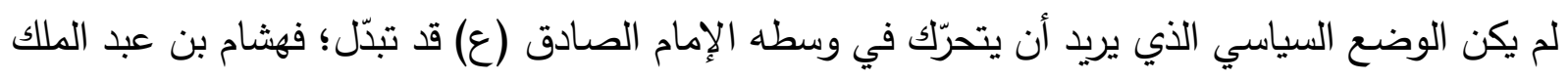

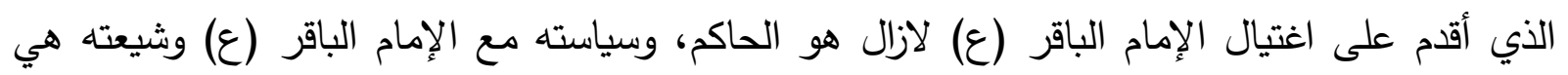

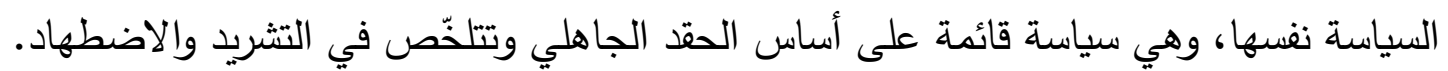

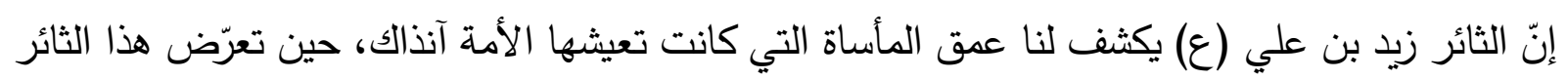
العظيم في زمن الإمام الباقر (ع) لإذلال وتوهين من قِبل هشام باعتباره أحد رجال الثيعة ومن رموزها • البارزين أخذ زيد يزداد قناعة بضرورة الثثرة ضد الأمويين حتى صمّم على ذلك بلا تردّد، وبدوافع إسلامية خالصة

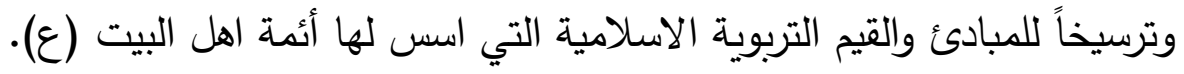


وحين ذكر جابر بن يزيد الجعفي رأي أخيه الباقر (ع) بثورته وسلامة قراره وذكر له أنّه مقتول لا محالة . قال زيد لجابر : قدابن

يا جابر لم يَسَعن أن أسكت، وقد خولف كتاب الله وتحوكم بالجبت والطاغوت، وذلك أنّي شاهدت هشاماً

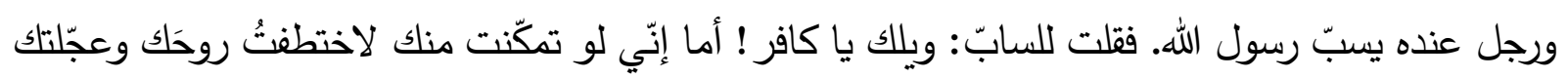

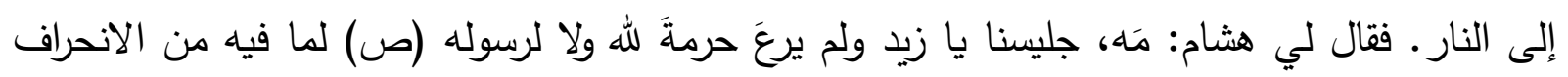
السلوكي.

قال زيد لجابر : فو الله لو لم يكن إلآَّأنا ويحيى ابني لخرجت عليه وجاهدته حتَّى أفنى (Yl) . لقد فَجَّر زيد ثورته وحقَّق نصراً حاسماً ضد الأمويين بعد أن خاض حرباً طاحنة كادت أن تنتهي لصالح زيد لولا وقوع الفتتة في صفوف أتباعه حيث احتال عليه بعض فَن كان يهوى هشاماً فذخلوا عليه وقالوا: ما تقول في أبي بكر وعمر؟ فقال زيد: رحم الله أبا بكر وعمر صاحبي رسول الله (ص) ثم قال: أين كنتم قبل اليوج؟ لقد كان الغرض من إلقاء السؤال في ذلك الموقف الحرج وفي ساحة الحرب هو أحد أمرين وفي

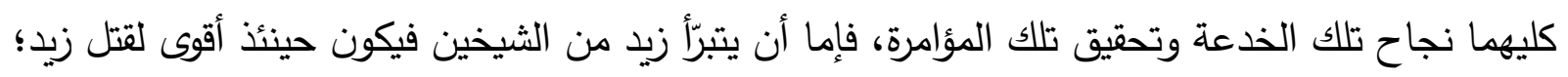

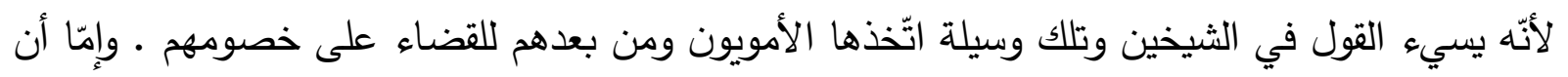
لا يتبرأ ممّن ظلم أهل البيت حقّه فيكون جوابه على أيّ حال سبباً لإيجاد الخلاف بين أصحابه وبالفعل نجحت المؤامرة وتفرّق أهل الغدر وذوو الأطماع وكانت هذه الحيلة من الوالي يوسف بن عمل عمر أقوى سلاح

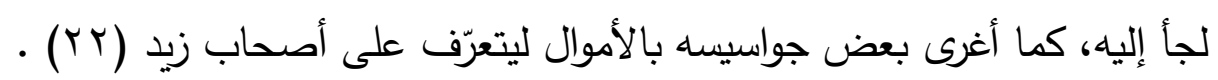

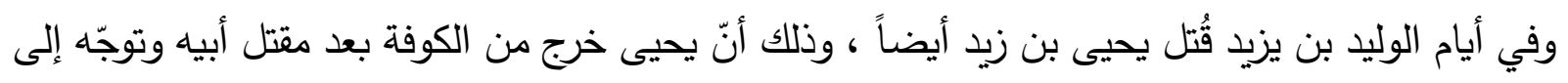

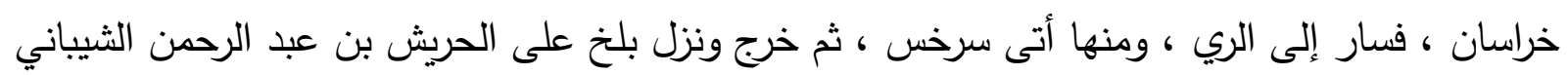
ولم يزل عنده حتّى هلك هشام وولي الوليد. 
وكتب والي الكوفة إلى نصر بن سيار يخبره بأنّ يحيى بن زيد موجود في منزل الحريش، وهنا طلب نصر

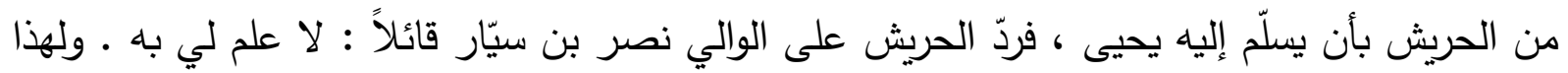
السبب ضُرب الحريش ستمائة سوط ـ ثم قال الحريش: والله لو أنّه تحتَ قدميّ ما رفعتهما. وبقيت أجهزة النظام تراقبه، وجرت بعد ذلك حوادث يطول ذكرها، وأخيراً أرسل نصر جيشاً يُعِّر بعشرة آلاف

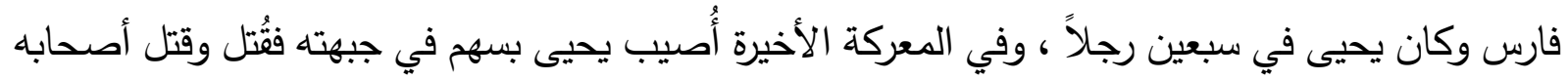

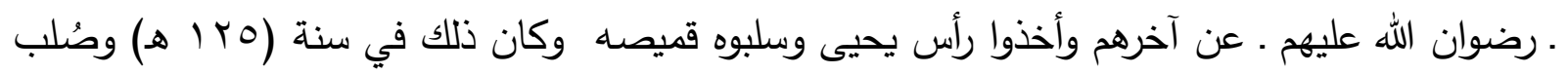

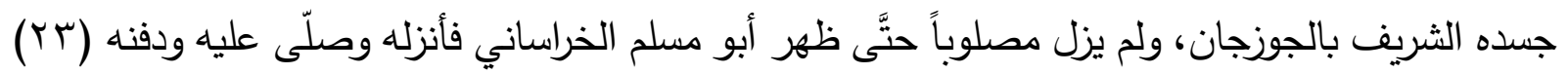

وفي سنة ( ب rا هـ ) قُتل الوليد بن يزيد من قِبل الأمويين أنفسه وتوّلى الخلافة من بعده يزيد بن الوليد

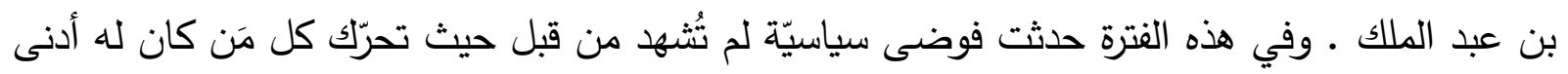
طمع في الرئاسة ؛ لأنّ الأمّة في هذا الظرف كانت مستعدة لأن تستجيب لأيّّ لافتة تدّعي العدالة ، وتريد الانتقام من الأمويين ، فكانت تتقبل هذه الدعوات بلا فحص ولا تدقيق ؛ ولهذا ظهرت في هذا الظرف لهاب مذاهب سياسية شتّى وهذا الواقع السياسي لم يمكن مسكه ولا السيطرة عليه وتكريسه باتِّاه واحد من قِبل

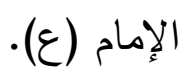
من هنا نجد أنّ موقفه (ع) من هذا الوضع كان موقف المصلح المرشد حيث نراه تارة يحذّر من الاندفاع

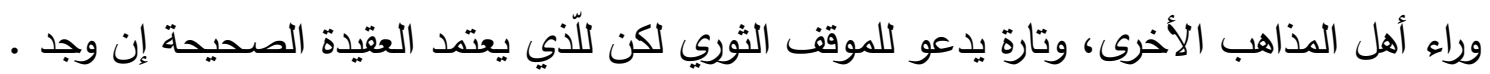

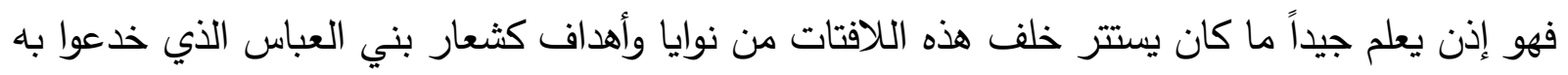

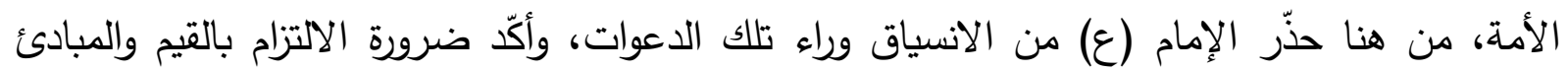
المفقودة، وأعطى ملامح الخط السياسي الذي كان ينسجم مع المرحلة، لكن ليس على حساب الإمان العمل الجهادي الذي يستهدف الأمويين ، وهذا ما شاهدناه من خلال مواقفه (ع) من ثورة زيد ودعمه لها. 
ثانيا : الوضع الفكري:

إنّ الظواهر الفكرية والعقائدية السائدة في عصر الإمام الصادق (ع). مثل: الزندقة، الغلّو، والاعتزال، والجبر

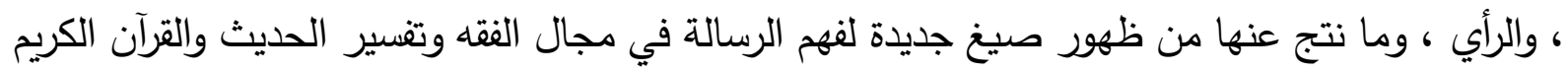

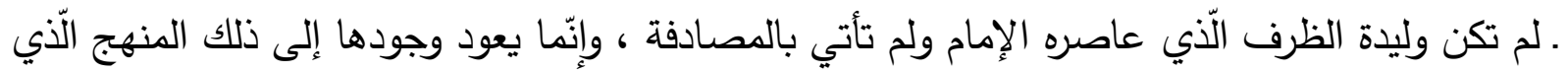

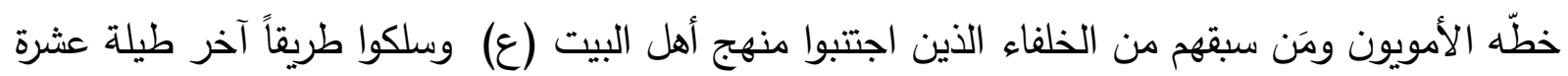

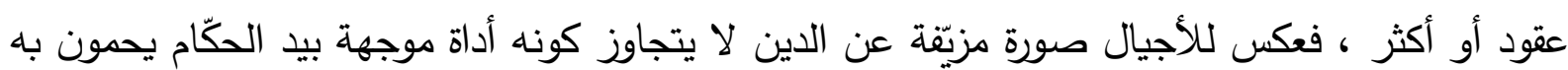

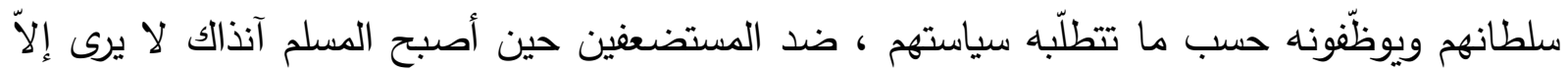
الصورة المقيتة عن الدين ؛ ولهذا كانت الزندقة ردّة فعل لهذا الانحراف بعد تلاعب الحكّام بالدين ، وقد فئد لقيت رواجاً في هذا الوسط الديني المضطرب والمليء بالمفاهيم الخاطئة.

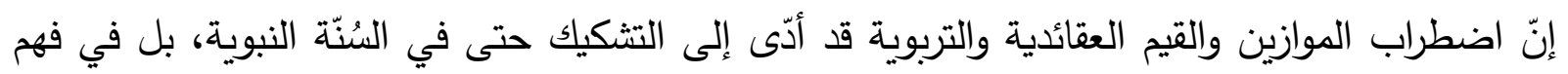

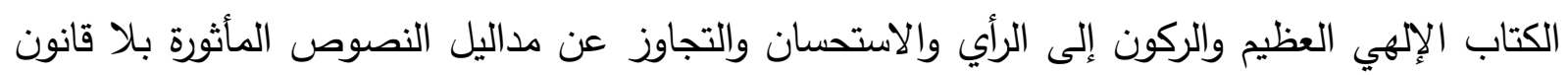
• علمي قويم إذإن فإذا أردنا أن نحاكم الأفكار المنحرفة ومنها التربوية التي انتشرت في عصر الإمام الصادق (ع) كان علينا

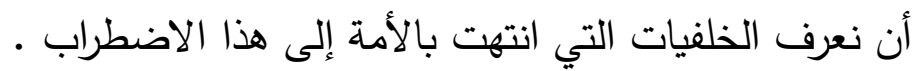

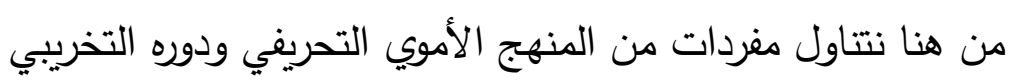
في فهم القرآن والسنّة وحوادث التاريخ ، مقتصرين على ذكر التهر بعض التحريفي ودور النماذج في كل مجال . ثالثا : تحريف مصادر التشريع والتاريخ : أ ـ التحريف في مجال تقسير القرآن الكريم كان التعامل مع النص القرآني وتفسيره يعتمد الرأي أو الروايات الإسرائيلية ، ويوظّّف لصالح سياسة الخليفة

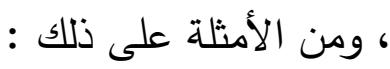


1 ـ استخدم المجبّرة النصوص القرآنية لتأييد نظريتهم مثل قوله تعالى: (والله خلقكم وما تعملون) ، زاعمين

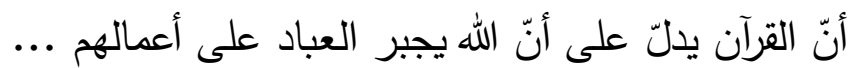

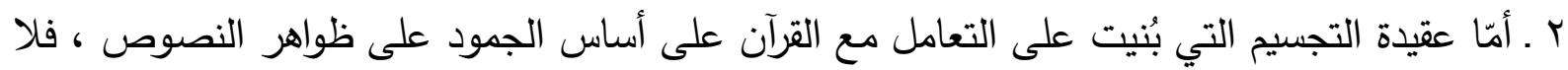
تتجاوز المعنى الحرفي للفظ حتى أخذت تصرّح بأنّ لله يداً ووجهاً محتجّة بقوله تعالى: (يد الله فوق أيديهم

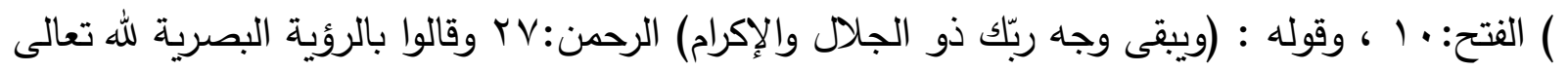

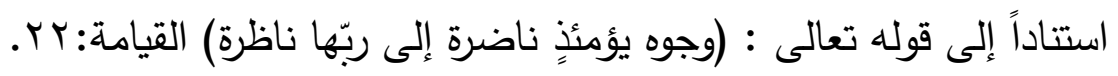

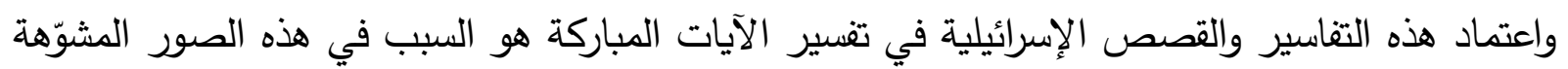

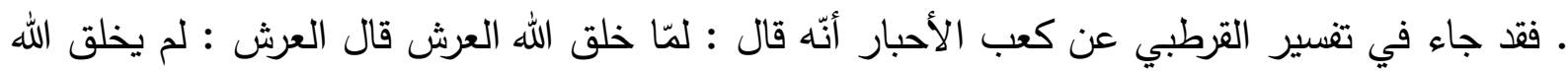

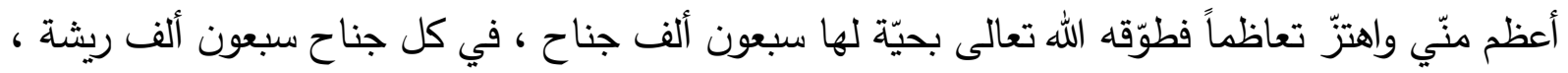

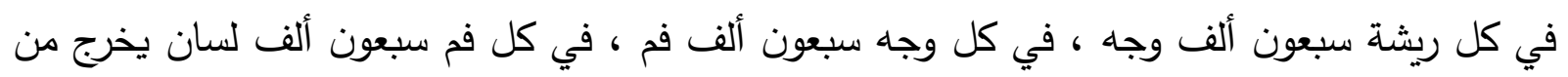
أفواهها كل يوم من التسبيح عدد قطر المطر ، لا عدد ورق الثجر ، وعدد الحصى والثرى ، وعدد أيام الدنيا وعدد الملائكة أجمعين ، والتوت الحيّة على العرش ، فالعرش إلى نصف الحيّة وهي ملتوية عليه

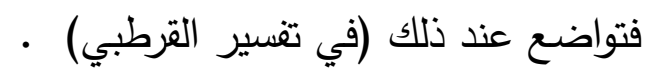
وقال معاوية لكعب أنت تقول: إنّ ذا القرنين كان يربط خيله بالثريّا؟ فقال له كعب: إن كنت قلت ذلك فإنّ

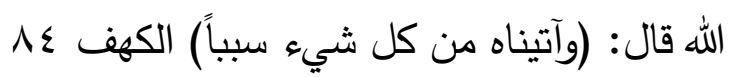

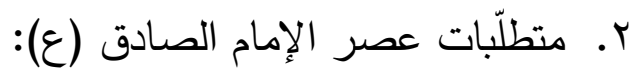
بعد الوقوف على مظاهر الفساد والاتحراف التي عمّت ميادين الحياة في عصر الإمام الصادق (ع) نستطيع

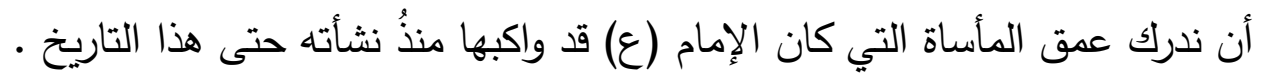
وفي هذا الظرف الذي خفّت فيه المراقبة بسبب ضعف الدّام الدولة الأموية، ووجد الإمام (ع) أنّ جانباً كبيراً من

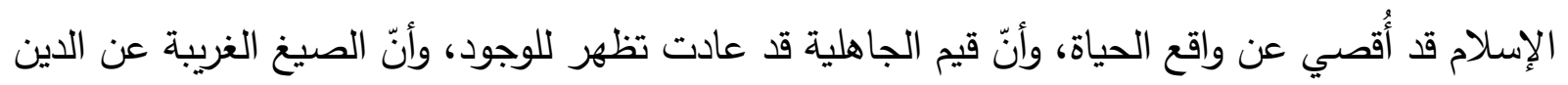


أخذت تدخل في فهم القرآن والسنّة الثريفة وتسبّبت في تغيير مضمون الرسالة وجوهرها، لاحظ أنّ الأمر

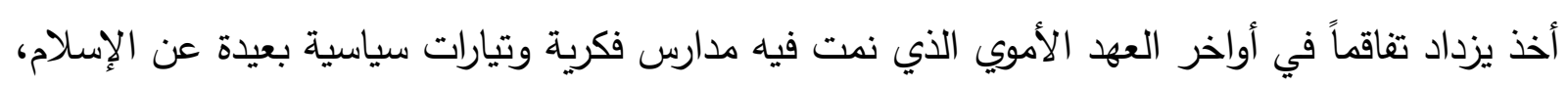

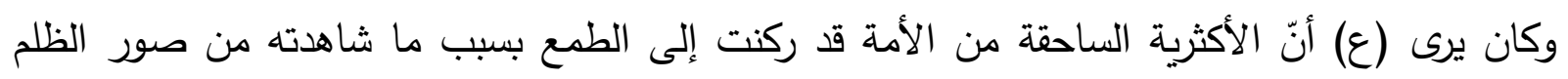

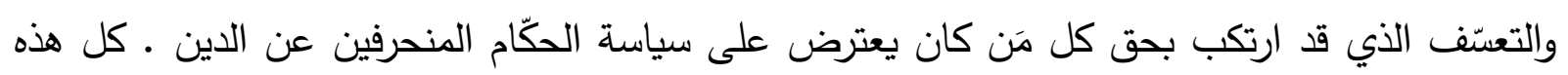

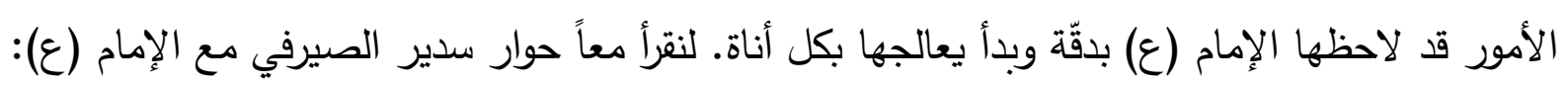

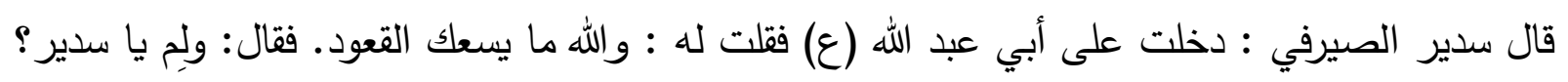

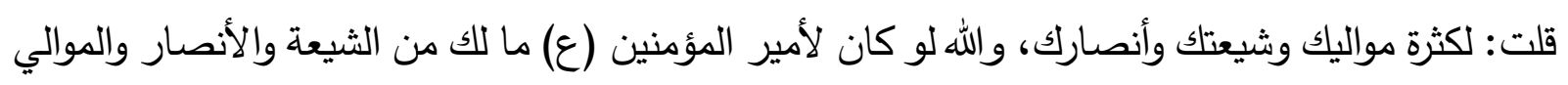
ما طمع فيه تيم ولا عديّ.

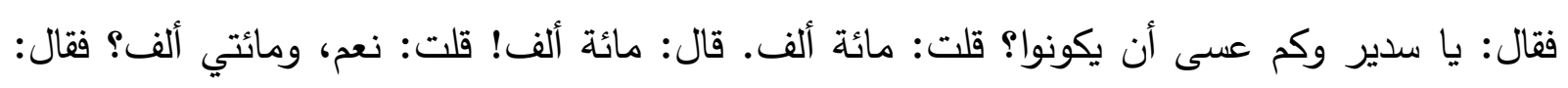

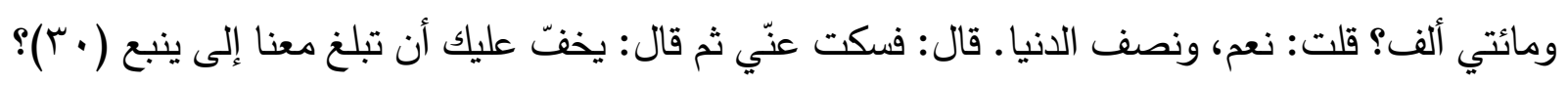

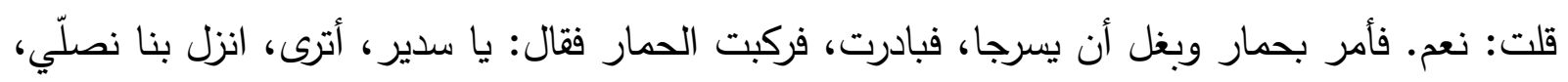

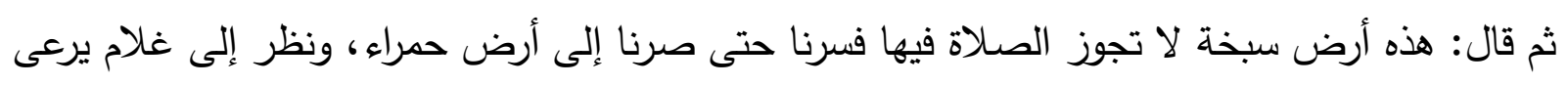

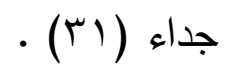
فقال والله يا سدير لو كان لي شيعة بعدد هذه الجداء ما وسعني القعود. ونزلنا وصلّينا فلمّا فرغنا من الصلاة

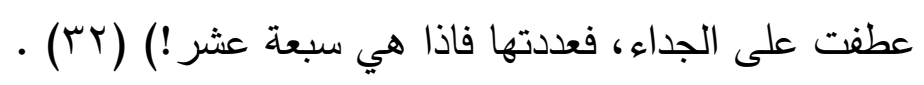

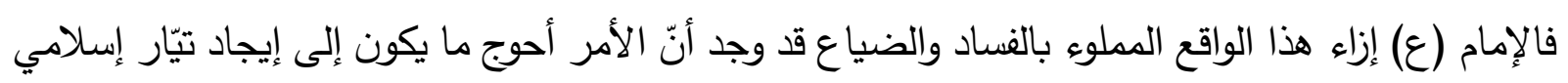

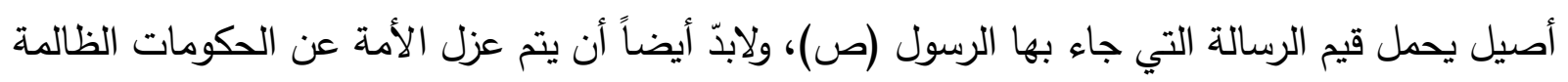

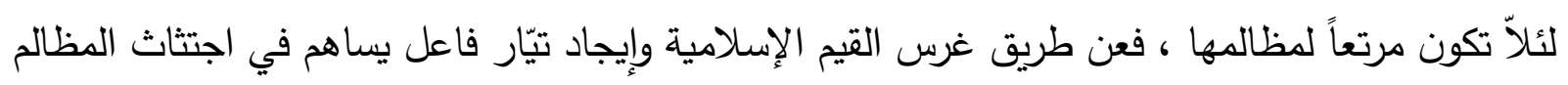

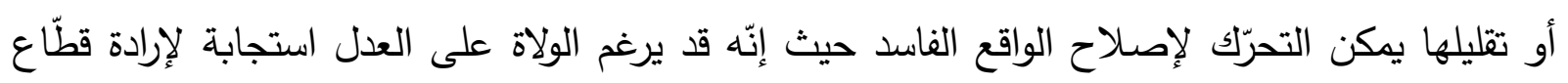

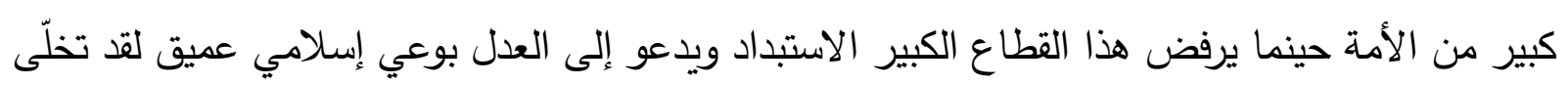


الإمام الصادق (ع) عن ممارسة العمل المسلح ضد الحكّام المنحرفين بشكل مباشر ، وكان موقفه هذا تعبيراً

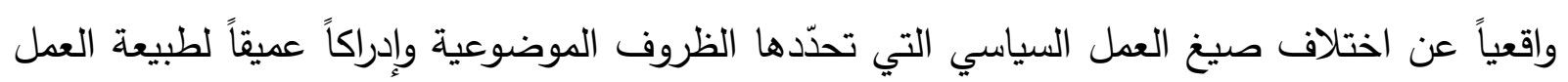
التغييري فالإمام (ع) حاول أن ينشر قيمه ومفاهيمه الدعوية بعيداً عن التصريحات السياسية الثورية، واتِجه نحو

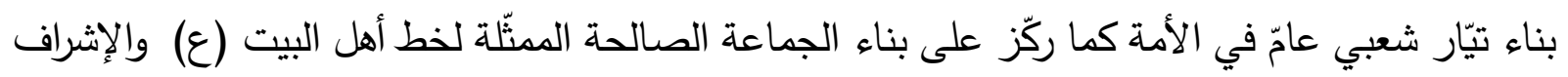
عليها وتنظيم أساليب عملها في مواجهة الانحراف المستشري بحيث يجعلها كتلة مترابطة في العمل والتغيير

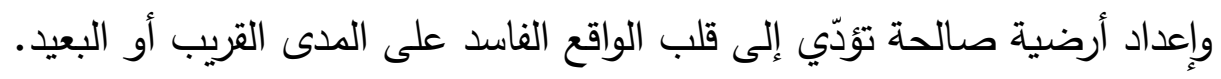
وقد استهدف الإمام (ع) في نشاطه الرسالي لونين من الانحراف :

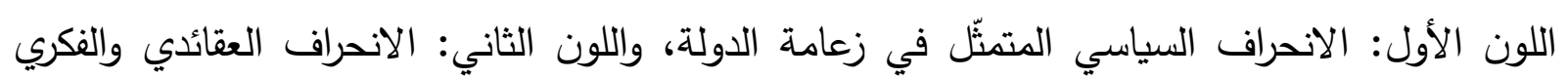

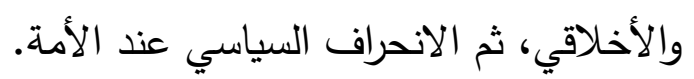

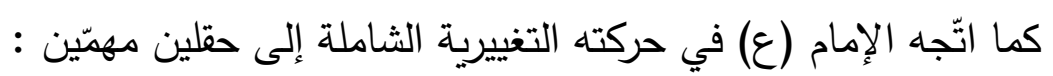

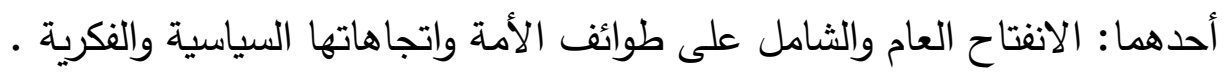

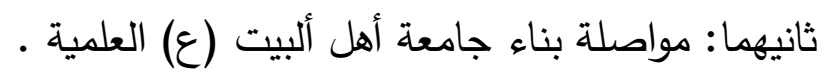

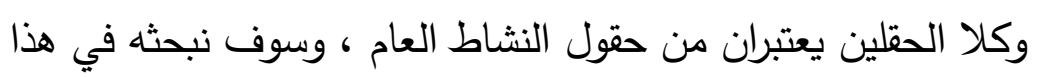

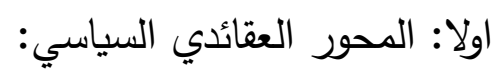
وفي هذا المحور ركّز الإمام على عدّة نشاطات:

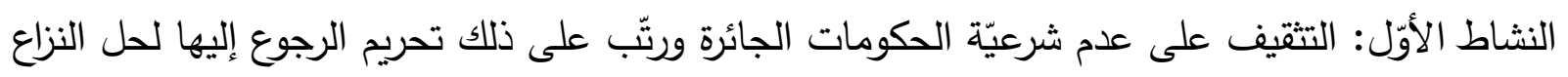
والخصومات كما ورد عنه: (إيّاكم أن يحاكم بعضكم بعضاً إلى أهل الجوريه ولكن ولثن انظروا إلى رجل منكم

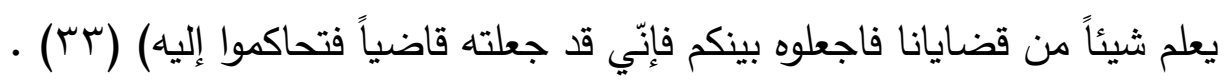


وقال أيضاً: (أيّما مؤمن قدّم مؤمناً في خصومة إلى قاضٍ أو سلطان جائر فقضى عليه بغير حكم الله فقد

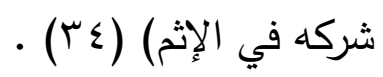
وعن أبي بصير عنه (ع) قال: (أيّما رجل كان بينه وبين أخ له ممارات في حق فدعاه إلى رجل من إخوانه

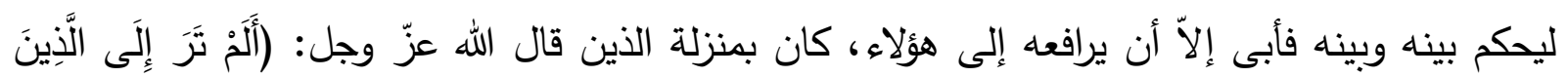

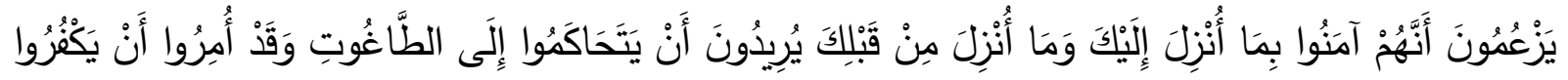

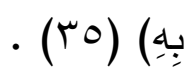
وعن عمر بن حنظلة قال: سألت أبا عبد الله عن رجلين من أصحابنا بينهما منازعة في دين أو ميراث

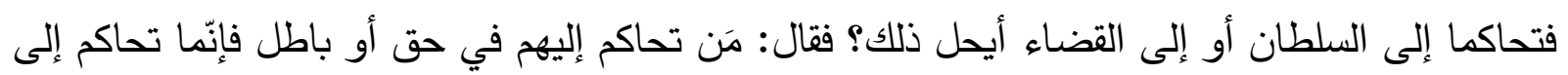

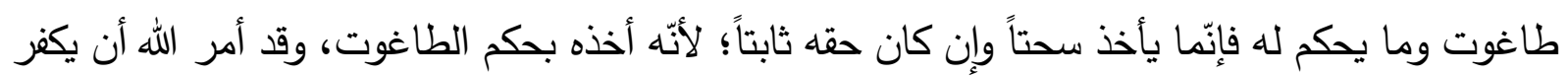

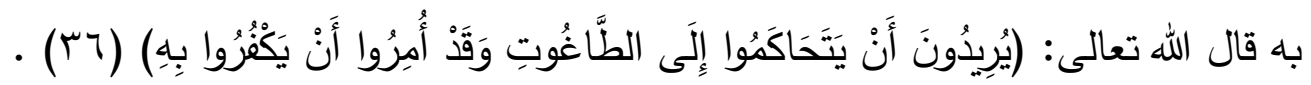

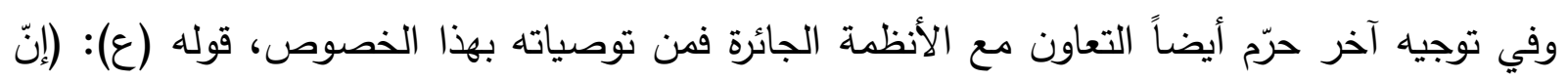

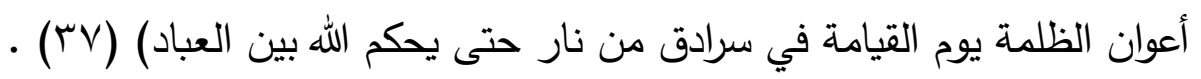

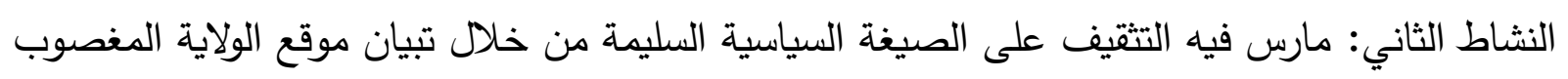
واستخدم الخطاب القرآني في هذا المجال الذي حاولت فيه المدارس الفكرية الأخرى تجميد النص بحدود

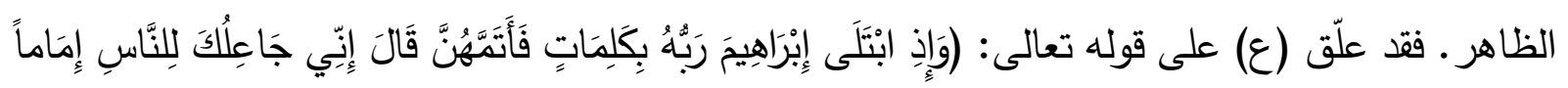

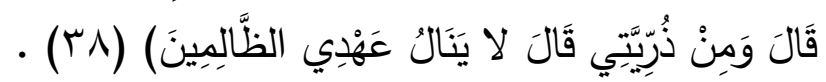

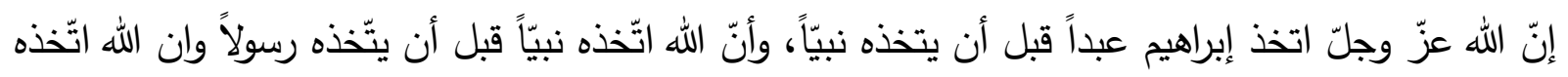

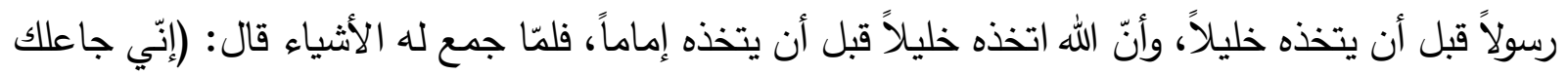
•لناس إماماً) 
قال (ع): (فَمن عِظَكِها ـ أي الإمامة . في عين إبراهيم (ع) قال: ومن ذرّيتي؟ قال: لا ينال عهدي الظالمين، قال: لا يكون السفيه إمام التقي). كما فمّر (ع) قوله تعالى: (صبغة الله ومَن أحسن من الله صبغة ونحن له عابدون) (9 ب) بأنّ الصبغة هي

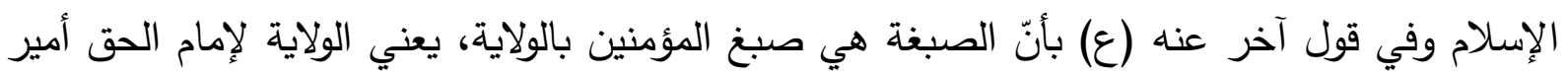
المؤمنين (ع) في الميثاق. كما نجده (ع) يتحدث عن الإمام أمير المؤمنين ويذكّر الناس بحديث الغدير ، ذلك الحدث السياسي الخطير في حياه الأمة، ويذكّرهم به لئلاّ يتعرّض هذا الحدث للنسيان والإلغاء. قال في حق علي (ع) (المدعو له له بالولاية المثبت له الإمامة يوم غدير خم، بقول الرسول (ص): ألست أولى بكم من أنفسكم؟ قالوا: بلى قال:

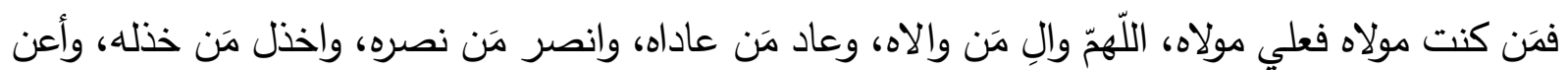
مَن أعانها)

وعندما التقى وفد من المعتزلة في مستوى رفيع ضمّ أعلامهم ورؤوسهم فكان من بينهم : عمرو بن عبيد وواصل بن عطاء وحفص بن سالم، وذلك بعد قتل الوليد واختلاف أهل الثام ، وقد أجمع رأي المعتزلة

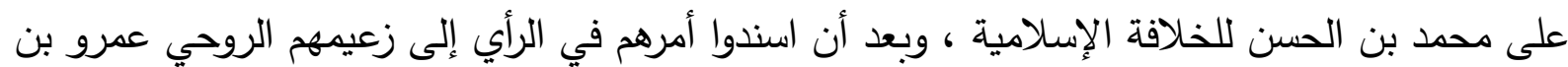

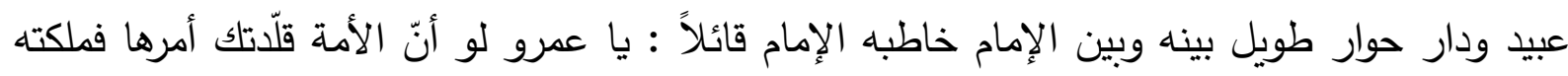

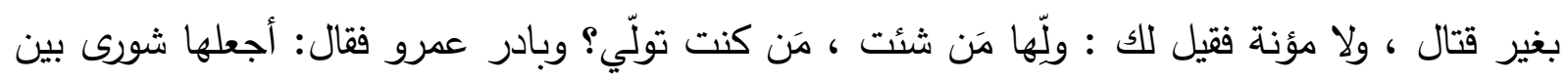
المسلمين.

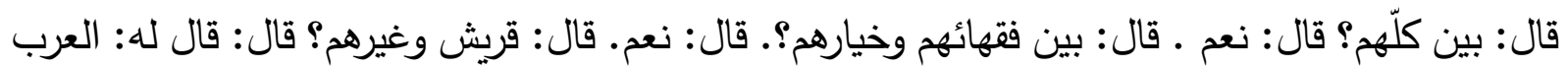

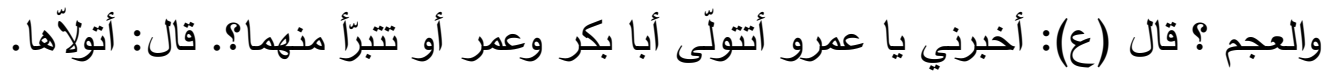

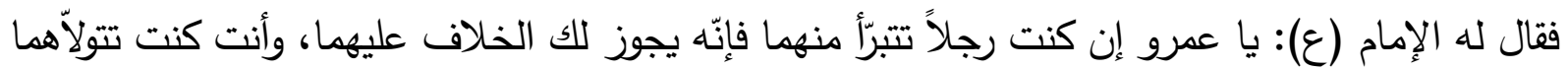
فقد خالفتهما. فقد عهد عمر إلى أبي بكر فبايعه، ولم يشاور أحداً، ثم ردّها أبو بكر عليه ولم يشاور أحداً، لئال 
ثم جعلها عمر شورى بين ستة، فأخرج منها الأنصار غير أولئك الستة من قريش، ثم أوصى الناس فيهم .

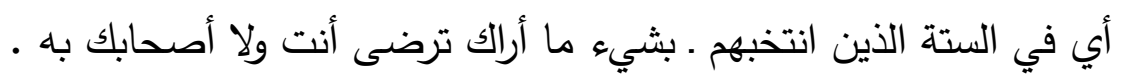

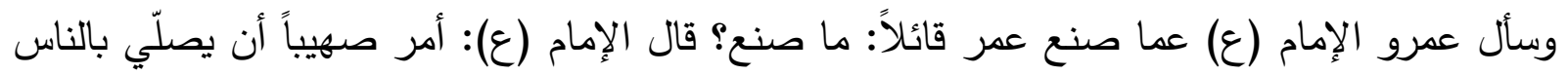

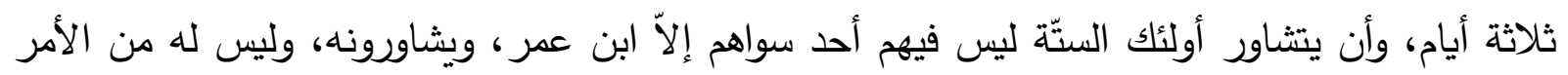

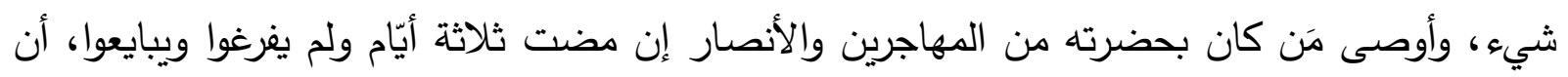

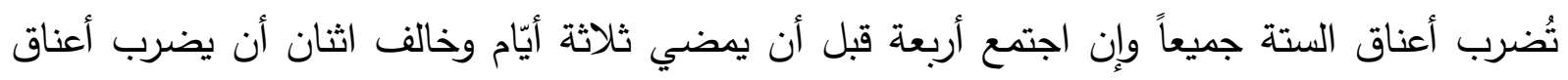

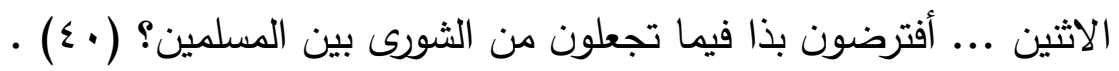

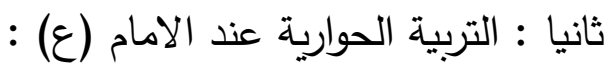

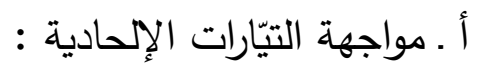

ومن الخطوات التي خطاها الإمام (ع) هي مواجهة الأفكار الإلحادية ـ سابقة الذكر . حيث ناقشها بعدّة أساليب حتى استقرغ محتواها ووقف أمام تحقيقها لأهدافها

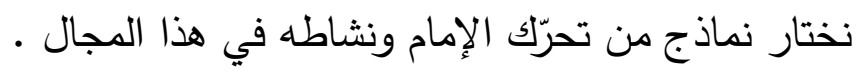
1 ـ جرت بين الإمام وأحد أقطاب حركة الكفر والإلحاد (أبو شاكر الديصاني) عدّة مناظرات أفحمه الإمام فيها، وأبطل مزاعمه الواهية، وكان من بينها المناظرة التي وجّه فيها أبو شاكر السؤال التالي للإمام (ع):

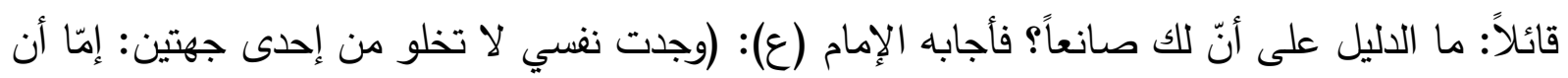
أكون صنعتها أنا أو صنعها غيري. فإن كنت صنعتها فلا أخلو من أحد معنيين: إمّا أن أكون صنعتها إنها وكانت موجودة فقد استغنيت بوجودها عن صنعتها، وإن كانت معدومة فإنّاك تعلم أنّ المعدوم لا يحدث إنّا

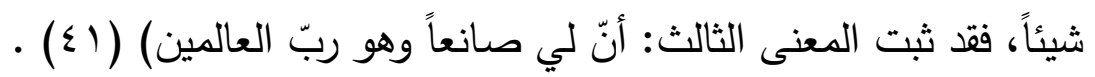

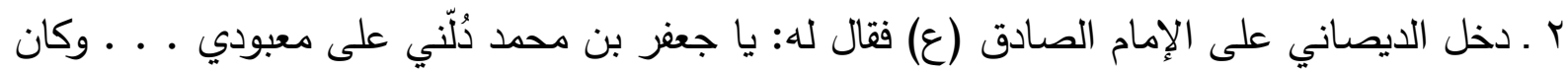

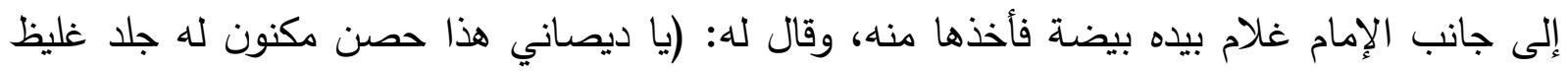


وتحت الجلد الغليظ جلد رقيق، وتحت الجلد الرقيق ذهبة مائعة وفضة ذائبة فلا الذهبة المائعة تختلط بالفضة الذائبة ولا الفضة الذائبة تختلط بالذهبة المائعة، فهي على حالها لم يخرج منها خارج مصلح فيخبر

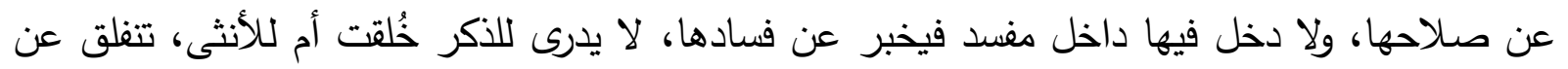

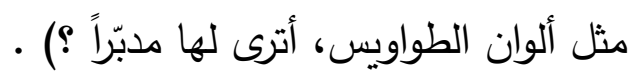

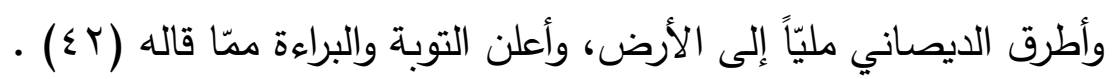
r ـ ووفد زنديق آخر على الإمام (ع) وهو من الزنادقة البارزين في عصر الإمام الصادق الإقلى (ع) وقد قدّم

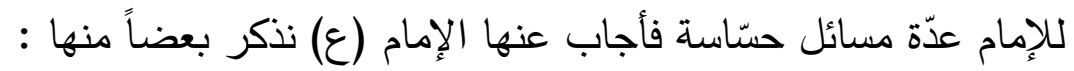

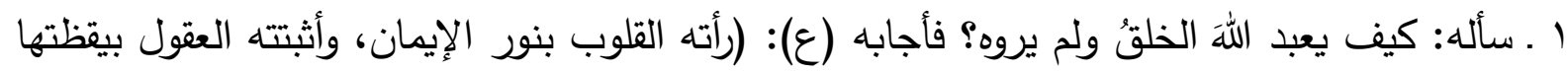

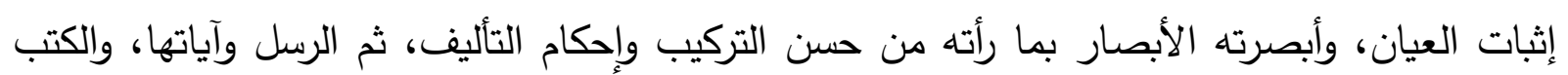

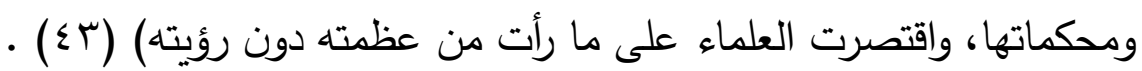
ويتضمّن جواب الإمام (ع) بعض الأدلة الوجدانية على وجود الخالق من خلقه للدجرّات في الفضاء والتي لا تعتمد على شيء سوى قدرة الله تعالى .

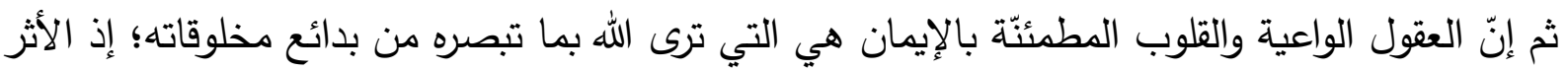

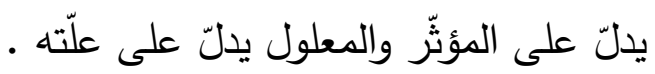

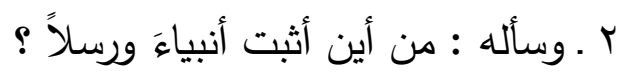

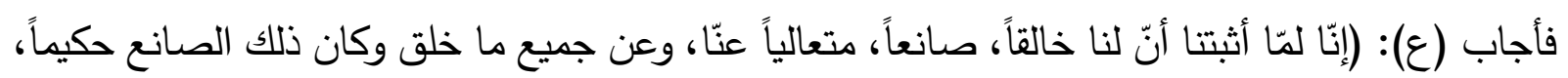
لم يجز أن يشاهده خلقه، ولا أن يلامسوه ولا أن يباشرهم ويباشروه، ويحاجّهم ويحاجّوه، ثبت أنّ له سفراء

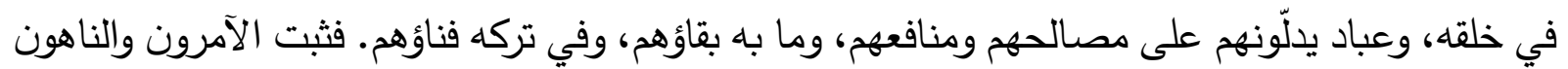

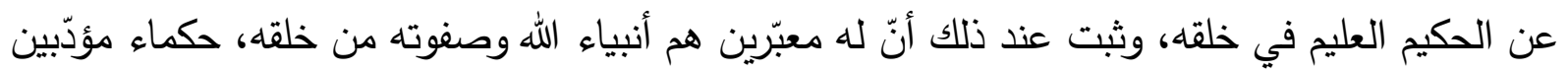
بالحكمة مبعوثين عنه، مشاركين للناس في أحوالهج على مشاركتهم لهم في الخلق والتركيب، مؤيّدين من 
عند الحكيم العليم بالحكمة والدلائل والبراهين والثواهد من إحياء الموتى وإبراء الأكمه والأبرص، فلا تخلو الأرض من حجّة يكون معه علمُ يدلّ على صدق مقال الرسول ووجود عدالته.

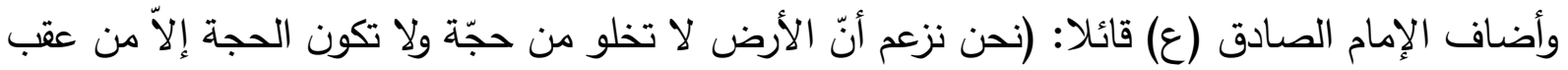

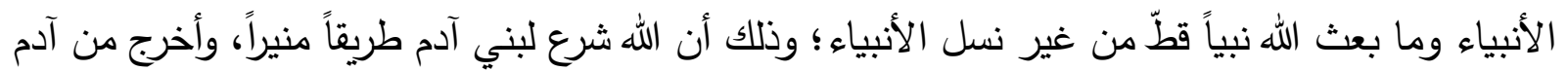

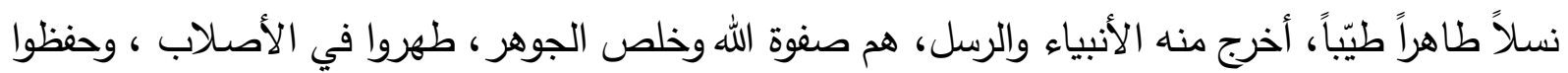

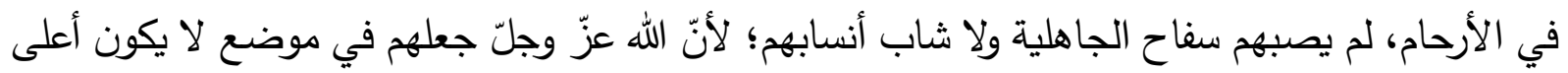

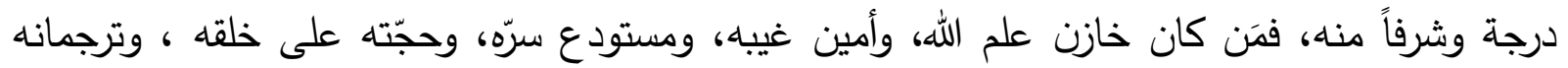

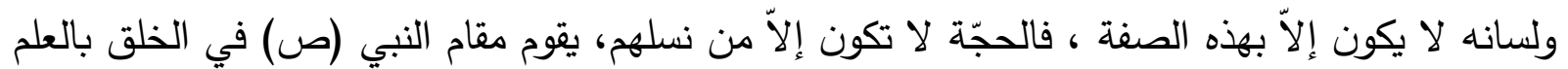

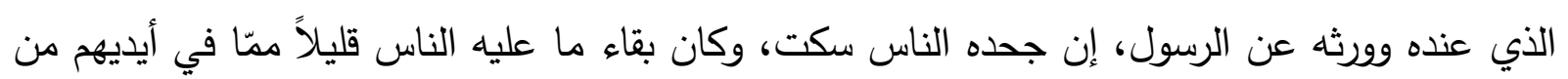
علم الرسول على اختلاف منهم فيه، قد أقاموا بينهم الرأي والقياس، وإنّهم إن أقرّوا به وأطاعوه وأخذوا عنه الهاء ظهر العدل، وذهب الاختلاف والتشاجر ، واستوى الأمر ، وأبان الدين ، وغلب على الثك اليقين ، ولا يكاد

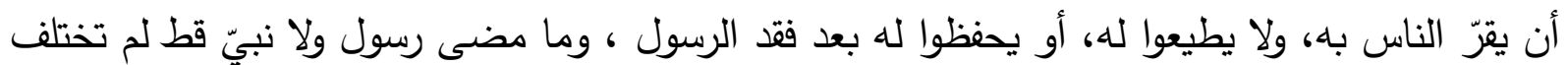

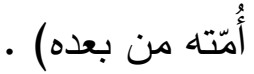

وبهذا المستوى من الحوار وعمقه يستمرّ الإمام (ع) في أجوبته العملاقة حتى تصل الأسئلة والأجوبة إلى

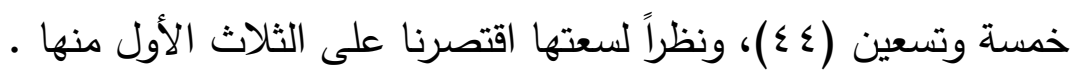

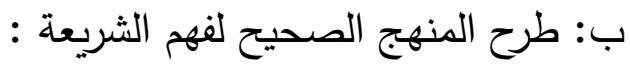
إنّ الإمام الصادق (ع) في الوقت الذي كان يواجه هذه التيارات الإلحادية الخطيرة على الأمة كان مشغولاً أيضاً بمواجهة التيّارات التي تتبنّى المناهج الفقهية التي تتتافى مع روح التشريع الإسلامي، والتي تكمن

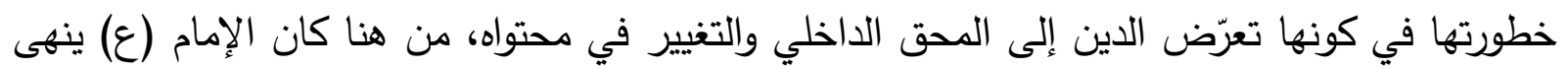

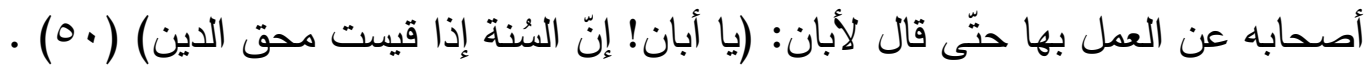


وكان للإمام نشاط واسع لإثبات بطلان هذه المناهج وبيان عدم شرعيّها .

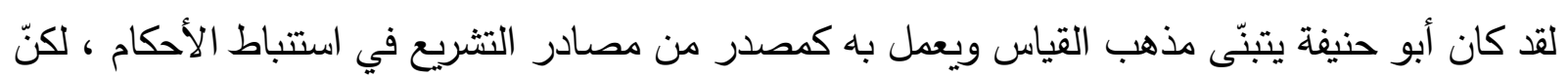

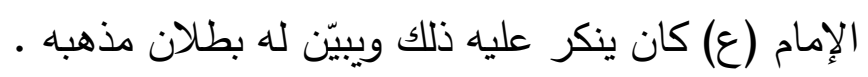
وإليك بعض المحاورات التي جرت بينه وبين الإمام (ع): ذكروا أنّه وفد ابن شبرمة مع أبي حنيفة على الإمام الصادق (ع) فقال لابن شبرمة : (مَن هذا الذي معك الإن

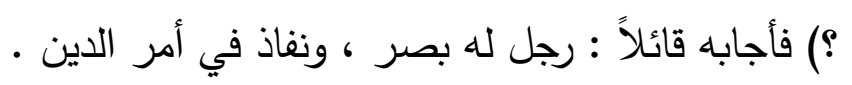

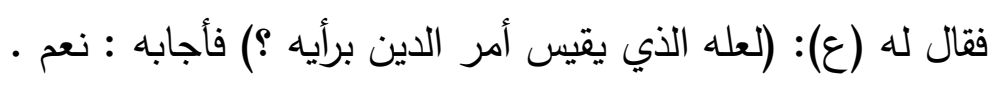

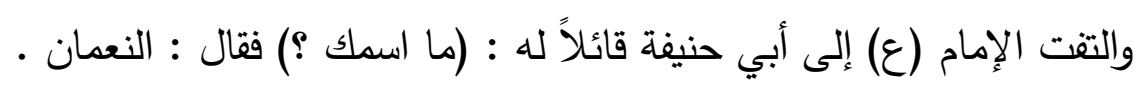

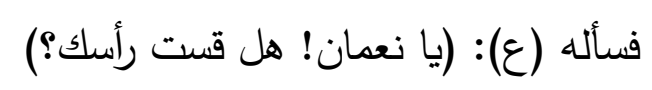

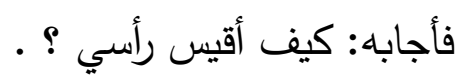
فقال له (ع): ما أراك تحسن شيئاً . هل علمت ما الملوحة في العينين؟ والمرارة في الأذنين، والبرودة في المنخرين والعذوبة في الثفتين؟ فبهر أبو حنيفة وأنكر معرفة ذلك ووجّه الإمام إليه السؤال التالي: (هل علمت كلمة أوّلها كفر، وآخرها

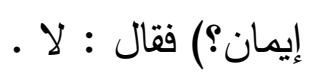
والتمس أبو حنيفة من الإمام أن يوضّح له هذه الأمور فقال له (ع): (أخبرني أبي عن جذّي رسول الله

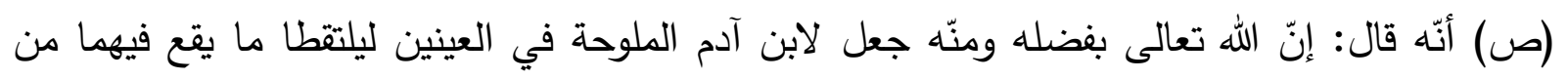

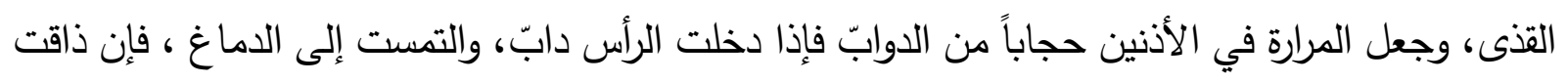

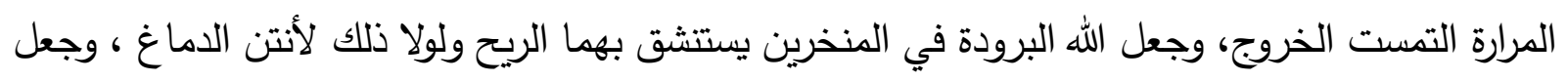
العذوبة في الشفتين ليجد لذة استطعام كل شيء) . والتثت أبو حنيفة إلى الإمام (ع) قائلاً: أخبرني عن الكلمة التي أوّلها كفر وآخرها إيمان؟ 
فقال له (ع): (إنّ العبد إذا قال: لا إله فقد كفر فإذا قال إلاّ الله فهو الإيمان) . وأقبل الإمام على أبي حنيفة ينهاه عن العمل بالقياس حيث قال له: (يا نعمان حدثني أبي عن جدّي رسول الله (ص) أنّه قال: أوّل مَن قاس أمر الدين برأيه إبليس ، قال له الله تعالى: اسجد لآدم فقال: (أنا خير منه لئه

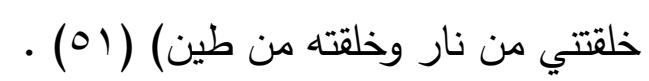
والتقى أبو حنيفة مرّة أخرى بالإمام الصادق (ع) فقال منال له الإمام: (ما تقول في محرم كسر رباعيّة ظبي؟).

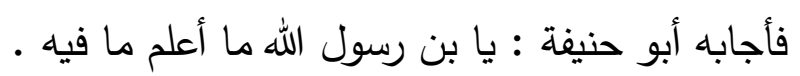

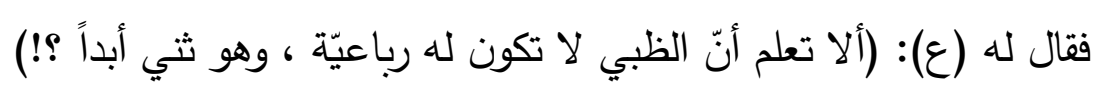

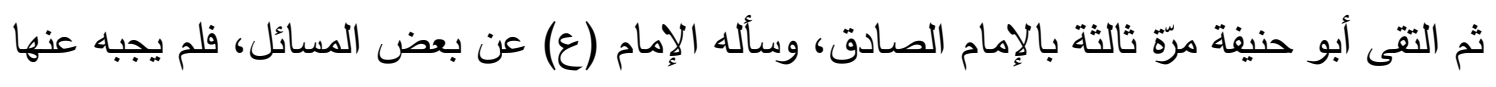

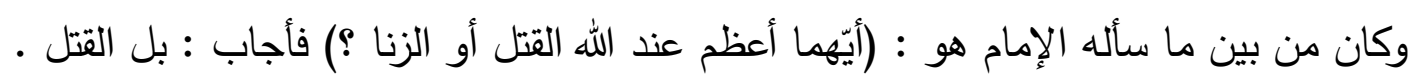
فقال (ع): (كيف رضي في القتل بشاهدين ، ولم يرضَ في الزنا إلاّ بأربعة؟) الزان

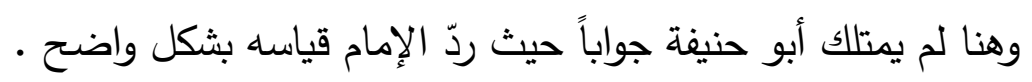

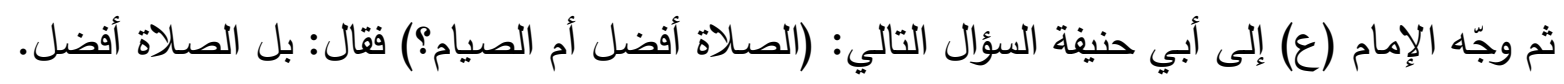
فقال الإمام (ع): (فيجب . على قياس قولك ـ على الحائض قضاء ما فاتها من الصلاة في حال حيضها

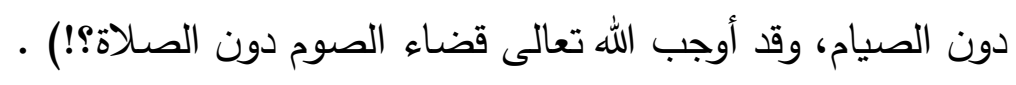
د: مواجهة التحريف والاستغلال السياسي للقرآن ومفاهيمه: قام الإمام الصادق (ع) بحماية القرآن وصيانته من عملية التوظيف السياسي، التي تجعل النص القرآني خادماً لأغراض سياسيّة مشبوهة ، تحاول إسباغ طابع شرعي على الحكم الظالم وشلّ روح الثورة وإطفاء

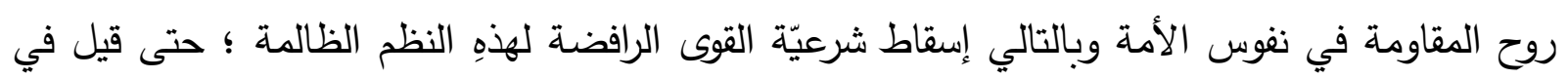

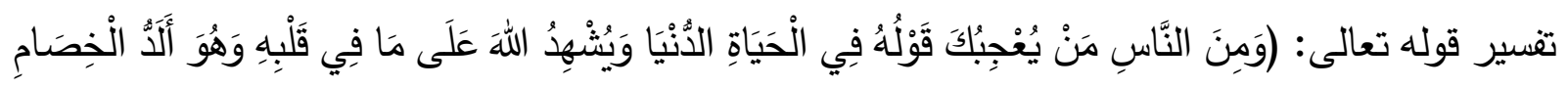

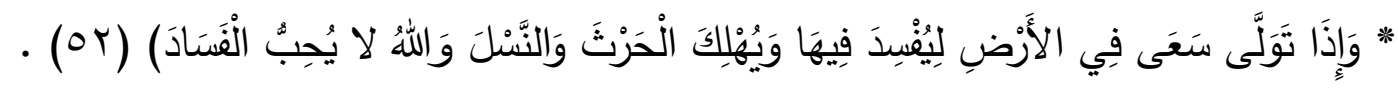




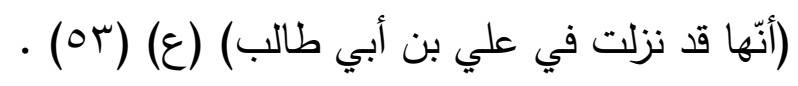

كما زيّف الإمام (ع) النظرة الجامدة للنصّ القرآني والتي تحاول تعطيله عن المواكبة للواقع المتغيّر والمتطوّر وحبسه في حدود الظاهر، ولم يسمح بالتأويل الباطني الفاسد. كما قاوم بعنف التفسير الذي يعتمد الرأي

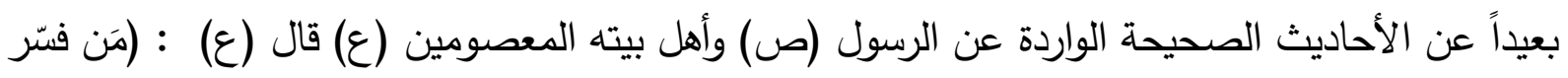

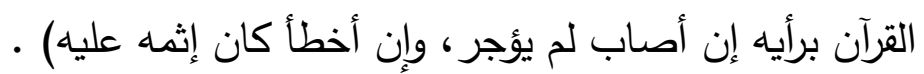

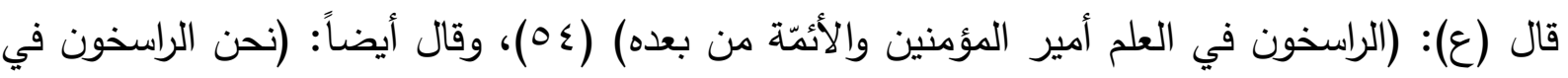

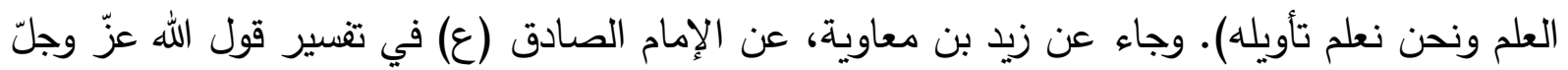

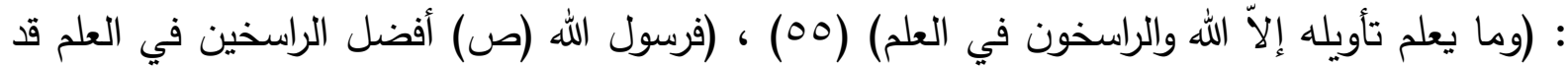

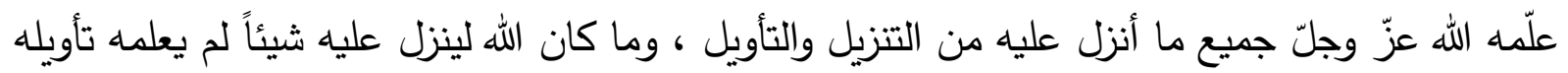

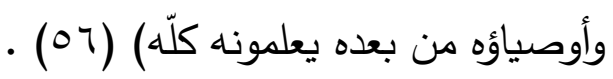
وجاء عنه (ع) في تفسير قوله تعالى: (بل هو آيات بيّنات في صدور الَّنين أوتوا العلم) أنّهم هم الأئمّة . ودخل عليه الحسن بن صالح بن حي فقال له: يا بن رسول الله! ما تقول في قوله تعالى الثي: (أطيعوا الله

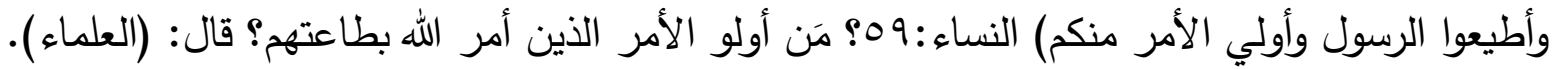

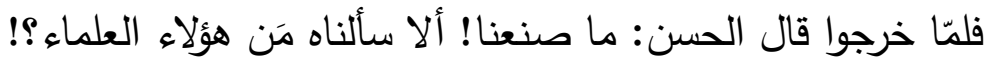

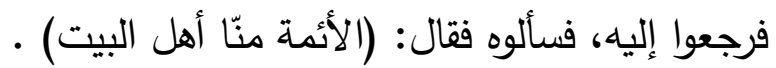
ثالثا : المحور الروحي والأخلاقي: لاحظ الإمام الصادق (ع) تأثير موجات الانحراف الفكري والسياسي على الأمة ومدى إفسادها لعقول الناس،

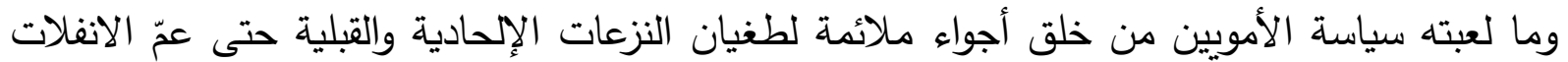

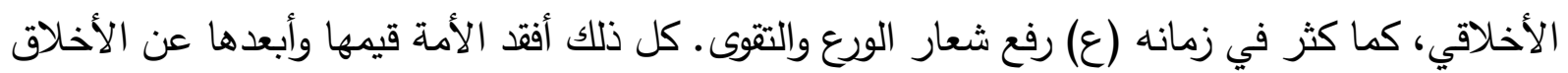
التي أمر بها الرسول (ص) وأرادها لأُّنته . 
من هنا كان دور الإمام (ع) وتوجّهه الروحي والأخلاقي مع الأمة في عدّة أبعاد :

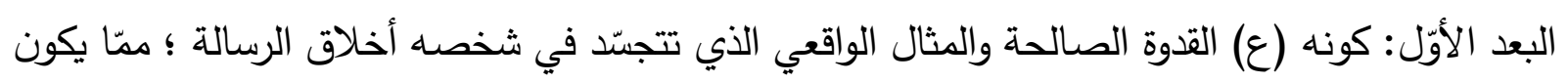

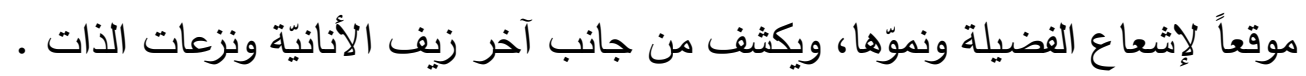

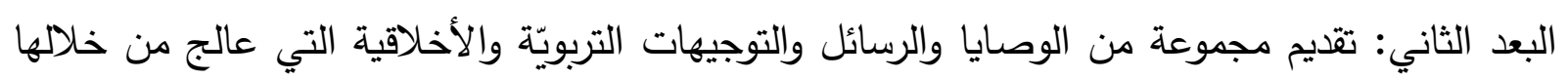

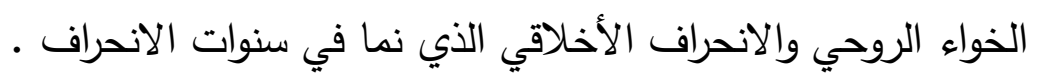
أمّا في البعد الأول فنجد الإمام (ع) كان يدعو الناس إلى الفضيلة برفق ولين ويجادلهم بالتي هي أحسن،

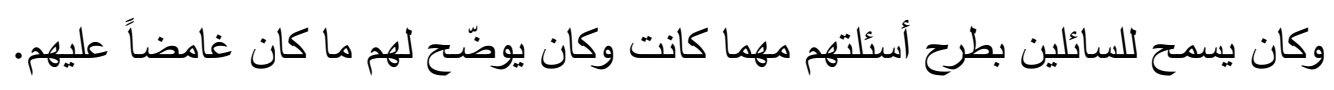
كما كان لا يقبل من مقرّبيه أن يتثدّدوا بدعوتهم حيث كان يقول لهم: (لأحملنّ ذنوب سفهائكم على علمائكم

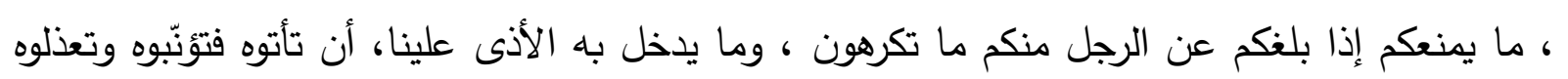

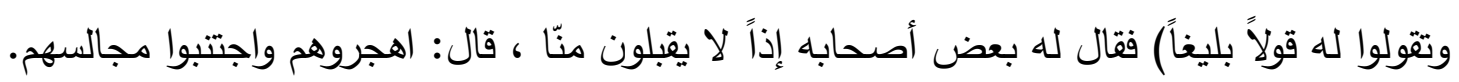

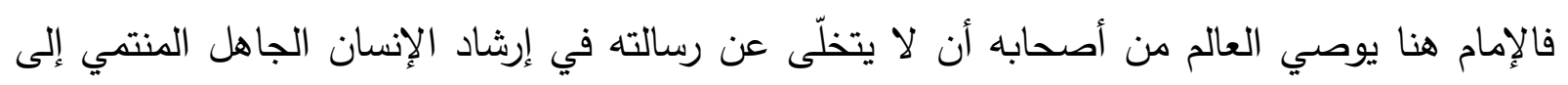

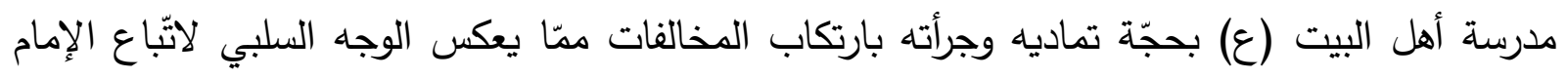

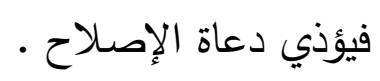

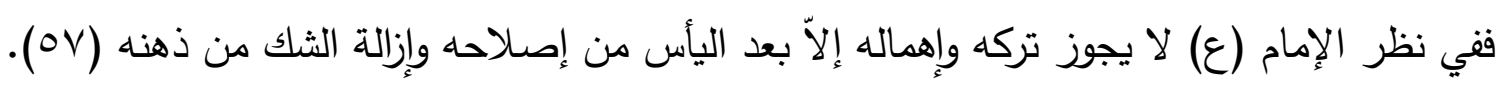

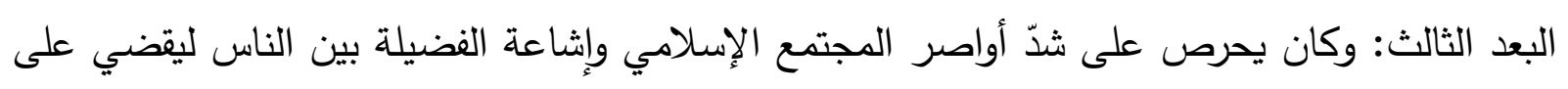

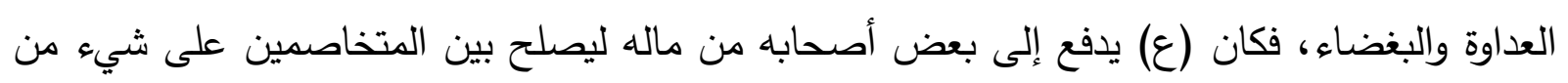

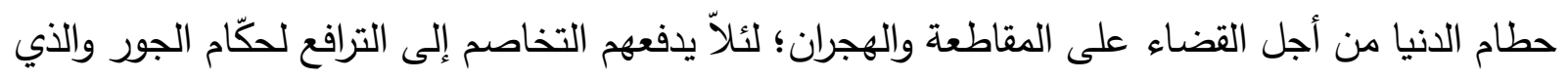

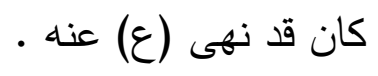
r. دور الإمام الصادق (ع) (عنه ف في بناء الجماعة الصالحة: 
لقد تحدّثنا عن طبيعة الظروف السياسية وتناقضاتها والمظاهر الحياتية المضطربة، والدور التخريبي الذي

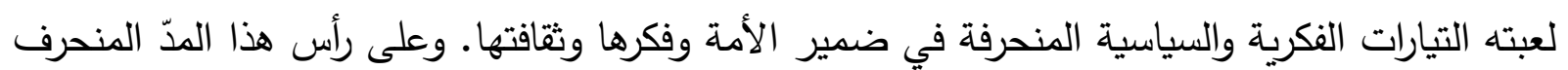

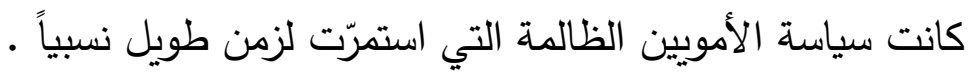

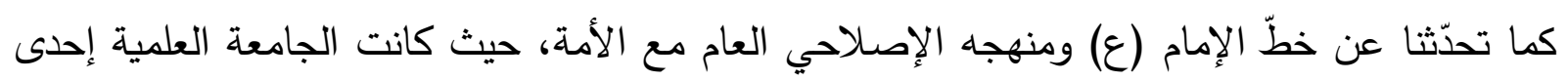
حلقات منهجه الإصلاحي الثامل . ولم يقتصر نشاط الإمام (ع) على بناء الجامعة العلمية وغيرها من الأنثطة العامة؛ لأنّّ كان يدرك جيداً

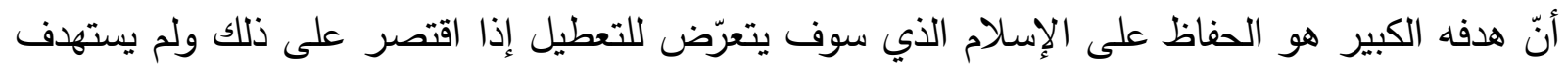

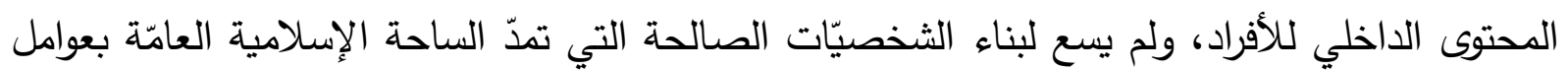
القوّة والبقاء والحفاظ على الأمة والدفاع عن مقدّساتها. اولا: الهدف من إيجاد الجماعة الصالحة:

من هنا كان تحرّك الإمام نحو بناء الجماعة الصالحة بهدف تغيير المجتمع الإسلامي وفق أطروحة أهل البيت (ع)؛ لأنّ وجود مثل هذا التيّار المتماسك يوفّر جملة من المكاسب والمنافع والأهداف التي كان يسعى الإنى الإمام (ع) لتحقيقها في حركته الرساليّة. إنّ الجماعة الصالحة تحقّق ديمومة خط أهل البيت (ع) حيث يشكّل وجودها خطوة عملية باتِّاه مشروعهم - الكبير ونلخّص فيما يلي بعض النقاط التي يُحققها وجود هذه الجماعة الصالحة.

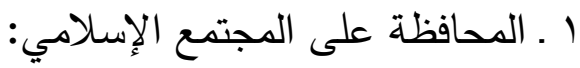
إنّ وجود هذا الخط في وسط الأمة سوف يوسّع من دائرة الأفراد الصالحين والواعين وكلّما اتّّعت هذه الإنها الدائرة كان الإمام (ع) أكثر اقتداراً على التغيير وإدارة العمل السياسي الذي يخوضه دالهـ مع الحكّام . 
ويمثّل هذا الخط القوّة التي تقف بوجه التحدّي الفكري والأخلاقي الذي واجهه العالم الإسلامي حينذاك، وقد

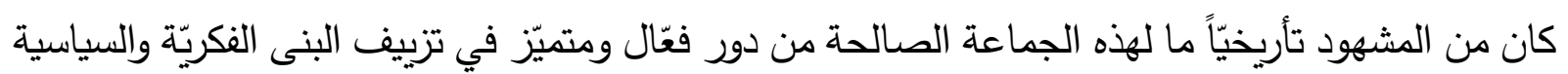
التي تعتمدها الفرق الضالّة من خلال مطارحاتهم ومناقثاتهم مع أقطاب تلك الفرق كالزنادقة والمجبّرة

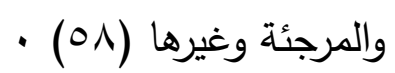
وامتاز أصحاب الإمام الصادق (ع) عن غيرهم بالمواقف الثجاعة والتميّك بالمثل والقيم العليا وعدم

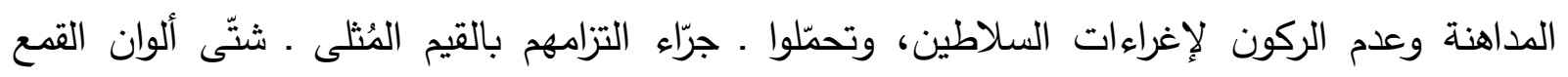

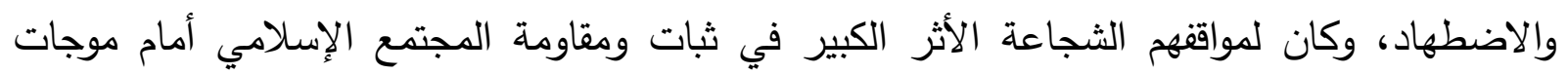
الانحراف.

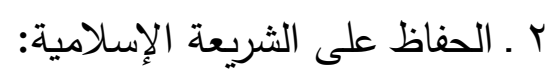

وقف الإمام الصادق (ع) ضدّ حملات التشويه التي أرادت أن تعصف بالثربعة الإسلامية وتعرّضها الإضيا للانحراف الذي أصاب الثرايع الأخرى من خلال دخول أفكار غريبة عن الثريعة بين أتباعها، واستخدام

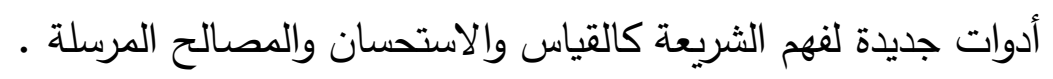
ونتيجة للمستوى العلمي الرفيع الذي كان يتمتّع به أصحاب الإمام وشيعته لم تصبح مسألة الإفتاء والاستتباط خاضعة لمصلحة السلاطين وأهوائه أو منسجمة مع متبنيّاتهم الفكرية، بل بقي الفهم الصحيح للكتاب والسُنّة

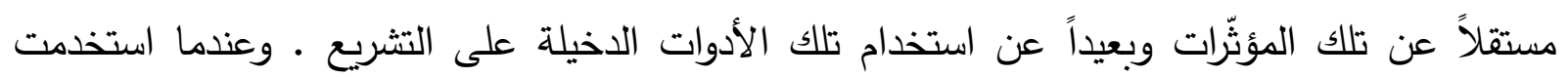

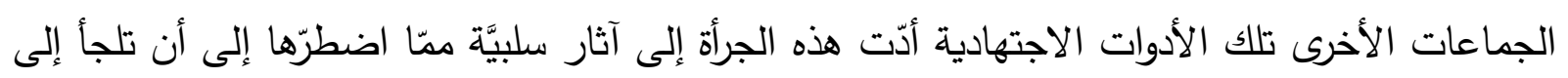

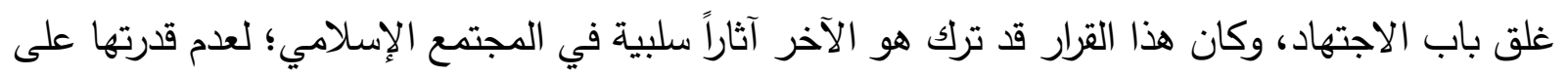

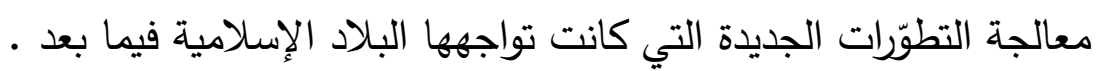


لقد أكّد الإمام الصادق (ع) قضية مهمّة واعتبرها رصيداً مهمّاً لفهم النصوص وتبيينها والاستنباط منها وتلك

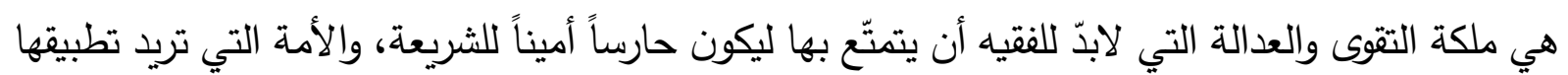
في الحياة.

والعدالة عند الإمام (ع) شرط في كثير من الممارسات الحياتية فهي شرط في إمام الجماعة وفي شهود

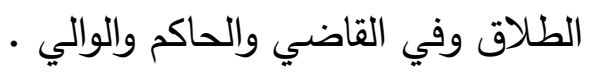
وهذه المزيّة لها دور كبير في حفظ الثريعة وحفظ النصوص الإسلامية بحيث تميز هذه المدرسة عن غيرها كما أنّ أصحاب الإمام (ع) لم يتعاملوا مع النصوص لهاب الواردة عن الرسول (ص) والأئمة (ع) كما تعاملوا

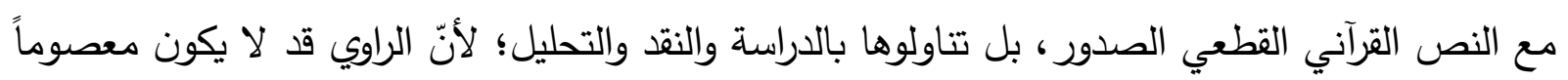
عندهم بالرغم من إيمانهم بعصمة الإمام المروي عنده.

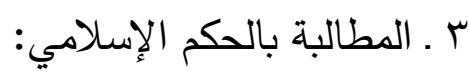
إنّ القيادة السياسية حق مشروع للأئمة المعصومين من أهل البيت (ع) وفق النصوص الإسلامية الثابتة عن الرسول (ص) والتي تواترت عند مدرسة أهل البيت (ع). ومن هنا كانت القيادة السياسية التي تولّت الحكم بعد الرسول (ص) مباشرة لا تحمل الصفة الشرعيّة بالرغم

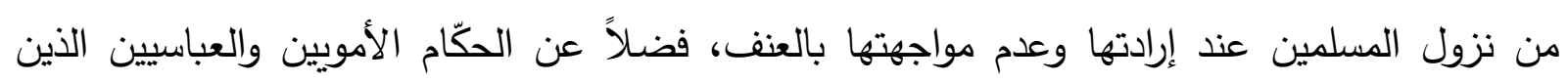

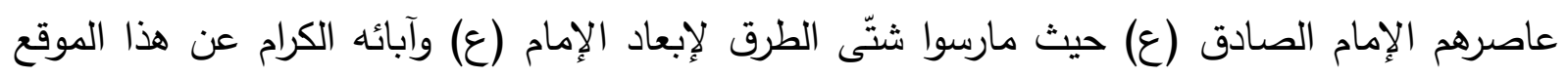

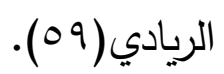

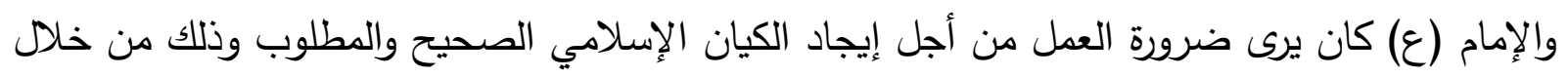

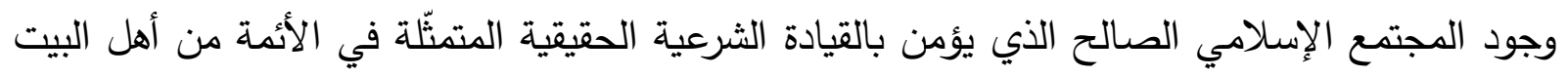


وهكذا كان الإمام (ع) يلفت النظر إلى ضرورة وجود هذه القاعدة الصالحة حين كان يجيب على التساؤلات التي كانت تدور في نفوس أصحابه كجوابه لسدير الصيرفي حيث جاء فيه بأنّ المطالبة بالحكم وإعلان

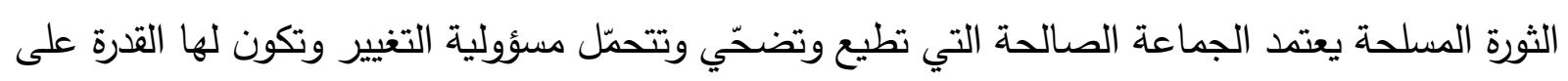

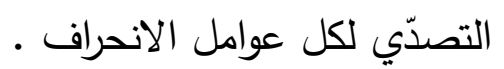

وهكذا تبدو أهمية السعي لتكوين وترشيد حركة الجماعة الصالحة في هذه المرحلة من حياة الإمام (ع)

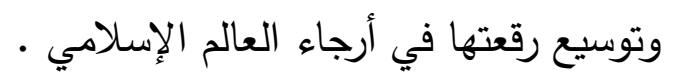

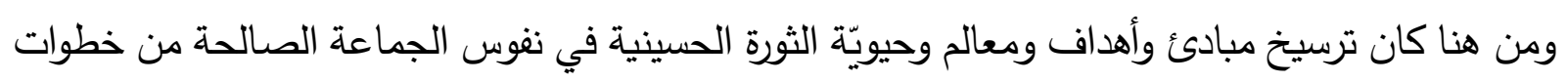

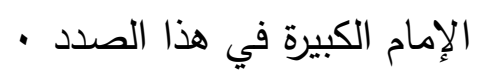

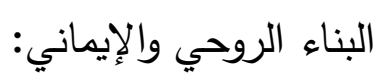

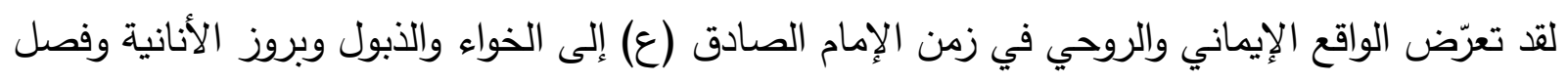

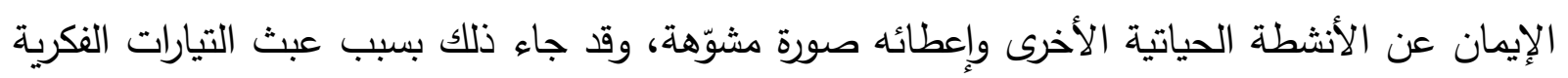
التي استندت إلى دعم السلاطين والتي كانت تؤمن هي الأخرى أيضاً بلزوم طاعة الحاكم الأموي والعباسي؛

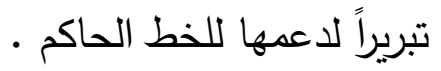
من هنا بذل الإمام نشاطاً واسعاً لاستعادة الإيمان وبناء الذات وسموّها وفق الخط القرآني وترشيح قواعد

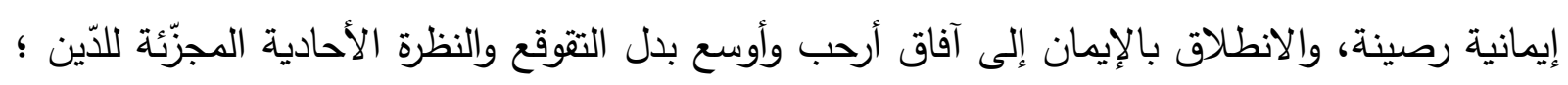

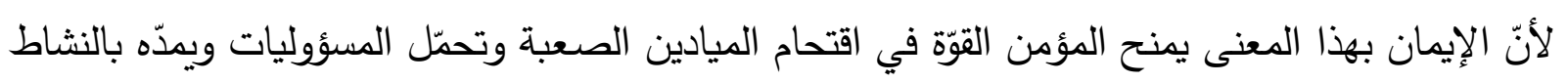
والحيوية في مواصلة العمل والجهاد . كما بيّن الإمام (ع) أنّ القلب الخالي من مخافة الله ـ التي هي معيار الكمال والقوّة لقلب المؤمن ـ ليس بشيء، فالقلب المملوء خوفاً من الله الكبير المتعال تتصاغر عنده سائر القوى مثل قوّة السلطان وقوّة المال وكل قوّة بشرية، والقلب الذي لا يستشعر الرقابة الإلهية ويتغافل عن هيمنتها يكون ضعيفاً وساقطاً مهما بدا 
قوياً وعظيماً. عن الهيثم بن واقد قال سمعت أبا عبد الله (ع) يقول: (مَن خاف الله أخاف الله منه كل شيء

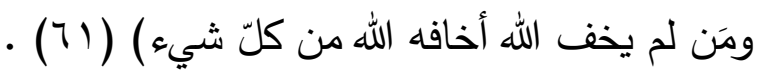
ومن الوسائل التي استخدمها الإمام (ع) في منهجه التغييري وبنائه للمجمتع الفاضل هو اهتمامه وتركيزه

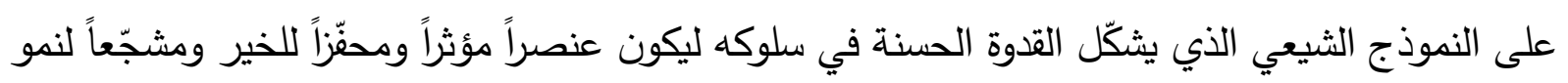

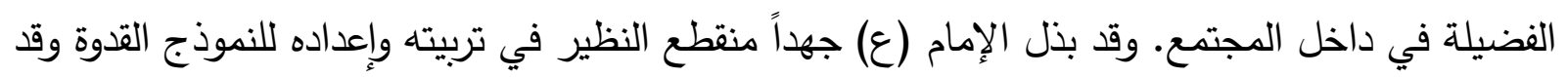
سلّحه بمختلف العلوم وأحاطه بجملة من الوصايا والتوجيهات العلمية والأخلاقية. واستطاع الإمام بطاقاته الإلهية أن يصنع عدداً كبيراً من هؤلاء الذين أصبحوا فيما بعد قادةً ومناراً تهوي والئه إليهم القلوب لتتهل من علومهم، وبقي اسمهم مخلّداً في التأريخ يتتاقل المسلمون مآثرهم جيلاً بعد جيل.

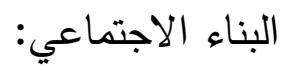
رسم الإمام الصادق (ع) الخط العام للعلاقات الاجتماعية للجماعة الصالحة، وبيّن نظامها ووضع الأسس والقواعد المبدئية لهذا النظام ورسّخها في نفوسهم؛ ليتمكّن الفرد الصالح من العيش في المجتمع وفي الظروف الصعبة، ويمتلك القدرة في مواجهة المخططات التي تسعى لتفتيت مثل البناء الذي يهدف له الإمام وهو النظام الاجتماعي الذي خطط له الإمام، وأمدّه بعناصر البقاء والاستمرار ليمتّّ بجذوره في أوساط الأمة.

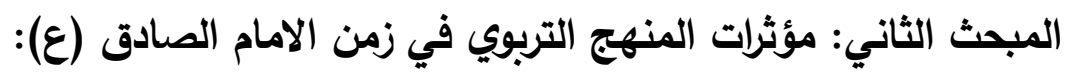
ا ـ المؤثرات التزبوية في نهاية الحكم الاموي: أدرك الامام الصادق (ع) طرفا كبيرا من العصر الأموي، وعاصر كثيرا من ملوكهم، وشاهد من حكمه التربه أعنف أشكاله، وقضى سنوات عمره الأولى حتى الحادية عشرة من عمره مع جده زين العابدين، وحتى الثانية

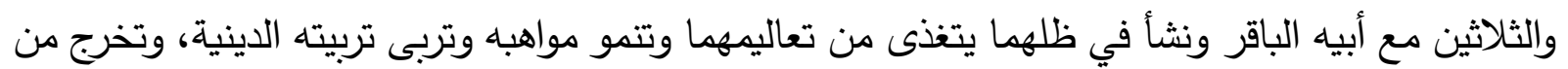

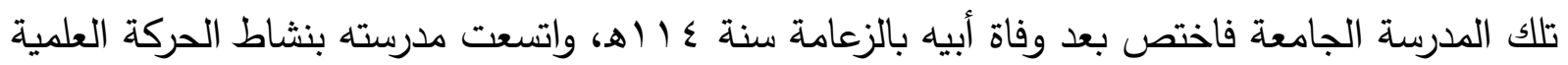
في المدينة ومكة والكوفة وغيرها من الأقطار الإسلامية. 
وقد اتسم العصر المذكور الذي عاشه الإمام بظهور الحركات الفكرية، ووفود الآراء الاعتقادية الغريبة إلى

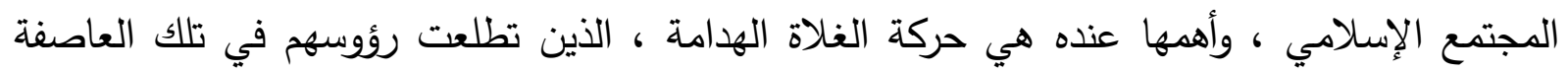
الهوجاء إلى بث روح التفرقة بين المسلمين، وترعرت بنات أفكارهم في ذلك العصر ليقوموا بمهمة الانتصار لمبادئهم التي قضى عليها الإسلام ، فقد اغتتموا الفرصة في بث تلك الآراء الفاسدة في المجتمع الإسلامي

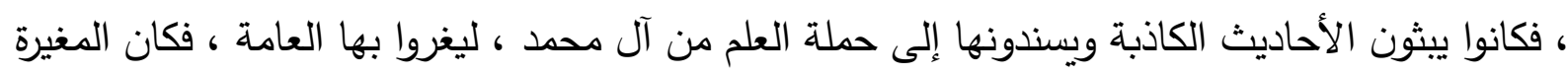

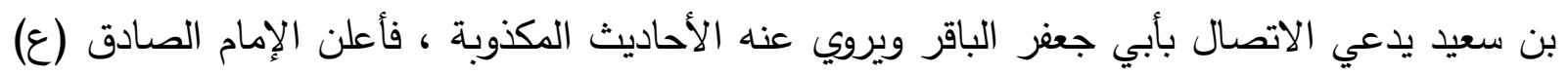

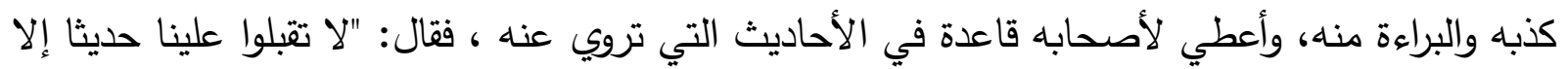
ما وافق القرآن والسنة، ثم إن الإمام قام بهداية الأمة إلى النهج الصواب في عصر لإهر تضاربت فيه الآراء

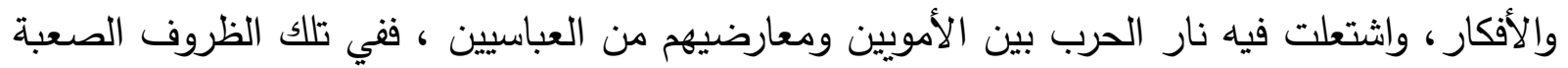

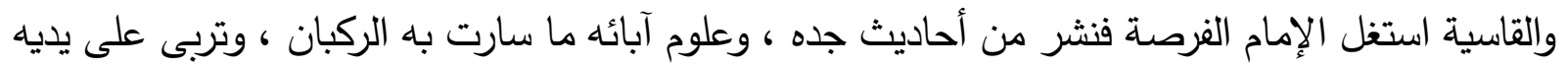

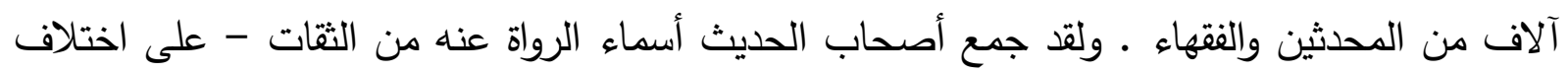
آرائهم ومقالاتهم- فكانوا أربعة آلاف رجل وهذه سمة امتاز بها الإمام الصادق عن غيره من الأئمة - (ع).

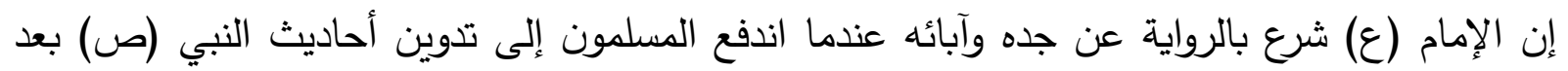
الغفلة التي استمرت إلى عام بـ إلى هـ حيث اختلط آنذاك الحديث الصحيح بالضعيف وتسربت إلى السنة ،

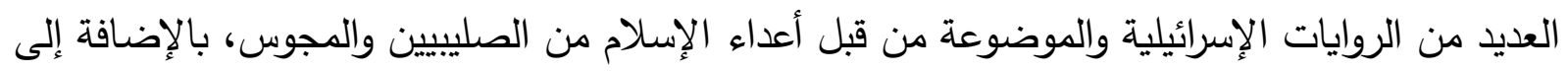
المختلقات والمجعولات على يد علماء السلطة ومرتزقة البلاط الأموي.

ومن هنا فقد وجد الإمام (ع) أن أمر السنة النبوية قد بدأ يأخذ اتجاهات خطيرة وانحرافات واضحة، فعدد (ع) للتصدي لهذه الظاهرة الخطيرة ، وتفنيد الآراء الدخيلة على الإسلام والتي تسرب الكثير منها نتيجة 
الاحتكالك الفكري والعقائدي بين المسلمين وغيرهم إن تلك الفترة كونت تحديا خطيرا لوجود السنة النبوية، وخلطا فاضحا في كثير من المعتقدات ، لذا فإن الإمام (ع) كان بحق سفينة النجاة من هذا المعترك العسر. إن علوم أهل البيت (ع) متوارثة عن جدهم المصطفى محمد (ص)، الذي أخذها عن الله تعالى بواسطة

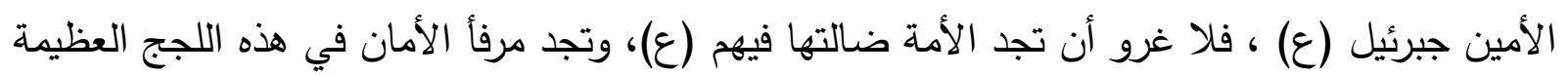

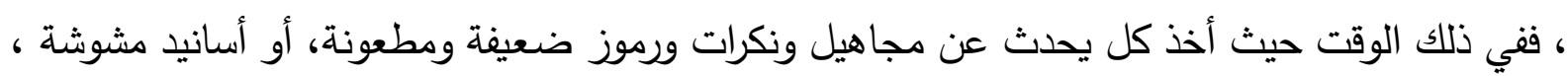
تجد أن الإمام الصادق (ع) يقول: "حديثي حديث أبي، وحديث أبي حديث جدي، وحديث جدي حديث علي بن أبي طالب، وحديث علي حديث رسول الله (ص)، وحديث رسول الله قول الله عز وجل، إن للإمام

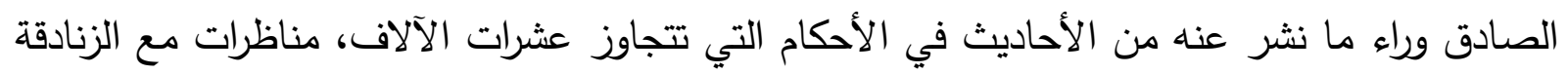

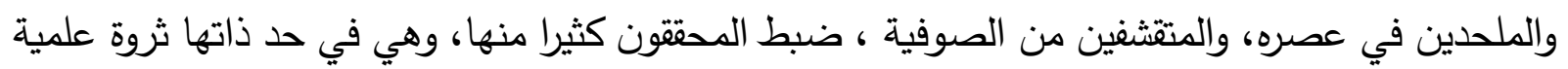

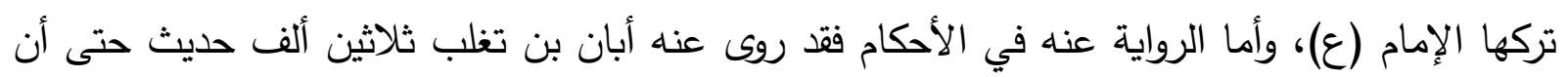

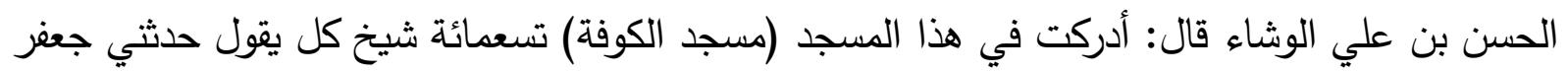
بن محمد وأما ما أثر عنه من المعارف والعقائد فحدث عنهاء ولا حرج ، ولا يسعنا نقل حتى القليل منها،

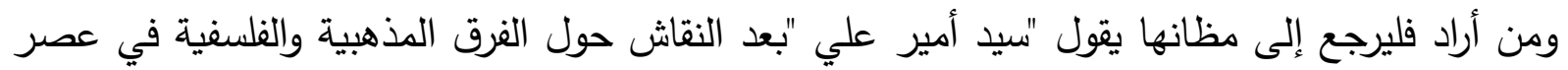
الإمام: "ولم تتخذ الآراء الدينية اتجاها فلسفيا إلا عند الفاطيين، ذلك أن أنتين انتشار العلم في ذلك الحين أطلق روح البحث والاستقصاء، وأصبحت المناقثات الفلسفية عامة في كل مجتمع من المجتمعات، والجدير بالذكر أن زعامة تلك الحركة الفكرية إنما وجدت في تلك المدرسة التي ازدهرت في المدينة، والتي أسسها حفيد علي بن أبي طالب المسمى بالإمام جعفر والملقب بالصادق، وكان رجلا بحاثة ومفكرا كبيرا جيد

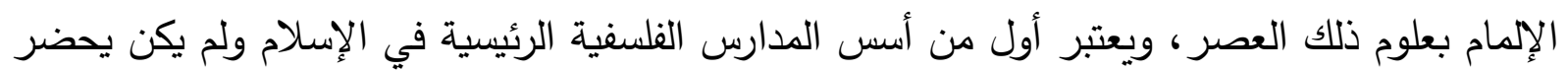
محاضراته أولئك الذين أسسوا فيما بعد المذاهب الفقهية فحسب بل كان يحضرها الفلاسفة وطلاب الفلسفة

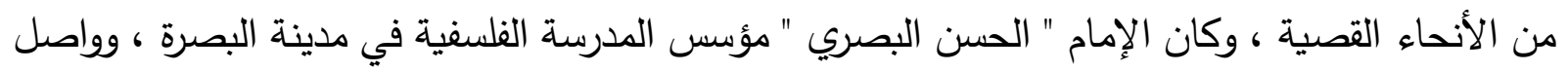


بن عطاء مؤسس مذهب المعتزلة من تلاميذه ، الذين نهلوا من معين علمه الفياض وقد عرف واصل والإمام

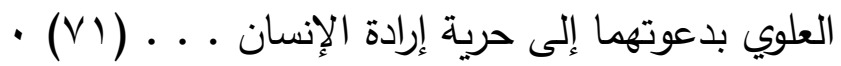
اولا :المستجدّات السياسية: لقد تداعا النظام الأموي في هذه المرحلة التاريخية من حياته بعد أن فقد في نظر الأمة كلّ مبرّراته الحضارية

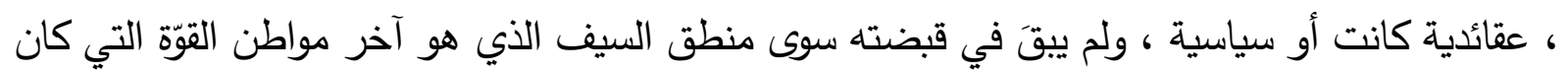
يدير بها شؤون البلاد ـ وحتى هذا المنطق لم يدم طويلاً أمام إرادة الأمة رغم صرامة آخر ملوك الأمويين (مروان) المعروف في لئ لئ حسمه . لقد استحكمت قناعة الأمة وآمنت بضرورة التخلّص من الطغيان الأموي ، ولم ييق بعد شيءٌ بيد وعّاظ

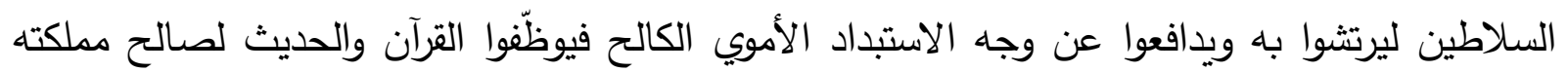
ولزوم طاعة الأمة لحكّامها ؛ حيث تراكمت في ذهن الأمة وضميرها تلك المظالم التي ارتُكبت بحق ذائ ذريّة

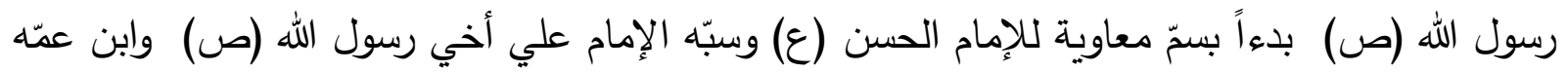
وزوج ابنته وجعل السبّ سُنّةً، ثم قتل الحسين بن علي ريحانة الرسول (ص) وأهل بيته وخيرة أصحابه بأمر الِّر

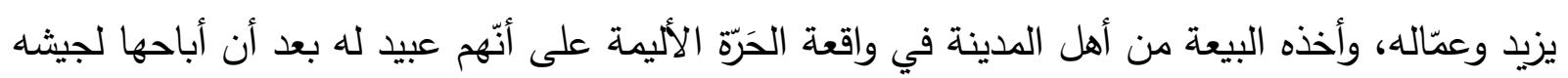
• ثلاثة أيام

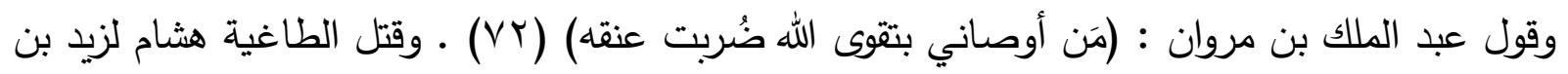

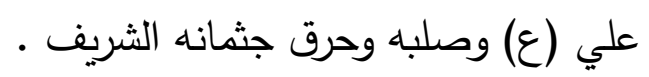
وفساد الولاة الأمويين بالإضافة إلى جبايتهم الضرائب الظالمة، وشقّ صف وحدة الأمة الإسلامية وتمزيقها

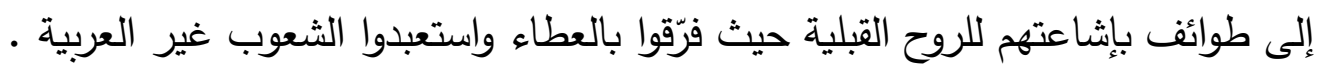


وهكذا ظهرت إلى سطح الساحة الفكرية والفقهية آراء لا ترى أية شرعية للنظام الأموي وعبّرت عن ذلك في

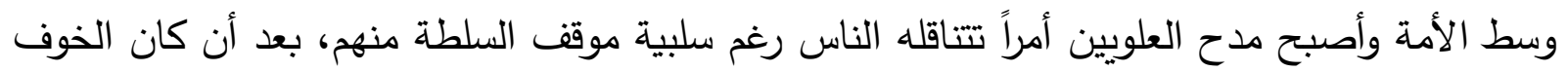
يمنعهم من التعبير عن رأيهم وهكذا استعدت الأمة بفعل تراكم الظلم الأموي؛ لأنّ تتبّلّ أي بديل من شأنه أن ينقذها من الكابوس الأموي، لعلّها تتعم بشيء من العدل والمساواة . وهذا الجو قد شجّع على ظهور اتجاهات وادّعاءات سياسية تحرض الأمة وتدعوها إلى الانضمام تحت

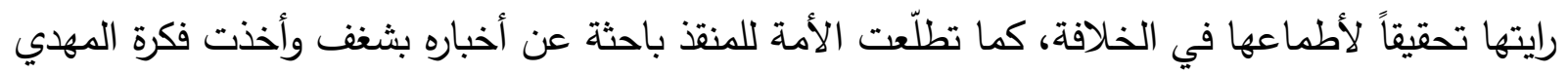
المنتظر تثقّ طريقها في أوساط الأمة المظلومة. ومن جانب آخر اتّّع خط الإمام (ع) وامتّّ وكثرت أنصاره واستلهمت الأمة ثقافته حيث إنّه قد أثّر في

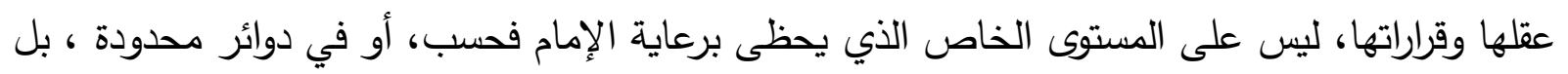

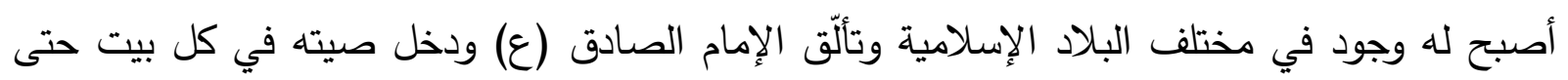
أصبح مرجعاً روحياً تهوى إليه القلوب من كل مكان وتلوذ به لحل مشكلاتها الفكرية والعقائدية والسياسية.

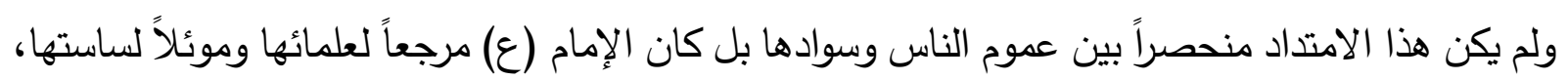
فهذا سفيان الثوري يقول: دخلت على الإمام الصادق (ع) فقلت له: أوصني بوصيّة أحفظها من بعدك.

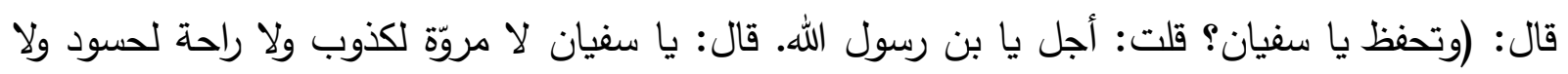

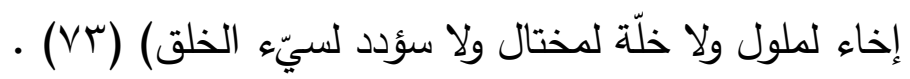

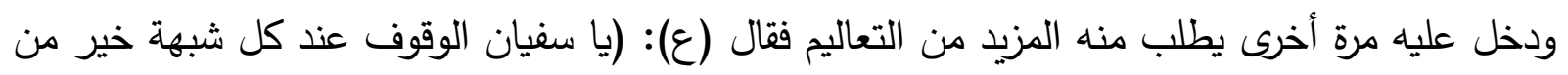

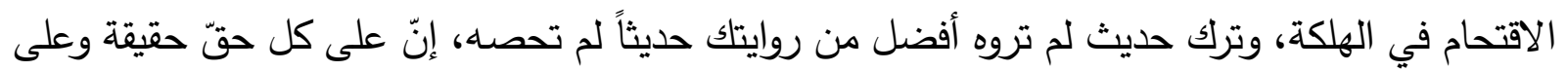

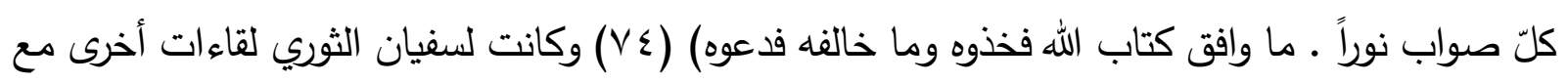

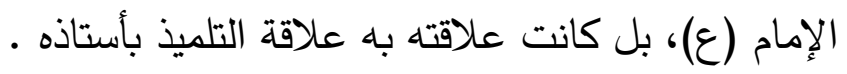


وكان من جملة العلماء الذين يدخلون على الإمام للاستفادة منه: حفص بن غياث وهو أحد أعلام عصره

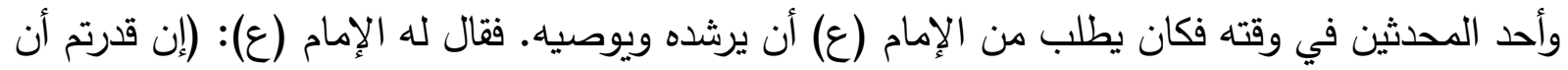

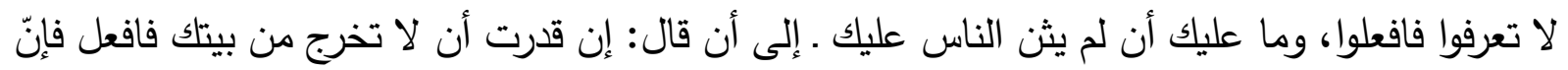
عليك في خروجك أن لا تغتاب، ولا تكذب ولا تحسد، ولا ترائي، ولا تداهن) .

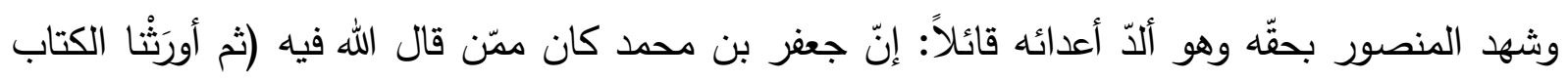

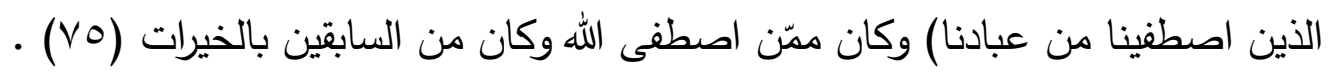

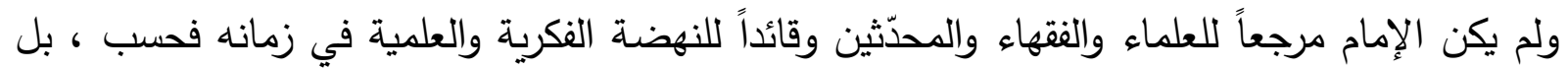

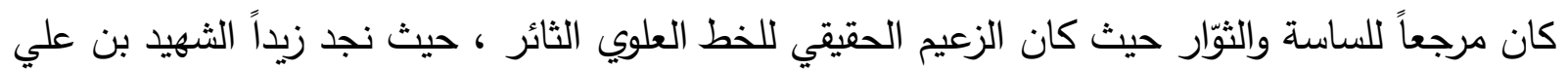
بن الحسين عليهماالسلام يرجع إليه في قضية الثورة ، كما كان زيد يقول بحق الإمام (ع) في كل زمان

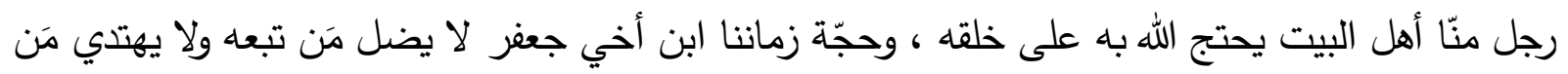

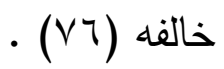
ثانيا : الانحراف الفكريّ والعقائديّ:

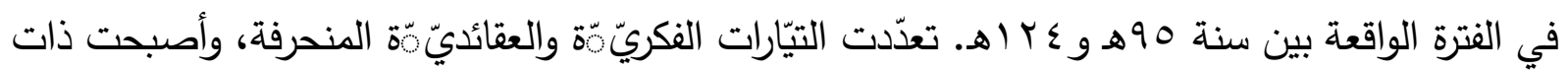
أتباع وأنصار، وتحوّلت إلى كيانات ذات إفرازات سياسيّة خالف الكثير منها الأسس الواضحة فئه في العقيدة الإسلاميّة، فانتشرت أفكار الجبر والتفويض والإرجاء والتجسيم وتثبيه الله تعالى بخلقه. وتعدّدت تيّّارات

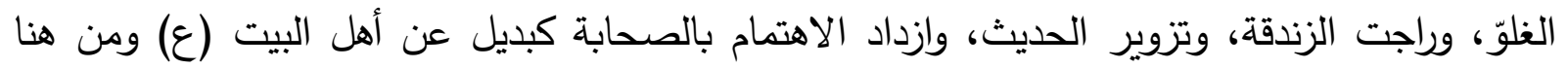

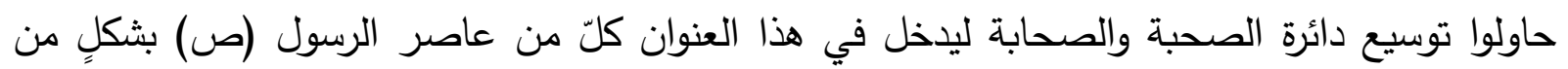
الأشكال وإن لم يتأثّر بثقافته وروحه. وقد وصف الإمام الرضا (ع) دور دور الحكّام في عملية التزوير للحديث

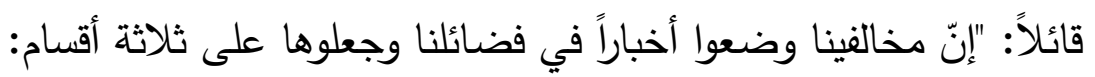

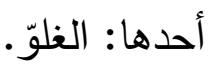


وثانيها: التقصير في أمرنا.

وثالثها: التصريح بمثالب أعدائنا

ثالثا : الانحراف السياسيّ:

حوّل الأمويّون الخلافة إلى ملك يتوارثه الأبناء عن الآباء، واستبدّوا بالأمر فلا شورى ولا استشارة إلّا للمنحرفين والفسّاق.

أمّا بالنسبة إلى حكّامهم والسياسة الّتي اتّبعوها فكانت على الثكل التالي:

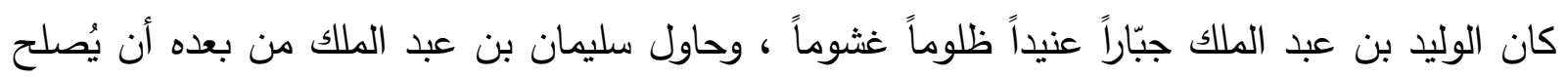

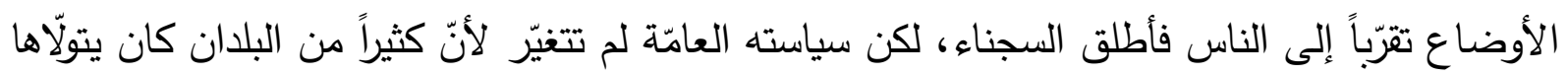

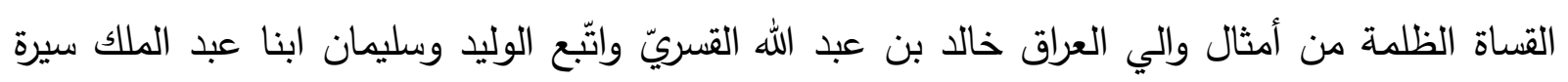
أبيهما في قتل الرافضين للبيعة لهما.

وحينما تولّى عمر بن عبد العزيز الحكم اتِّذ سياسة جديدة تخالف من سبقه، فقام ببعض الإصلاحات

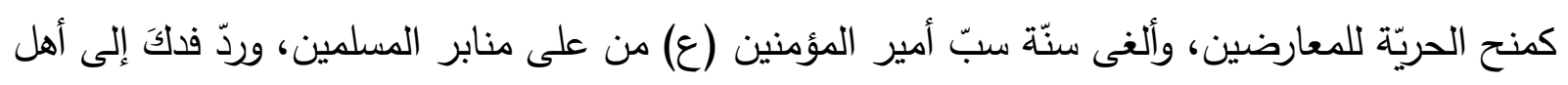

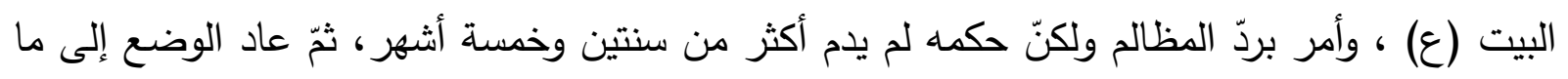

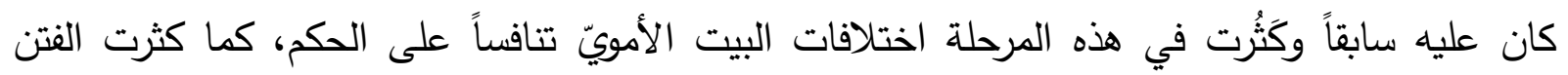

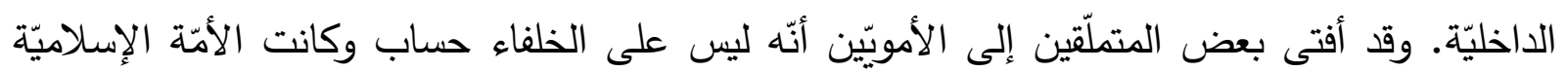

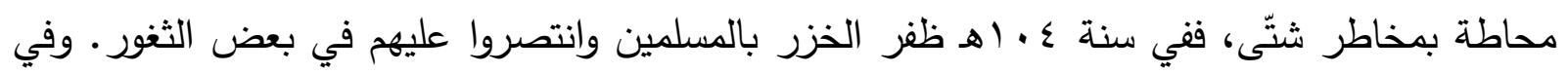

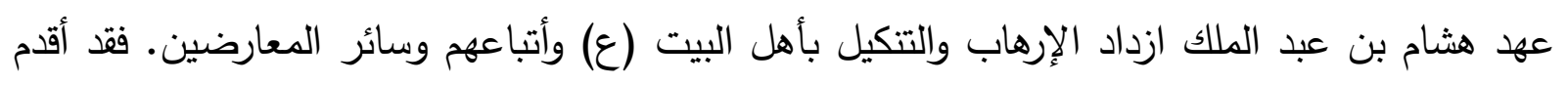

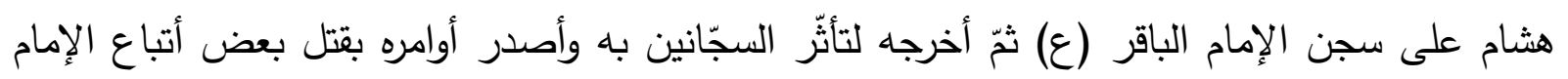
الباقر (ع) إلّا أنّ الإمام (ع) استطاع أن ينقذهم من القتل حيث استفادوا من أسلوب التقيّة الّذي أرشدهم

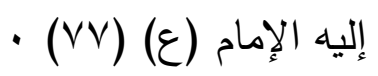


رابعا : الانحراف الاجتماعيّ والأخلاقيّ:

حوّل الأمويّون الأنظار إلى الغزوات وفتح البلاد طلباً للغنائم وإبعاداً للمعارضين وأدّى التوسّع في غزو الإدي

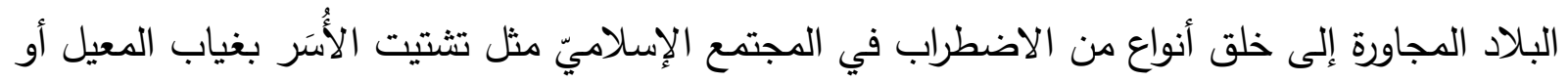

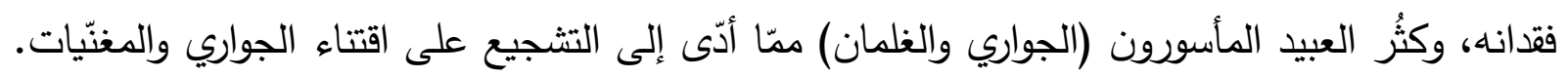

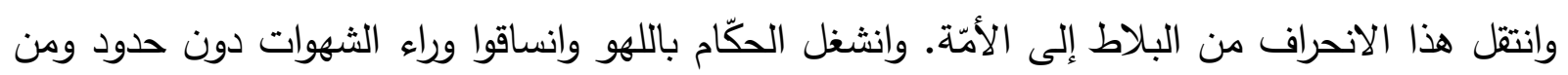
هنا تطوّرت ظاهرة الغزل والتشبيب بالنساء في العهد الأمويّ كما يُفصح عن ذلك تأريخ الأدب العربيّ والتي خامسا :الانهيار الاقتصاديّ: خالف الأمويّون الأسس الثابتة للنظام الاقتصاديّة الإسلاميّ الّتي تتصّ على أنّ الأموال هي أمانة الله عند

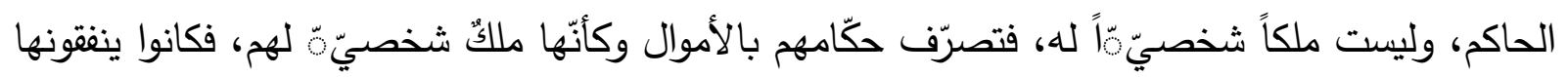
حسب رغباتهم وأهوائهم، وبالأخصّ على ملذّاتهم. وكان للجواري والمغنيّن نصيب كبير في بيت المال، كما كانوا ينفقون الأموال لشراء الذمم والضمائر ويمنحونها لمن يشترك في تتبيت سلطانيت مانهم أو مدحهم والثناء

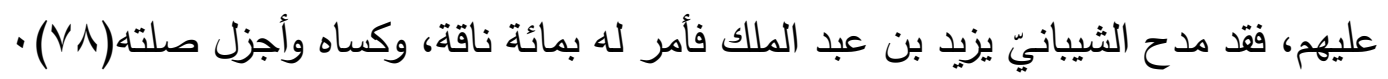
وكان الحكّام يعيشون في أعلى مراتب الترف والبذخ، ويبذّرون أموال المسلمين على شهواتهم، وعلى المقرّبين لهم، في وقت كان يعيش فيه كثير من الناس حياة الفقر والجوع والحرمان.

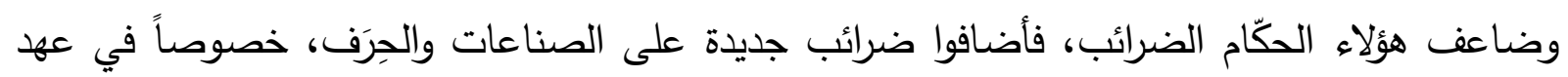

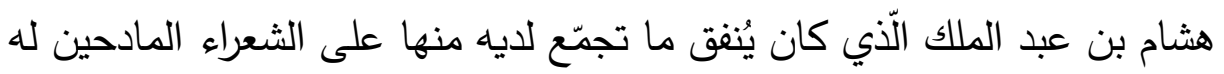

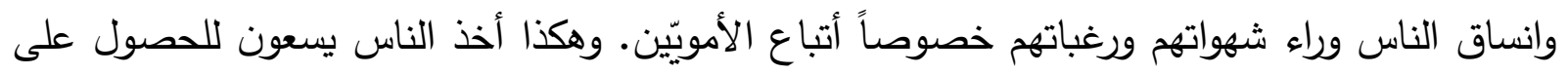

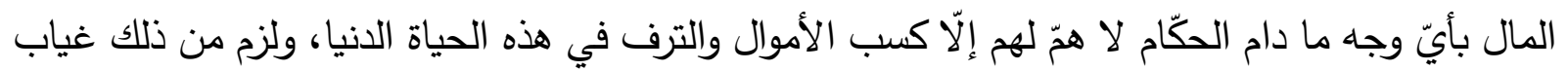

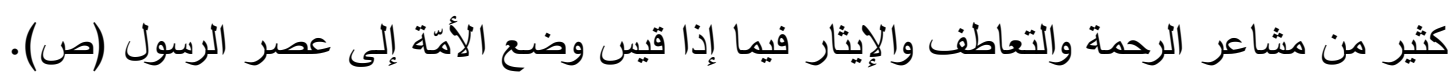

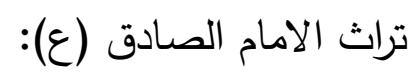


خير ما نختتم به بحثنا المتواضع هو التحدث عن تراث سيدنا وامامنا الصادق (ع) وذلك عن طريق درج خصائص جامعته التربوية والعلمية وكما يلي:

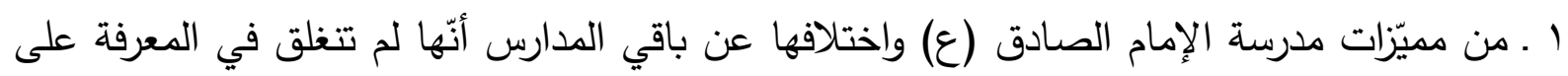

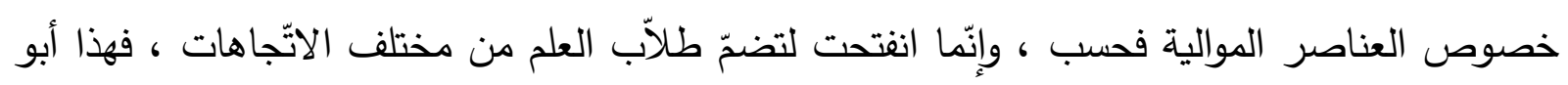

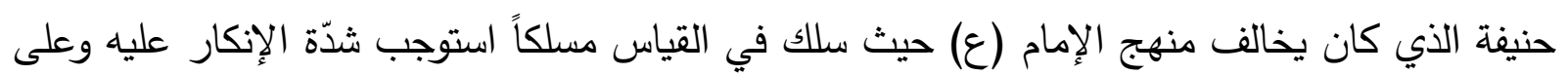

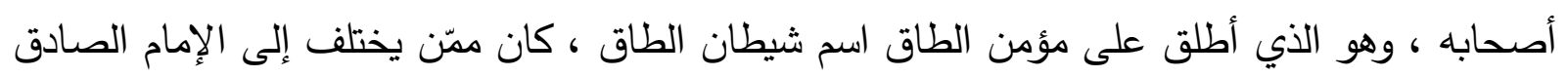

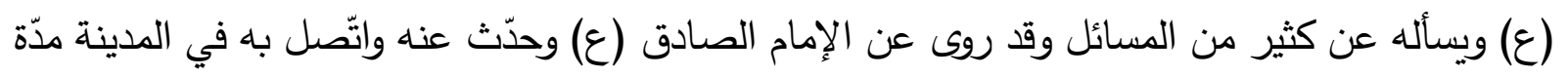

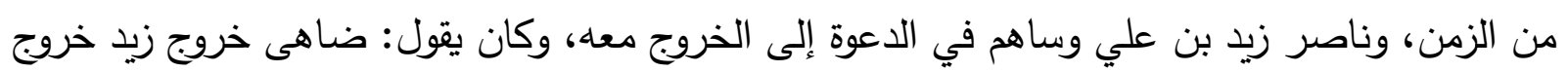
رسول الله (ص) يوم بدر، وناصن r ـ انفتحت مدرسة الإمام (ع) على مختلف فروع المعرفة الإسلامية والإنسانية، فاهتّّت بالقرآن والسنّة

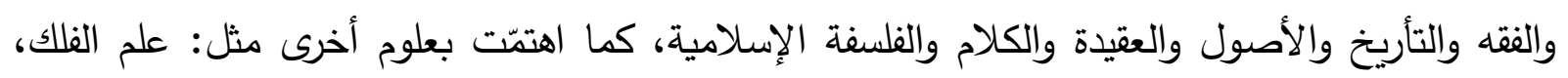

$$
\text { والطبّ، والحيوان، والنبات، والكيمياء، والثيزياء ( } 9 \text { و). }
$$

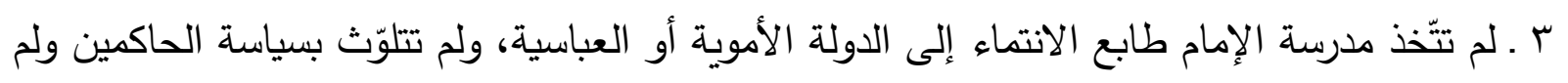

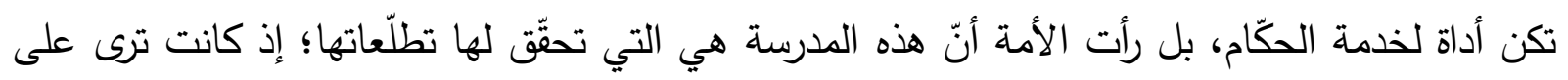

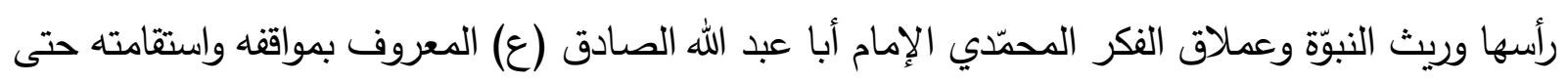
لقّب بالصادق لسموّ أخلاقه وعدم مساومته وخضوعها لسياسة الحكّام المنحرفين.

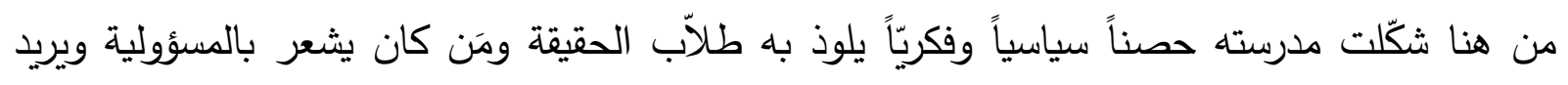
التخلّص من التيه الذي خلّفته التيارات الفكرية والسياسية المتضاربة في أهدافها ومساراتها. 
ـ ـ وتميّزت أيضاً جامعة الإمام الصادق (ع) بمنهجها السليم وعمقها الفكري، ولم تكن أطروحتها في الإعداد العلمي مبتنية على حشو الذهن، وإنّما كانت تعتمد الفكر والتعمّق والأصالة ونموّ الكفاءات العلمية ، وتعتبرها

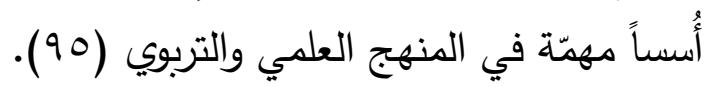
ه ـ أنتجت هذه الجامعة رموزاً للعلم والتقوى والاستقامة، وعرفت بالعطاء العلمي والديني للأمة وبما أبدعته

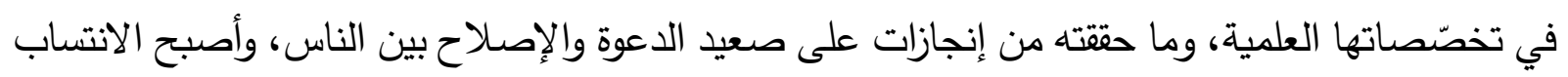

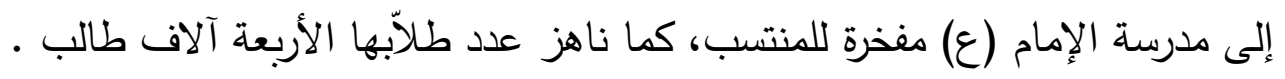

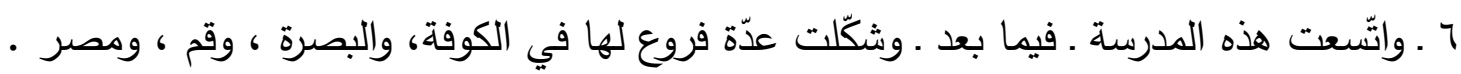

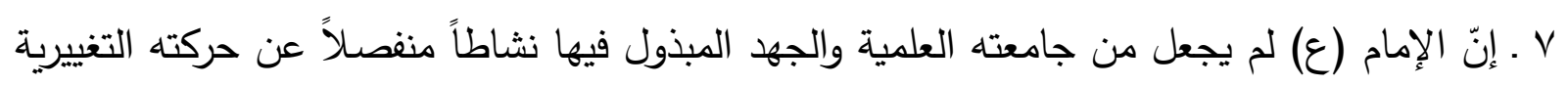

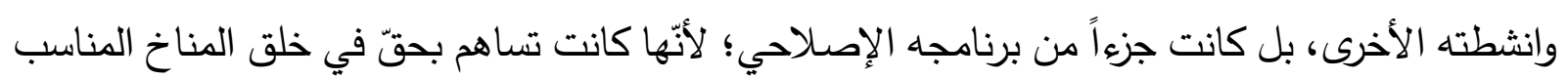

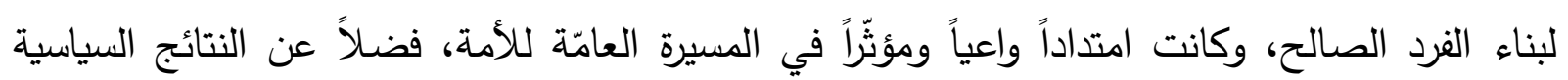
الايجابية الخاصّة، حيث نجد الكادر العلمي الحاضر في مدرسة الإمام (ع) هو نفسه الذي يحضر في وني فئري نشاطات الإمام الخاصّة. A ـ تميّزت مدرسة الإمام الصادق (ع) بالارتباط المباشر بمصادر التشريع والمعرفة وهما الكتاب الكريم والسنّة النبوية الشريفة بنحو لا مثيل له. ومن هنا حرص الإمام الصادق (ع) على أن يحقّق من خلال مدرسته إنجازاً بخصوص تدوين الحديث

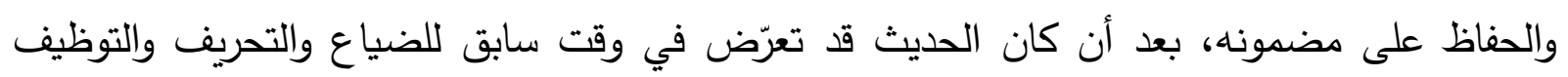

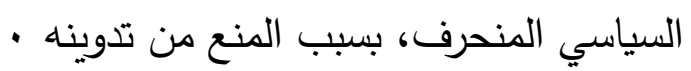
بينما كان الهدف البعيد من منع تدوين الحديث هو تغييب الحديث النبوي الذي كان يؤكّد ربط الأمة بأهل البيت (ع) فاستهدف الحكّام صرف الناس عن أهل البيت (ع)؛ لأنّ الحديث حين كان يؤكّد الارتباط بهر تهري كان يحول بينهم وبين الانسياق وراء كلّ ناعق سياسي أو حاكم جائر . 
يقول الإمام الصادق (ع): ( .. أما والله إنّ عندنا ما لا نحتاج إلى أحد والناس يحتاجون إلينا. إنّ عندنا الكتاب بإملاء رسول الله (ص)، وخطّه علي بيده صحيفة طولها سبعون ذراعاً فيها كل حلال وحرام).

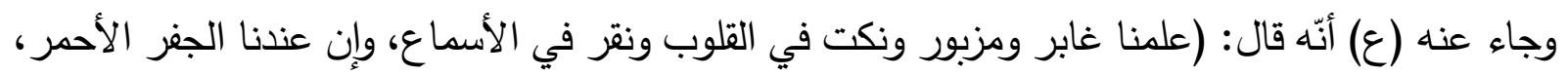

والجفر الأبيض، ومصحف فاطمة (ع) وإن عندنا الجامعة فيها جميع ما يحتاج الناس إليه) (79 (9) . 9 ـ وتميّزت أيضاً مدرسة الإمام (ع) بالاهتمام بالتدوين بثكل عام، بل ومدارسة العلم لإنمائه وإثرائه .

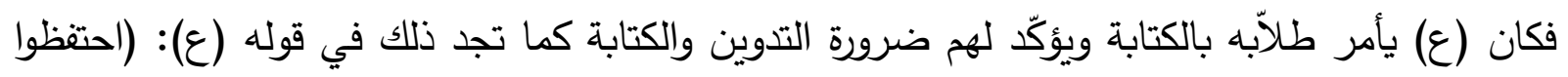

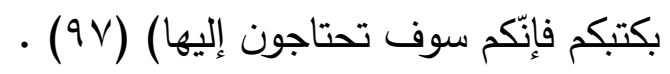
الخاتمة:

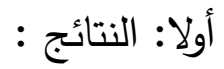
ا.يبقى الفكر الإسلامي الذي تحمله مدرسة أهل البيت (ع) يحمل الصفاء والأصالة وقد وجدت الباحثة أن الصحيفة السجادية تحمل الأمانة للرسالة النبوية وتصونها والرجوع اليها يُعدُّ رجوعاً إلى الينابيع الأصيلة والنقية . r.لقد كان الإمام يبحث في المضامين الراقية سواء في المجال الفكري ،أم التربوي، أم ألسياسي ، أم الاجتماعي ، أم الأخلاقي ، ويستكثف المفاهيم والنظريات ، والآراء الثديدة ،هما أغني ولا شكَّ مسيرة

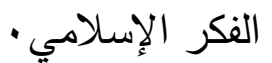
r.تميز الإمام الصادق (ع) بتربية روحية من خلال حياته المباركة ونستفيد من الدروس الروحية التي تضيء

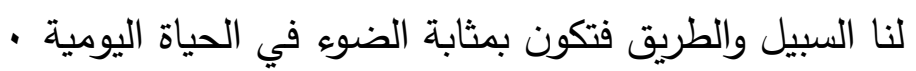

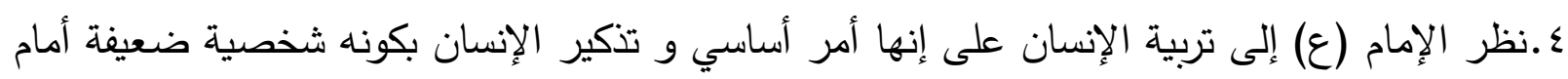

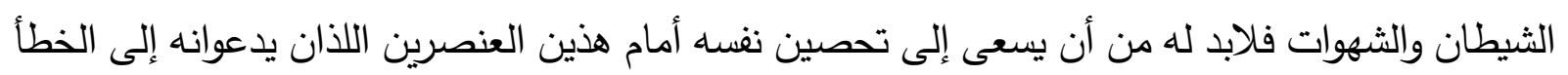


وهو بهذا كأنه يريد أن يشير إليه بأنك ترتكب الخطأ فينبغي عليك أن تعمد إلى تحصين نفسك مقابله بحيث

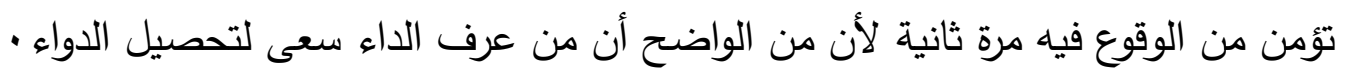

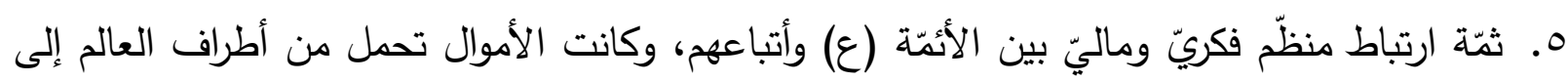

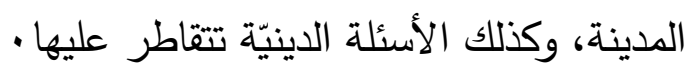

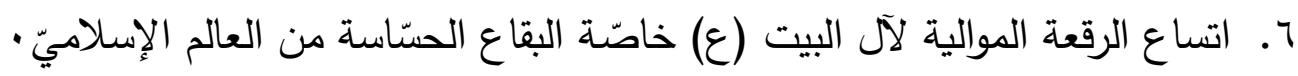

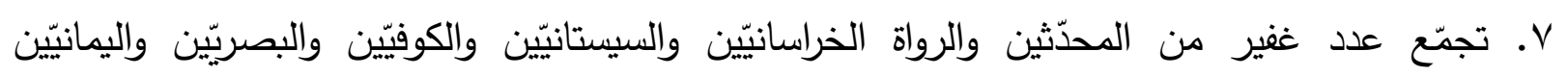
والمصريّين حول الإمام.

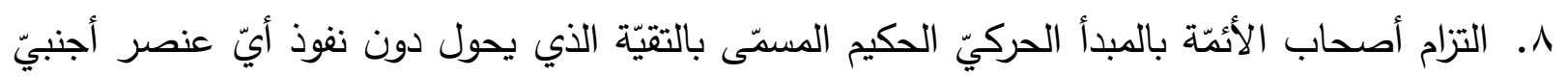

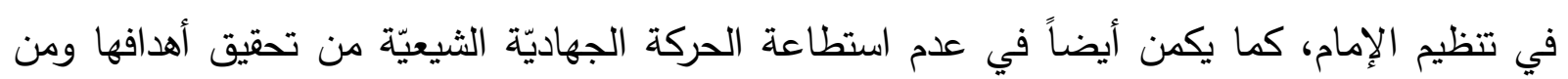

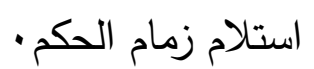

9. انتشرت في هذه المدة عقائد خاطئة واتجاهات منحرفة من الالحاد والزندقة ذات أصحاب تدافع عنها ولم تكن وليد هذا الظرف بالذات وإنما نشطت في هذا الجو حيث كان بعض الخلفاء يتبنى بعضاً منها ويسح لانتشار البعض الأخر.

• ا. ظهور الكثير من القرق والتيارات المنحرفة مما جعل الادعياء وهواة الرذيلة والذين زاد نشاطهم وشاع

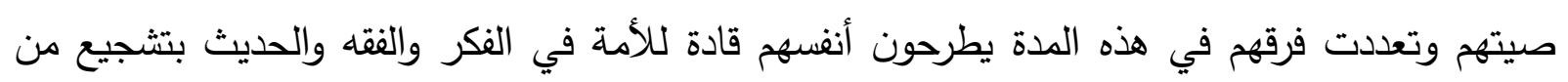
المنصور ومن تلك الفرق القدرية، والزيدية، والمعتزلة، والخوارج.

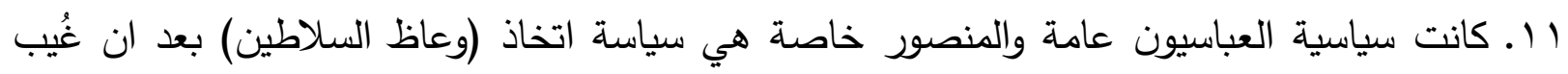
الامام الكاظم (ع) عن المسرح السياسي والفكري وهي سياسية بديل يرعاه الخليفة ويدعمه بما اوتي من قوة

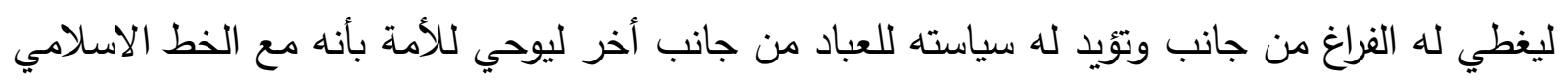

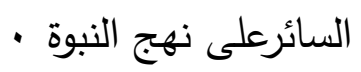


r ا ـ شددت السلطة المراقبة على الثيعة بعد استثهاد الإمام الصادق (ع) وعم الارتباك أوساطهم وشحنت الصاط

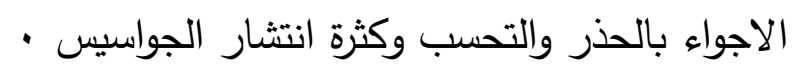
التوصيات:

من خلال ما بحثنا عن الفكر التربوي لامام الامة وقائدها مؤسس المذهب الجعفري الامام الصادق ع ندرج

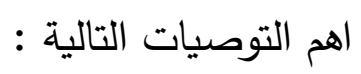

ا ـ السير باتجاه وخطى الامام الصادق (ع) وكما رسمه الينا من خلال جامعته العلمية العملاقة .

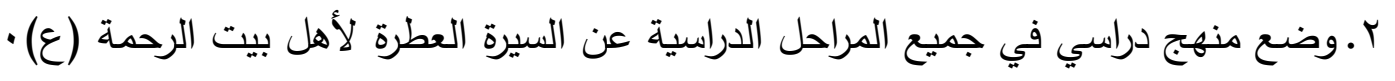
r. نشر فكر اهل البيت وبصورة مستمرة من خلال القاء المحاضرات والخطب سواء في الجوامع والحسينايات

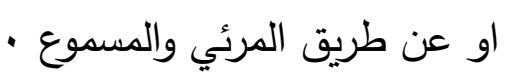
ـ ـتدريب وتوجيه عدد كثير من المحدثين عن فضائل وعلوم اهل البيت (ع) في شتى قاع العالم. ه. الرجوع الى احكامهم واستلالهم في جميع قضايا المجتمع وخصوصا الفقهية منها وجعله قانونا ثابتا لاسيما في المحاكم الثرعية العراقية.

الهوامش:

1- ابن الصباغ المالكي، الفصول المهمة، صبو 19

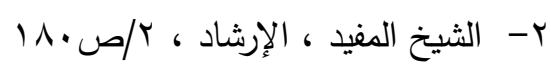

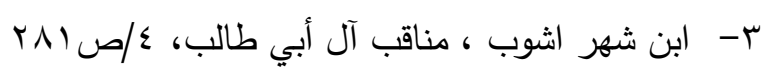

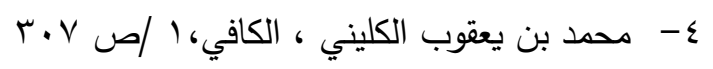

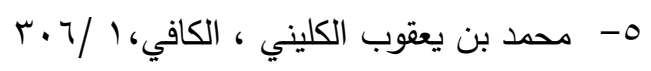

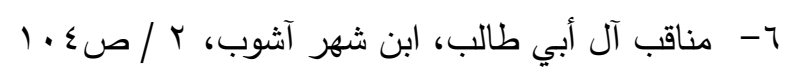

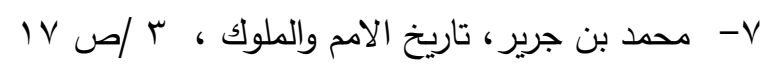

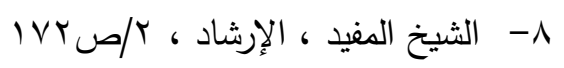




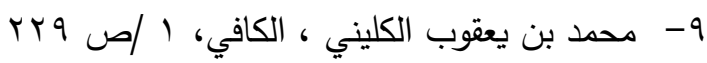

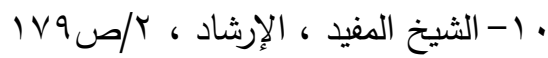

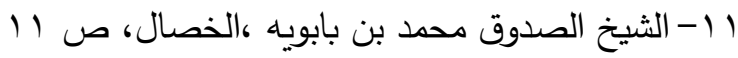

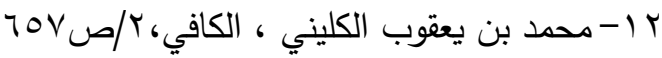
با - الثيخ الصدوق ، الخصال، ص 9 ؛

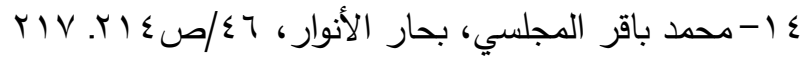

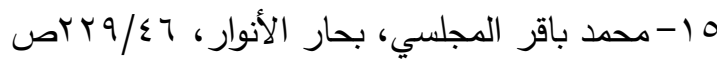

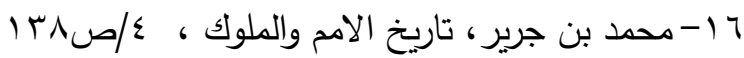

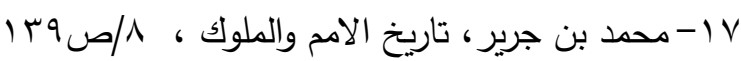

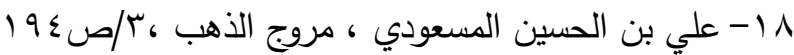

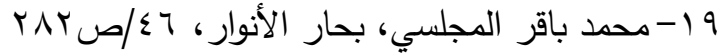

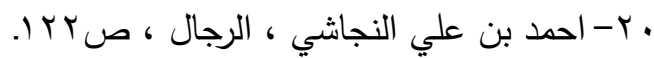

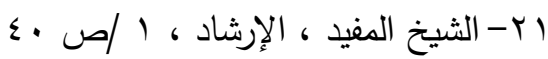

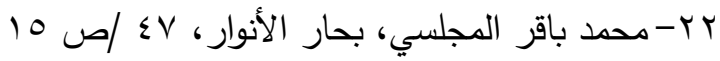
r

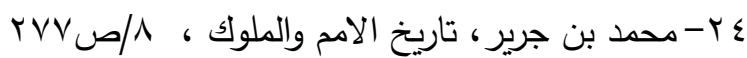

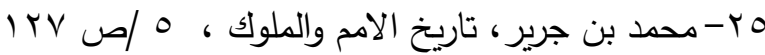

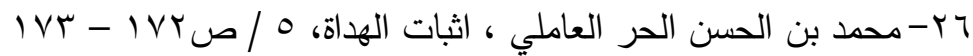

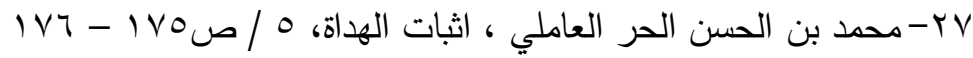

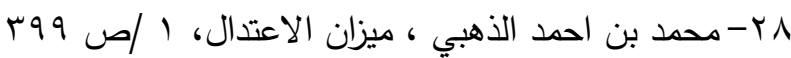

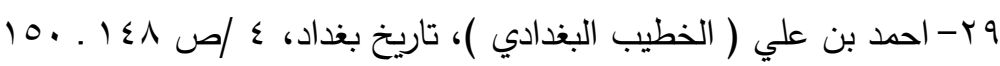
. ب-سورة الزمر ، الآية

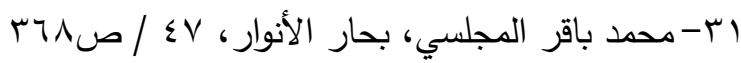

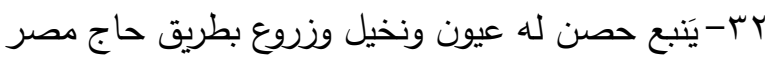


بr- الجدي ، من أولاد المعز

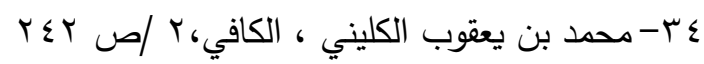

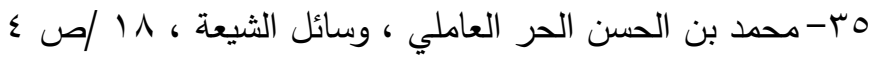

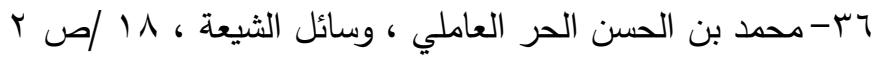

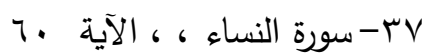

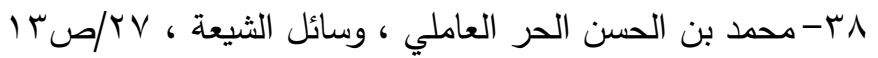

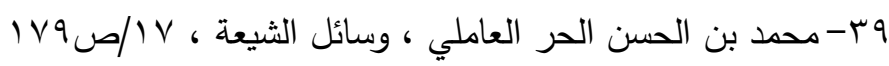

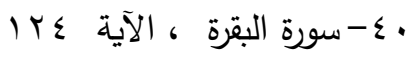

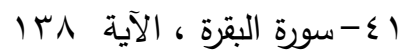

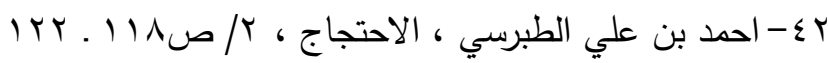

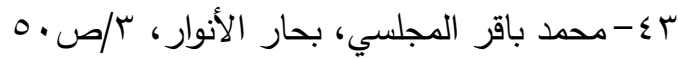

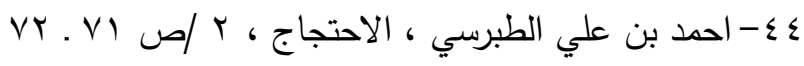

0

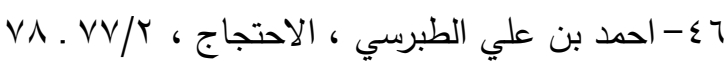

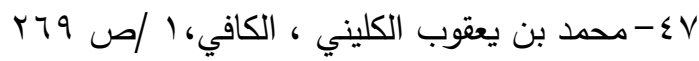

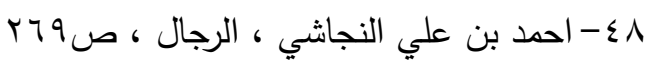

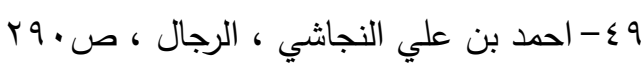

• - -والإمام (ع) هنا في مقام نفي العلم بالغيب الاستقلالي الذي يدّعيه الغلاة ، لا العلم بالغيب الممنوح للنبي (ص) ولهم

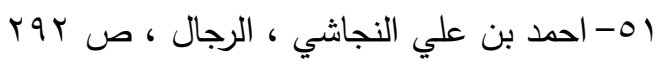

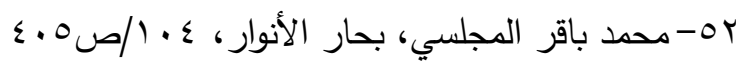

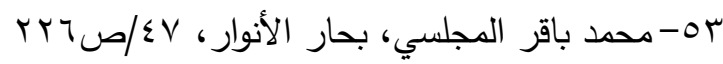

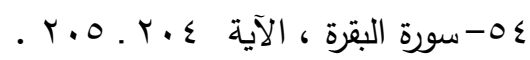

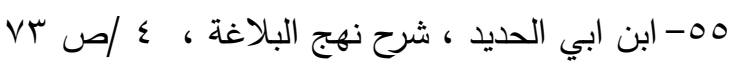




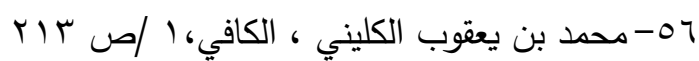

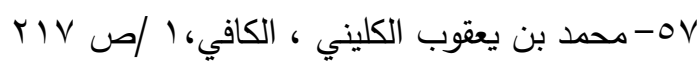

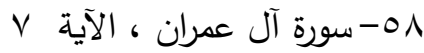

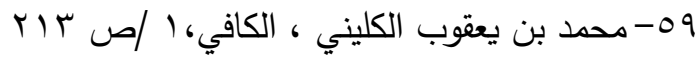

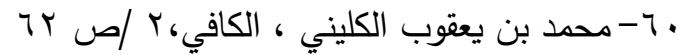

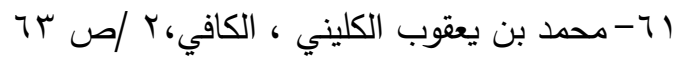

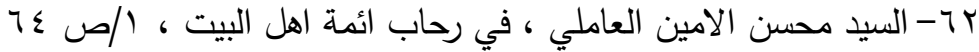

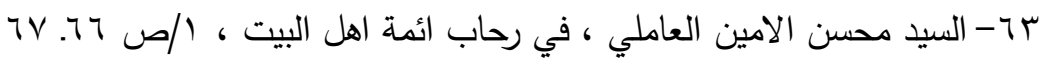

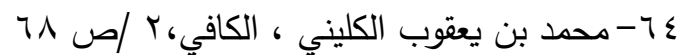

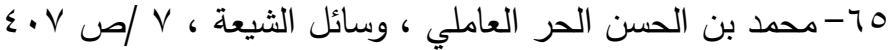

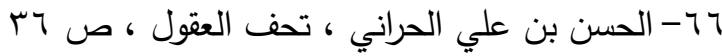

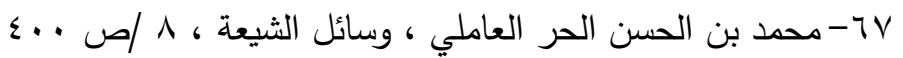

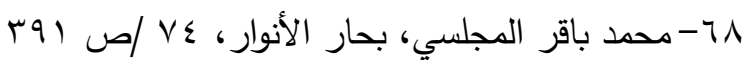

9 7- السخيمة ، الحقد والضغينة حتى تسل سخيمته والسل الانتزاع والإخراج في رفق الق

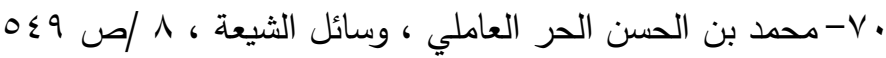

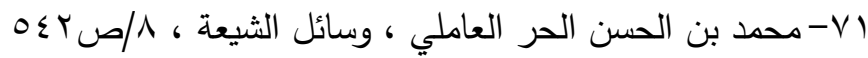

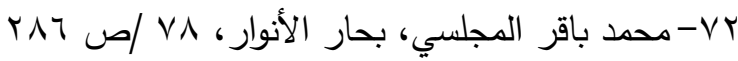

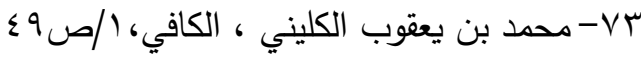

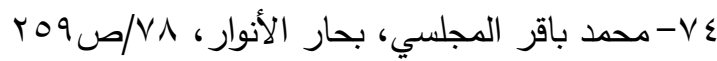

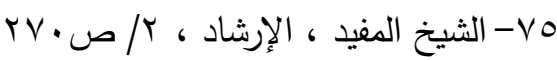

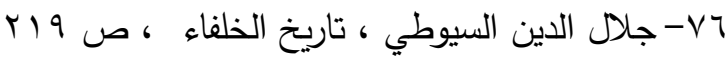

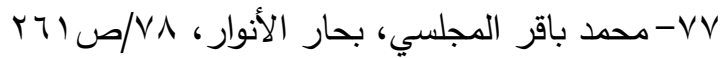

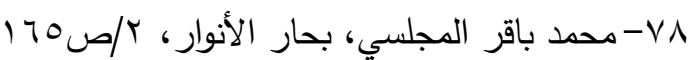

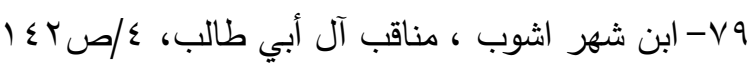


. ابن شهر اشوب ، مناقب آل أبي طالب، ؟/ص99

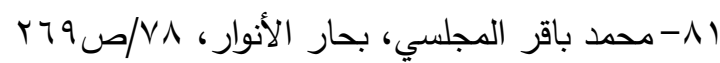

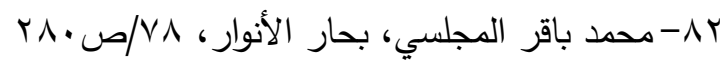

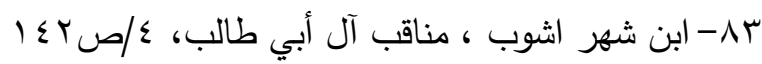

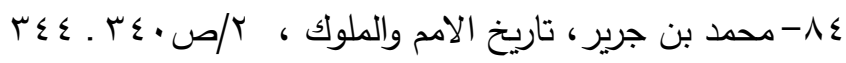

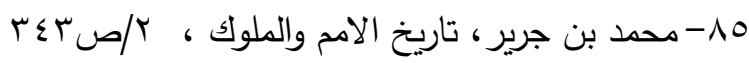

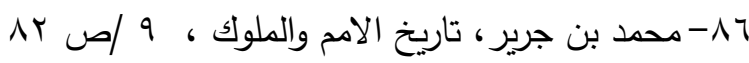

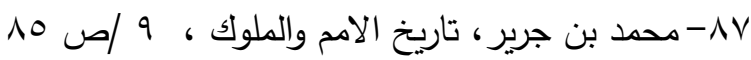

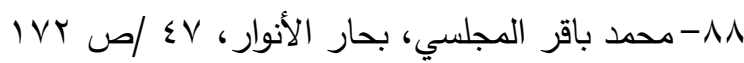

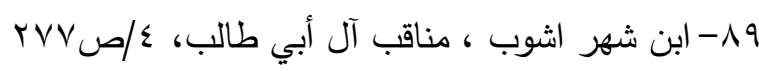

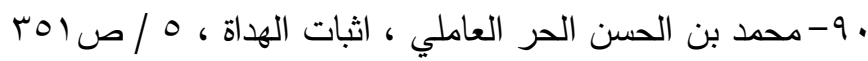

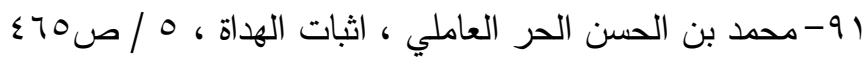

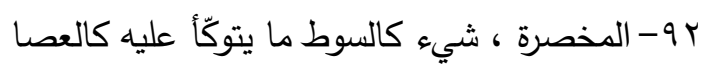

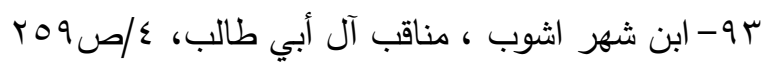

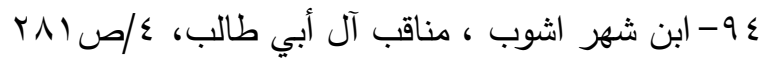

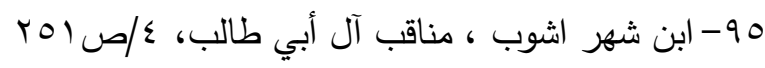

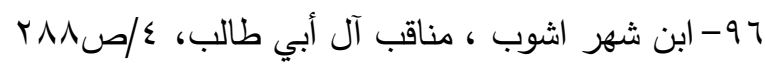

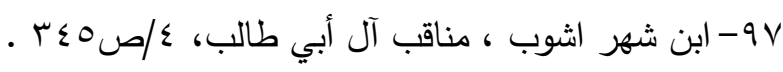

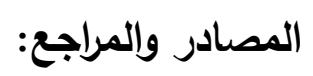

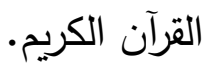

ا ـ اثبات الهداة: الحر العاملي: محمد بن الحسن (م ع ـ 11 هجري) المطبعة العلمية، قم المقدسة.

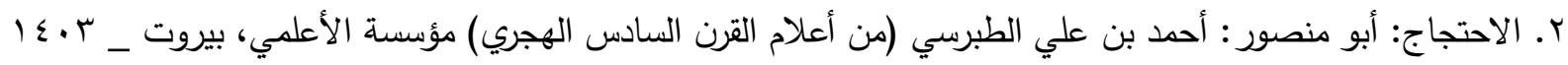
هجري.

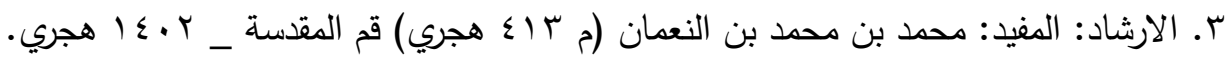




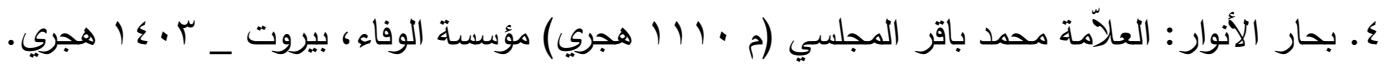
ه. تاريخ بغداد: الخطيب البغدادي: أحمد بن علي ( م سج؛ هجري) المكتبة السلفية، المدينة المنورة.

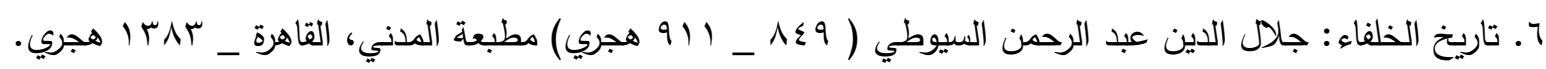
V. تاريخ الطبري المستّى (تاريخ الأمم والملوك): محمد بن جرير (م • اس هجري) مؤسسة الأعلمي، بيروت.

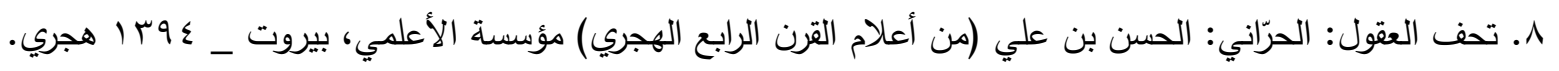

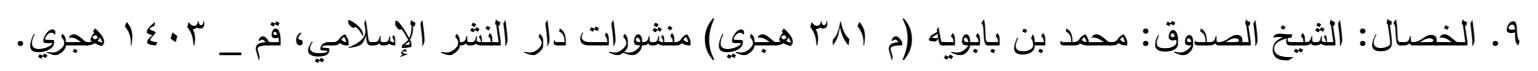

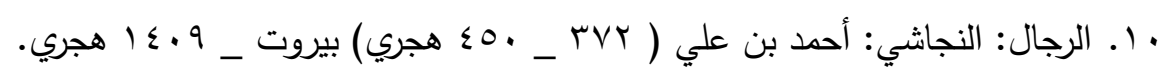

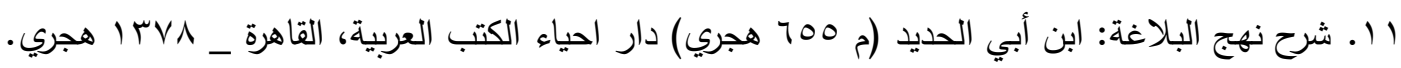

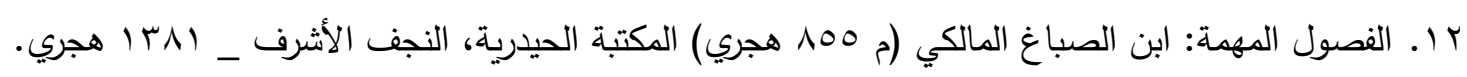

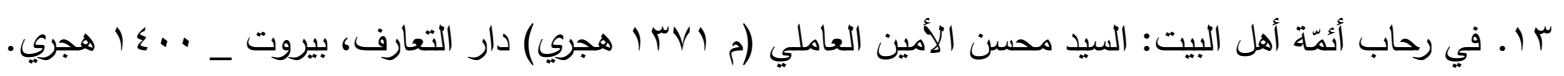

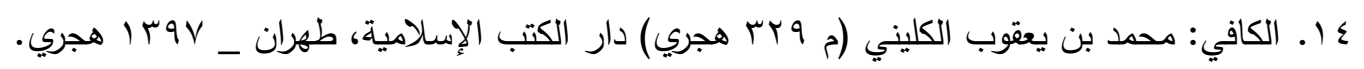

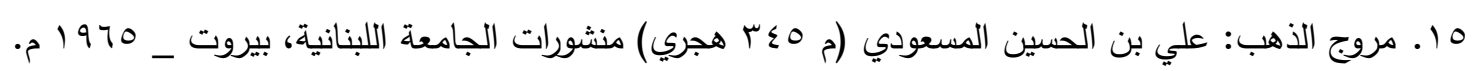

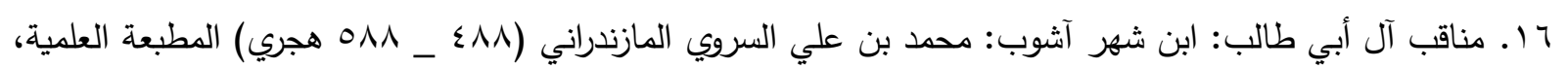
قم المقدسة. 
